\title{
Chlorination of Magnesium Carbonate in a Stirred Tank Reactor
}

\author{
by \\ Mark William Kennedy \\ Department of Mining and Metallurgical Engineering \\ McGill University \\ Montreal, Canada
}

June, 1996

A thesis submitted to the Faculty of Graduate Studies and

Research in partial fulfillment of the requirements for the degree of Master of Engineering

OM.W. Kennedy 1996 
The author has granted an irrevocable non-exclusive licence allowing the National Library of Canada to reproduce, loan, distribute or sell copies of his/her thesis by any means and in any form or format, making this thesis available to interested persons.

The author retains ownership of the copyright in his/her thesis. Neither the thesis nor substantial extracts from it may be printed or otherwise reproduced without his/her pelmission.
L'auteur a accordé une licence irrévocable et non exclusive permettant à la Bibliothèque nationale du Canada de reproduire, prêter, distribuer ou vendre des copies de sa thèse de quelque manière et sous quelque forme que ce soit pour mettre des exemplaires de cette thèse à la disposition des personnes intéressées.

L'auteur conserve la propriété du droit d'auteur qui protège sa thèse. Ni la thèse ni des extraits substantiels de celle-ci ne doivent être imprimés ou autrement reproduits sans son autorisation.

ISBN $\quad 0-612-19871-5$ 


\begin{abstract}
A study was conducted on the reaction of solid $\mathrm{MgO}$ formed from magnesite ( $\mathrm{MgCO}$ ). with $\mathrm{Cl}_{2}$ and $\mathrm{CO}$ gas. in a stirred tank reactor containing a liquid bath of $\mathrm{MgCl}$. The reaction rate was found to be controlled by CO mass transfer from the gas to the liquid phase and was zero order with respect to the concentration of MgO. At temperatures from 743 to $824^{\circ} \mathrm{C}$. the reaction rate exhibited an activation erergy of $80 \mathrm{~kJ} / \mathrm{mol}$. which is typical of a diffusion controlled reaction.
\end{abstract}

The chlorination rate was effected by both temperature and $\mathrm{CO} / \mathrm{Cl}_{2}$ ratio and estimates of the optimum conditions were obtained: temperature $\left(\$ 56.6^{\circ} \mathrm{C}\right)$ and ratio of $\mathrm{CO} / \mathrm{Cl}$, (1.24). The addition of an incrt gas $\left(\mathrm{N}_{2}\right)$ to the reagent mixture was found to decrease the reaction rate. Iron was found to have a negligible effect on reaction rate at the levels tested (up to 560 P.P.M.).

For those experiments conducted at $820^{\circ} \mathrm{C} \pm 5^{\circ} \mathrm{C}$. an overall correlation was obtained which related the $\mathrm{MgO}$ reaction rate, with impeller power $\left(\mathrm{kW} / \mathrm{m}^{3}\right)$. superficial gas velocity $(\mathrm{cm} / \mathrm{s})$ and the partial pressure of $\mathrm{CO}(\mathrm{atm}$.$) :$

$$
\text { Rate }=0.609\left(\mathrm{P}_{\mathrm{k}} / \mathrm{V}_{\mathrm{l}}\right)^{0.35}\left(\mathrm{v}_{\mathrm{s}}\right)^{0.64}\left(\mathrm{P}_{\mathrm{co}}\right)^{1.14},\left(\mathrm{kgmol} / \mathrm{m}^{3} / \mathrm{h}\right)
$$

Mixing and gas dispersion characteristics were defined for the specific impeller/tank geometry used in these experiments.

Using the results presented here. it would be possible to estimate the size and number of commercial stirred tank chlorination reactors, which would be required to produce any specified quantity of magnesium. starting from magnesite. with an accuracy of $\_44 \%$. with $95 \%$ confidence. 


\section{Résumé}

Ce projet de recherche porte sur une étude sur la réaction du solide $\mathrm{MgO}$ (forme du "magnesice". $\mathrm{MgCO}_{3}$ ), avec du $\mathrm{Cl}_{2}$ et du gaz $\mathrm{CO}$. dans du $\mathrm{MgCl}_{2}$ en formé liquide. Cette réaction ce produit dans un contenant agitateur à réaction. Ceci a démontré que le rapport de réaction fut controlé par un transfert de la masse du CO passant de la phase gazeuse à la phase liquide et avait aucun ordre avec la concentration de $\mathrm{MgO}$. il est alors indipendant. A les températures de 743 à $824{ }^{\circ} \mathrm{C}$. le rapport de réaction démontré une activation d’énergie de $80 \mathrm{~kJ} / \mathrm{mol}$, qui est typique d"une réaction controlée par la difusion.

La vitesse de réaction de chlorination est affectic par la temperature et le rapport ds $\mathrm{CO} / \mathrm{Cl}_{2}$. Des estimations des conditions les plus favorables furent obtenues: températurc $\left(\$ 56.6^{\circ} \mathrm{C}\right)$ et le rapport de $\mathrm{CO} / \mathrm{Cl}_{2}(1.24)$. L'addition du gaz $\mathrm{N}_{2}$ a diminué la vitesse de la réaction. Le fer semble avoir un effet très minime sur le temps de réaction aux niveaux testés (jusqu à 560 P.P.M.).

Pour ce qui en est des expériences aux températures de $820^{\circ} \mathrm{C} \pm 5^{\circ} \mathrm{C}$, on obtient une corrélation globale qui démontre une relation entre la réaction du $\mathrm{MgO}$, avec le pouvoir de l'impelleur $\left(\mathrm{kW} / \mathrm{m}^{3}\right)$, la vitesse du gaz $(\mathrm{cm} / \mathrm{s})$ et la pression du $\mathrm{CO}$ (atm.):

Vitesse de réaction $=0.609\left(\mathrm{P}_{\mathrm{f}} / \mathrm{V}_{1}\right)^{0.35}\left(\mathrm{~V}_{\mathrm{s}}\right)^{0.65}\left(\mathrm{~F}_{\mathrm{m}}\right)^{\mathrm{t} .14},\left(\mathrm{kgmol} / \mathrm{m}^{3} / \mathrm{h}\right)$

Les charactéristiques du mélange et de la dispersion des gaz sont definies pour le contenant agitateur à réaction utilisé dans cette expérimentation.

En utilisant les résultats présentès ici, il est possible d'estimer la grandeur et le nombre de contenants agitateur à réaction commercial qui seraient requis pour produire une quantité de magnesium, en dẻbutant avec du "magnesite". en utilisant une marge de confiance de $95 \%$ avec une intervalle de $\pm 44 \%$. 


\section{Acknowledgements}

I wish to thank the financial. moral and technical support of Noranda Inc.. and particularly the employees of the Noranda Technology Center. including: Dr. J.G. Peacey. Dr. D. Poggi. Dr. E. Chin. G. Bishop. E. Delrincon. L. Lavoic. D. Sabadin. and T. Walker.

I would like to thank the Baymag Co. of Calgary. Alberta. for providing the magnesite required for my experiments free of charge.

I would like to thank my thesis supervisor. Prof. R. Harris. for his guidance and support.

I would like to thank Dr. R.A. Berryman. J.G. Lenz and Falconbridge Ltd. for allowing me time from work to complete this thesis.

I would also like to thank my wife, Carol Colman, for her support during the long period of my study, particularly during the writing of this thesis. 


\section{Table of Contents}

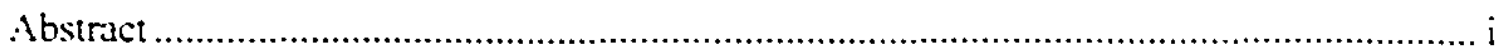

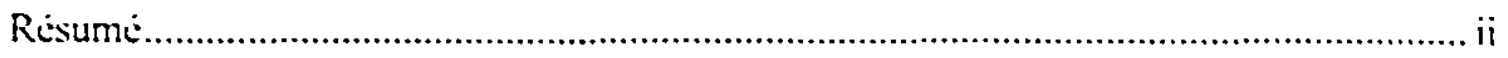

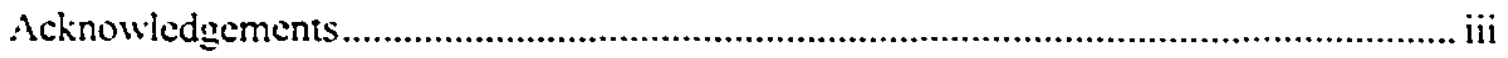

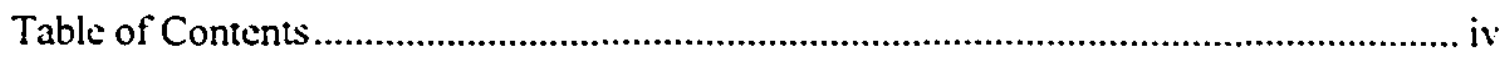

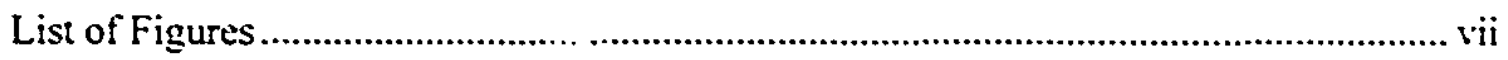

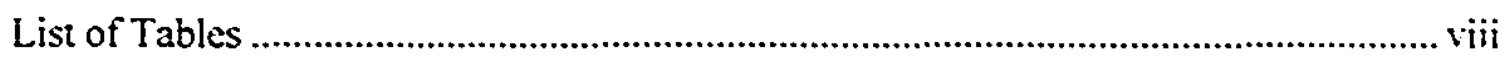

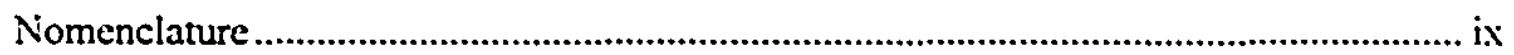

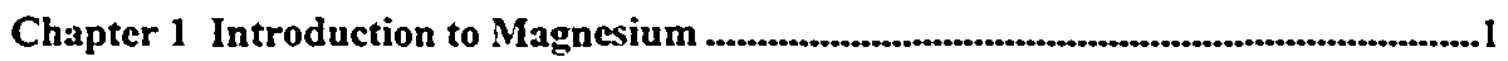

Chapter 2 Magnesium Production Technology ......................................................4

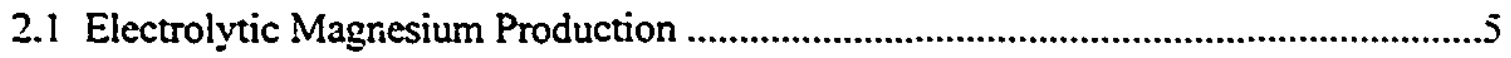

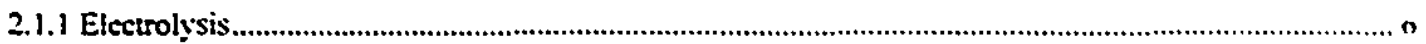

2.1.2 Feed Preparation.......................................................................................................................... 10

2.1.2.1 Magcom - feed pieparation..................................................................................................... 11

2.1 .2 .2 Mascan - feed prenaration ......................................................................................... 17

2.1.2.3 Thermodvamic Considerations of Magnesium Chloride Dehvdration............................................... 20

Chapter 3 Chlorination and Stirred Tank Reactors

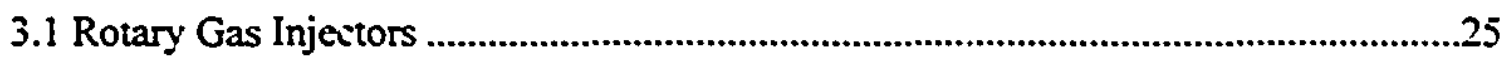

3.2 Gas Liquid Mass Transfer in Stirred Tanks .........................................................27

3.2.1 Mixing Power in Stired Tanks......................................................................................................... 30

Chapter 4 Experimental Part I: Mixing and Gas Injection

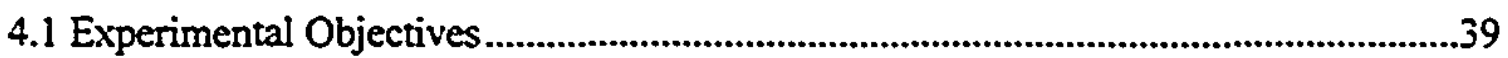

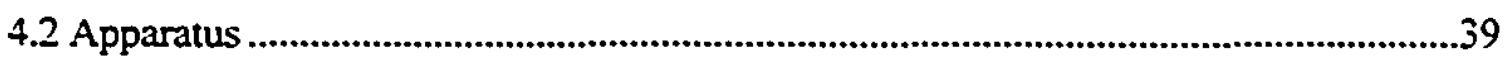

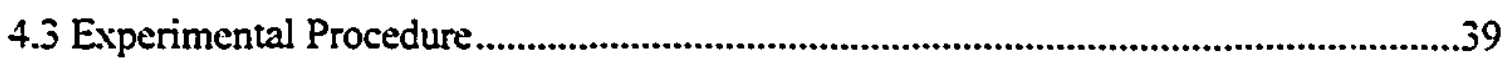

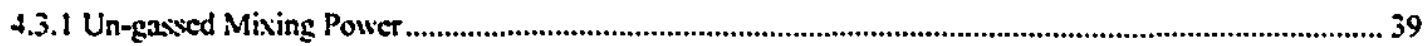

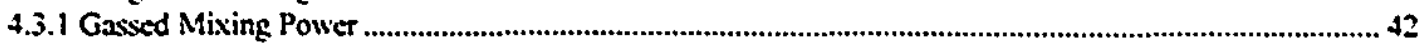

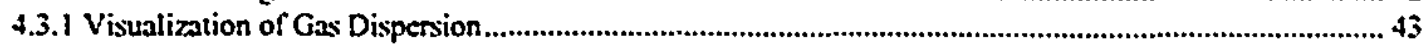


Chapter 5 Experimental Part 11: Reaction Kinetics ................................................4

5.1 Experimental Ohjectives.....................................................................t

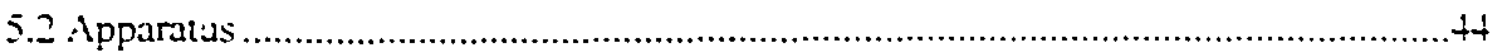

$\$ .2 .1$ I

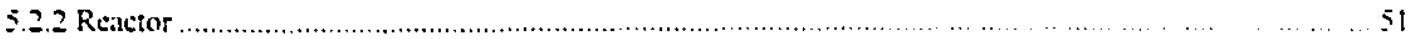

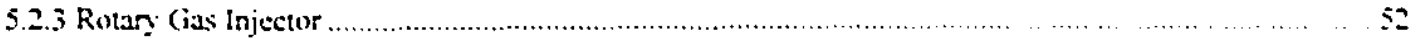

5.2 .4 Controls

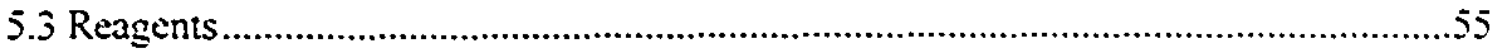

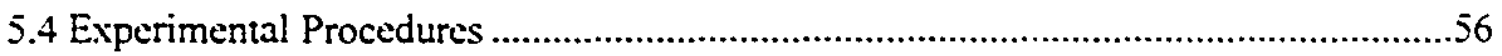

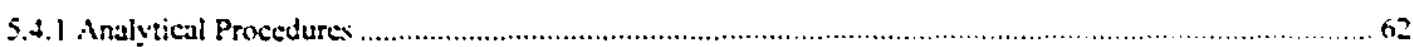

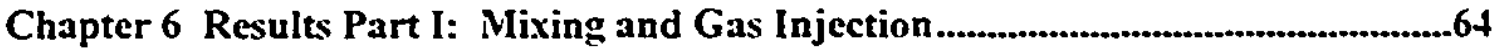

6.1 Un-gassed Mixing Power...............................................................................64

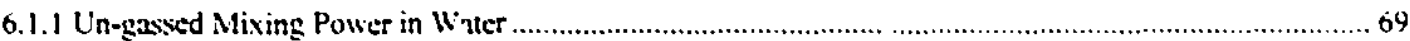

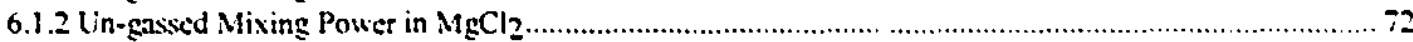

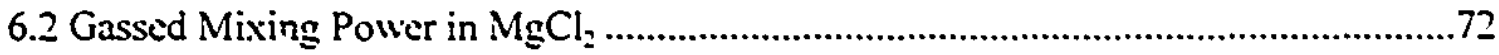

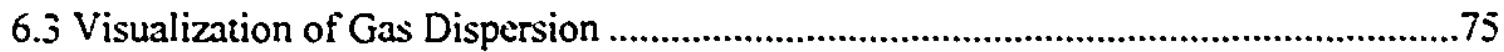

Chapter 7 Results Part II: Chlorination Experiments ............................................81

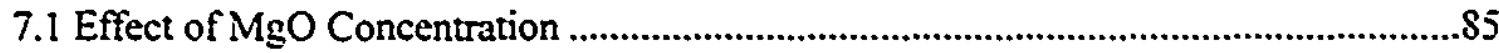

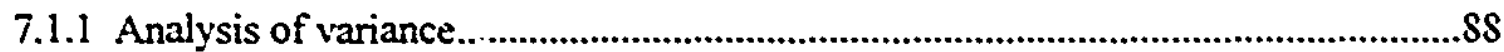

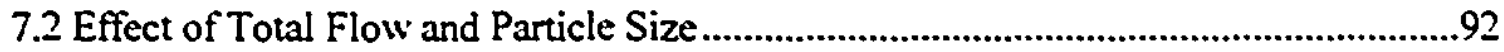

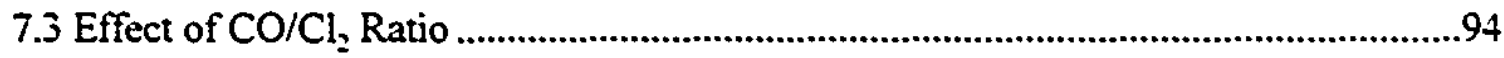

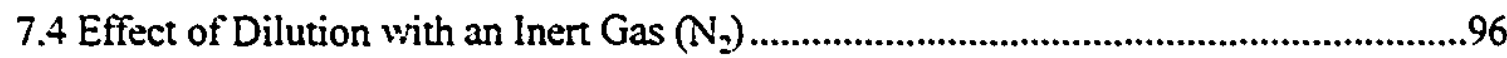

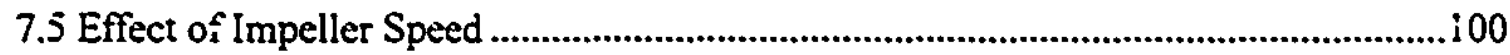

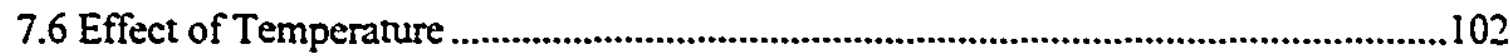

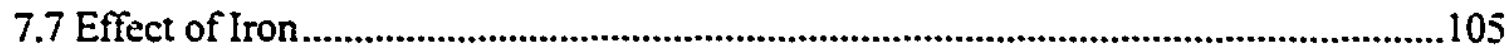

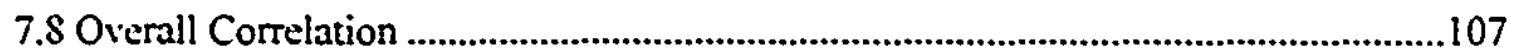

Chapter 8 Discussion 


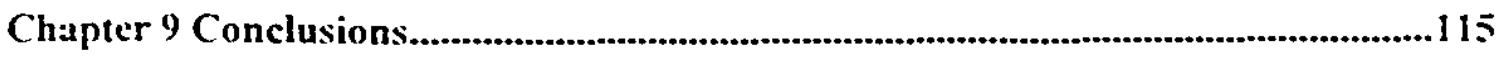

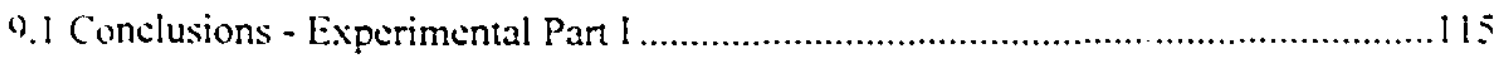

9.2 Conclusions - Experimental Part II .......................................................... 15

Chapter 10 Recommendations for Future Work .................................................... 118

Appendix A - List of Suppliers .............................................................................119

Appendix B - Analysis of the Variance of Experimental Data.................................120

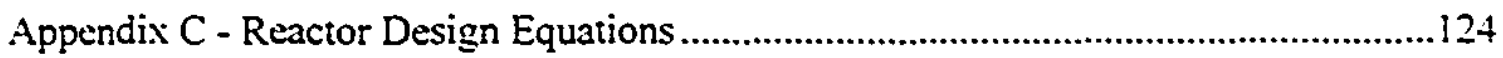

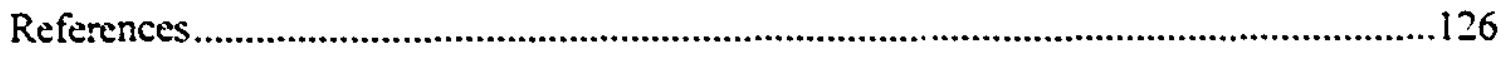




\section{List of Figures}

Figure 1: Westem World Magnesium Consumption by Market $(\text { ( } 094)^{\circ}$........................................

Figure 2: Chloride Ellingham Diagram " ..................................................................................

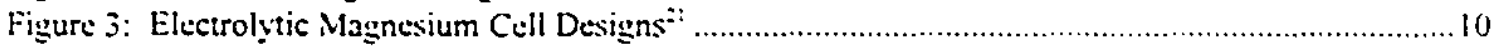

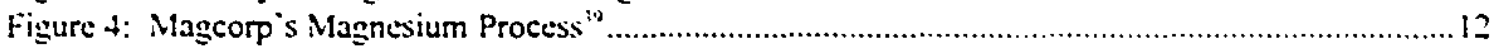

Figure 5: MgO Reaction Rate and Chlorine Utilization Against Ratio of $\mathrm{P}_{\mathrm{Co}} \mathrm{P}_{\mathrm{C}}$ : "........................... 19

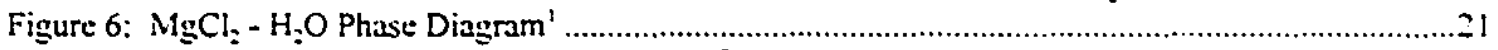

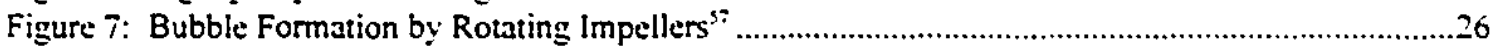

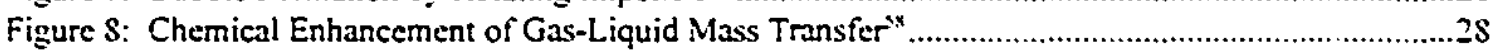

Figure 9: Impeiler Power Number Against Reynolds Number" ...........................................................31

Figure 10: Ratio of Gassed to Un-gassed Power Against Aeration Number" ".......................................3

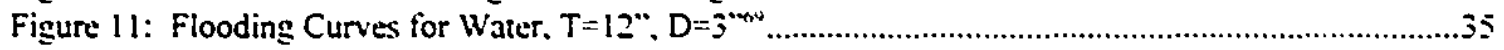

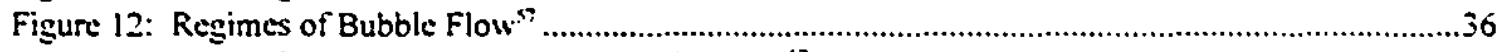

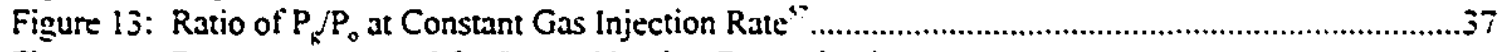

Figure 14: Dynamometer used for Power Number Determination ...................................................... \&

Figure 15: Experimental Apparatus - General Schematic .................................................................. 15

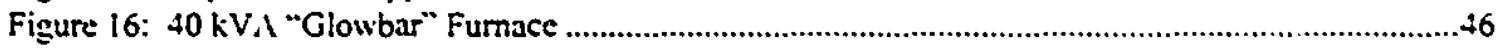

Figure 17: New and Used Reacior Crucibles, with New Gas Injector ....................................................

Figure 18: Graphite Reactor and Impeller - General Schematic .......................................................... 4 S

Figure 19: Schematic of Graphite Impeller and Shaft ......................................................................9.

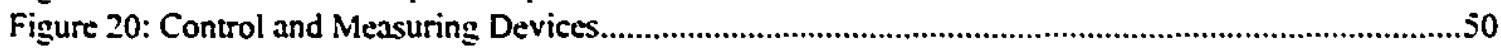

Figure 21: Magnesite Ore as Received and 106-150 um Crushed Fraction.............................................57

Figure 22: Melt Sampling Procedure ..........................................................................................60

Figure 23: Power Number Against Impeller R.P.M. ........................................................................65

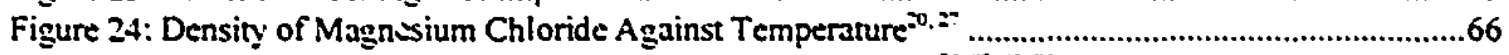

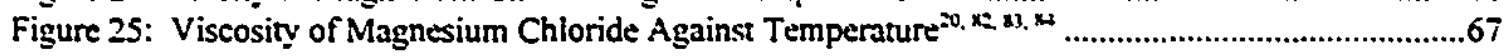

Figure 26: Power Number Against Impeller Reynolds Number ..........................................................68

Figure 27: Electrical Power Against Speed For New Graphite Impeller in Water.....................................71

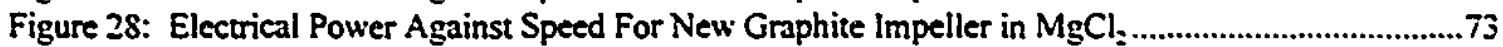

Figure 29: $\mathrm{F}$ atio of Gassed to Un-gassed Power for $\mathrm{New}$ Graphite Impeller in $\mathrm{MgCl}$...............................74

Figure 30: jas Dispersion at 200 R.P.M. and 16 Actual L/min .........................................................7.

Figure 31: Gas Dispersion at 600 R.P.M. and 16 Actual L/min .........................................................78

Figure 32: Gas Dispersion at 800 R.P.M. and 16 Actual L/min .............................................................79

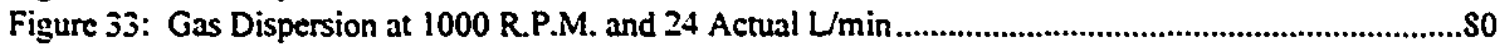

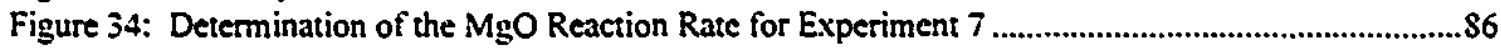

Figure 35: Temperature and CO Flow Rate Against Time for Experiment 7 .............................................87

Figure 36: The Effects of Total Gas Flow and MgO Particle Size on the Reaction Rate of MgO ...............93

Figure 37: The Effect of $\mathrm{CO} / \mathrm{Cl}_{2}$ Ratio on the Reaction Rate of $\mathrm{MgO}$...................................................95

Figure 38: The Effect of Dilution with $\mathrm{N}_{2}$ on the MgO Reaction Rate at Constant Tutal Gas Flow............98

Figure 39: The Effect of Increasing Total Gas Volume Using an inert Gas on the MgO Reaction Rate.....99

Figure 40: The Effect of Impeller Speed on the MgO Reaction Rate .......................................................101

Figure 41: The Effect of Increasing Temperature on the MgO Reaction Rate........................................104

Figure 42: The Effect of Iron on the MgO Reaction Rate................................................................... 106

Figure 43: The Effect of Impeller Speed. Gas Injection. $P_{c o}$ and Initial MgO on the Reaction Rate ........ 109

Figure 4: Conceptual Design of An Industrial Chlorinator ...............................................................113

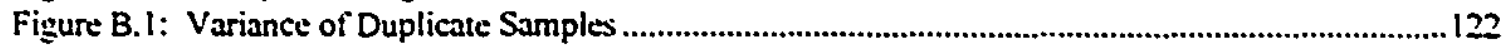

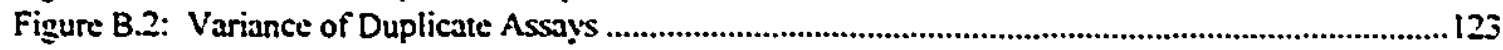




\section{List of Tables}

Table 1: World Production of Various Metals (1993) (1000 mt) …................................

Table 2: Estimated Magnesium Capacity (1995) ${ }^{r}$....................................................

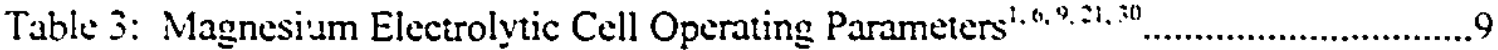

Table 4: Typical Composition of Spray Dried Magnesium Chloride"................................13

Table 5: Thermodynamics of Magnesium Chloride Dehydration".................................20

Table 6: Calculated Activities of $\mathrm{MgCl}_{2}$ in Mixtures of $\mathrm{MgCl}_{2}$ and $\mathrm{KCl}^{20} \ldots \ldots \ldots \ldots \ldots \ldots . . . .22$

Table 7: Dimensions and Dimensionless Ratios for Experimental Apparatus..................53

Table S: Baymag Magnesite $\left(\mathrm{MgCO}_{3}\right)$ - Head Samples ..................................................58

Table 9: Aldrich Anhydrous Magnesium Chloride Assays .................................................5

Table 10: Dynamometer Experimental Data .....................................................................69

Table 11: Summary of Experimental Conditions ............................................................82

Table 12: Summary of Experimental Results ...................................................................83

Table B.I Variance of Experimental Data Due to Sampling and Analysis .....................121 


\section{Nomenclature}

\begin{tabular}{|c|c|c|c|}
\hline Symbo & Description & $\begin{array}{l}\text { Typical } \\
\text { Inits }\end{array}$ & E.l. \\
\hline$\mu$ & thuid viscosity & $c p$ & Pas \\
\hline$\varepsilon$ & $\begin{array}{l}\text { fraction of sas-liquid dispersion occupied hy gas } \\
\text { (hold-up) }\end{array}$ & & unitless \\
\hline$\sigma$ & surface tension & & $\mathrm{N} / \mathrm{m}$ \\
\hline$\Delta \rho$ & difference in density & & $\mathrm{kg} / \mathrm{m}^{\prime}$ \\
\hline$\rho$ & density & $\cong \mathrm{cm}^{\prime}$ & $\mathrm{kg} / \mathrm{m}^{3}$ \\
\hline • & kinematio viscosity & & $\mathrm{m}: \mathrm{s}$ \\
\hline$\because$ & activity coefficient of species $i$ & & unitless \\
\hline $\mathbf{a}$ & gas-liquid intertacial area per unit liquid volume & $\mathrm{m}: \mathrm{m}^{:}$ & $m^{-1}$ \\
\hline$a_{3}$ & activity if species $i$ & & unitless \\
\hline b & baffle width & $\mathrm{mm}$ & m \\
\hline $\mathrm{C}$ & impeller height above bottom & $\mathrm{mm}$ & $\mathrm{m}$ \\
\hline$c^{*}$, & equilibrium concentration of species i & & $\mathrm{kgmol} / \mathrm{m}^{3}$ \\
\hline$c_{1}$ & bulk concentration of species i & & $\mathrm{kgmol} / \mathrm{m}^{3}$ \\
\hline c & molar density & & $\mathrm{kgmol} / \mathrm{m}^{3}$ \\
\hline D & impeller diameter & $\mathrm{mm}$ & $\mathrm{m}$ \\
\hline $\mathcal{D}_{\mathrm{L}}$ & diffusivity & & $\mathrm{m} \% / \mathrm{s}$ \\
\hline$d_{b}$ & mean bubble diameter & $\mathrm{mm}$ & $\mathrm{m}$ \\
\hline d & mean particle diameter & $\mu \mathrm{m}$ & $\mathrm{m}$ \\
\hline d & width/diameter of impeller slots & $\mathrm{mm}$ & m \\
\hline E & gas-liquid equilibrium constant & & unitless \\
\hline E & reduction potential under given conditions & & $\mathrm{v}$ \\
\hline $\mathrm{E}^{\mathrm{o}}$ & standard reduction potential & & $\mathrm{V}$ \\
\hline $\mathrm{F}$ & Faraday"s constant ( 96489 coulombs/equiv.) & C/equir. & \\
\hline$\Delta \mathrm{G}$ & free energy of reaction under given conditions & $\mathrm{kJ} / \mathrm{gmol}$ & $\mathrm{J} / \mathrm{kgmol}$ \\
\hline$\Delta G^{\circ}$ & standard free energy of reaction & $\mathrm{kJ} / \mathrm{gmol}$ & $\mathrm{J} / \mathrm{kgmol}$ \\
\hline $\mathrm{g}$ & acceleration due to gravity $\left(9.81 \mathrm{~m} / \mathrm{s}^{2}\right)$ & & $\mathrm{m} / \mathrm{s}^{2}$ \\
\hline $\mathrm{h}$ & liquid height above impeller & $\mathrm{mm}$ & m \\
\hline $\mathrm{H}$ & total liquid height & $\mathrm{mm}$ & $\mathrm{m}$ \\
\hline$h_{i}$ & Henrian coefficient for species $i$ & $\mathrm{~mol} / \mathrm{L} / \mathrm{aum}$ & $\mathrm{kgmol} / \mathrm{m}^{3} / \mathrm{Pa}$ \\
\hline 1 & current & & A \\
\hline k & generic proportionality constant & & unitless \\
\hline $\mathrm{k}_{\mathrm{r}}$ & gas film transfer coefficien! & & $\mathrm{m} / \mathrm{s}$ \\
\hline$k_{\mathrm{L}}$ & liquid film transfer coefficient & & $\mathrm{m} / \mathrm{s}$ \\
\hline$K_{L}$ & overall gas to liquid mass transfer coefficient & & $\mathrm{m} / \mathrm{s}$ \\
\hline $\mathrm{L}$ & length of lever arm & & $\mathbf{m}$ \\
\hline $\mathbf{m}$ & mass of weights used on dynamometer & I & $\mathrm{kg}$ \\
\hline
\end{tabular}




\begin{tabular}{|c|c|c|c|}
\hline M & impeller torque & & $\mathrm{Nm}$ \\
\hline $\mathrm{n}$ & number of equivalents per mole & equiv./mol & \\
\hline $\begin{array}{l}n \\
N\end{array}$ & $\begin{array}{l}\text { number of baffles } \\
\text { impeller speed }\end{array}$ & $\min .^{-1}$ & $\begin{array}{l}\text { unitless } \\
s^{-1}\end{array}$ \\
\hline $\mathrm{N}_{2}$ & aeration number - (Q/ND) & & unitless \\
\hline$N_{\text {rr }}$ & Froude number $-\left(N^{2} D / g\right)$ & & unitless \\
\hline$N_{p}$ & power number - $\left(\mathrm{P}_{0} / \rho N^{3} \mathrm{D}^{5}\right)$ & & unitless \\
\hline$N_{R a}$ & Rayleigh number $-\left(d_{b}{ }^{3} \Delta \rho g / D_{L} \mu\right)$ & & unitless \\
\hline $\mathrm{N}_{\mathrm{Re}}$ & Reynolds number - $\left(\rho \mathrm{ND}^{2} / \mu\right)$ & & unitless \\
\hline $\mathrm{N}_{\mathrm{Sh}_{2}}$ & Sherwood number $-\left(K_{L} d_{b} / c D_{L}\right)$ & & unitless \\
\hline $\mathrm{N}_{\mathrm{we}}$ & Weber number - $\left(\rho N^{2} D^{3} / \sigma\right)$ & & unitless \\
\hline $\mathrm{P}$ & impeller power & & W \\
\hline$P_{2}$ & power in air (transmission losses) & & W \\
\hline$P_{E}$ & gassed power & & W \\
\hline$P_{i}$ & partial pressure of species $\mathrm{i}$ & atm. & $\mathrm{Pa}$ \\
\hline$P_{0}$ & un-gassed power & & : W \\
\hline$P_{1}$ & total motor power including losses & & W \\
\hline Q & total gas flow rate at reactor temperature & $\mathrm{mL} / \mathrm{min}$. & $\mathrm{m}^{3} / \mathrm{s}$ \\
\hline$Q_{t}$ & total gas flow rate at S.T.P. & $\mathrm{mL} / \mathrm{min}$ & $\mathrm{m}^{3} / \mathrm{s}$ \\
\hline $\mathbf{R}$ & ideal gas law constant $(\$ .314 \mathrm{~J} /(\mathrm{mol} \mathrm{K}))$ & $\mathrm{J} /(\mathrm{mol} \mathrm{K})$ & $\mathrm{J} /(\mathrm{kgmol} \mathrm{K})$ \\
\hline $\mathrm{R}$ & reaction rate & $\mathrm{mol} / \mathrm{L} / \mathrm{h}$ & $\mathrm{kgmol} / \mathrm{m}^{3} / \mathrm{s}$ \\
\hline$R_{0}$ & chlorination rate & $\mathrm{mol} / \mathrm{L} / \mathrm{h}$ & $\mathrm{kgmol} / \mathrm{m}^{3} / \mathrm{s}$ \\
\hline$R_{d}$ & chlorination rate diluted with inert gas & $\mathrm{mol} / \mathrm{L} / \mathrm{h}$ & $\mathrm{kgmol} / \mathrm{m}^{3} / \mathrm{s}$ \\
\hline $\mathbf{S}$ & $\begin{array}{c}\text { geometric correction factor for } \\
\text { Zwietering's equation }\end{array}$ & & unitless \\
\hline S & impeller shaft diameter & $\mathrm{mm}$ & $\mathrm{m}$ \\
\hline$S_{b}$ & impeller shaft bore diameter & $\mathrm{mm}$ & m \\
\hline $\mathrm{T}$ & temperature & & ${ }^{\circ} \mathrm{C}$ or $\mathrm{K}$ \\
\hline $\mathrm{T}$ & tank diameter & $\mathrm{mm}$ & m \\
\hline V & voltage & & V \\
\hline $\mathrm{V}_{1}$ & volume of liquid & L & $\mathrm{m}^{3}$ \\
\hline$V_{1}$ & total volume of gas-liquid dispersion & $\mathrm{L}$ & $\mathrm{m}^{3}$ \\
\hline$v_{3}$ & superficial gas velocity at reactor temperature & $\mathrm{cm} / \mathrm{s}$ & $\mathrm{m} / \mathrm{s}$ \\
\hline W & impeller thickness & $\mathbf{m m}$ & $\mathrm{m}$ \\
\hline $\mathrm{W}_{8}$ & height of gas holes above bottom of impeller & $\mathrm{mm}$ & $\mathrm{m}$ \\
\hline $\mathrm{X}$ & $\%$ weight of solids in slurry & & $\%$ \\
\hline$X_{i}$ & mole fraction of species $i$ & & unitless \\
\hline
\end{tabular}




\section{Chapter 1 Introduction to Magnesium}

Magnesium occurs naturally, in the form of a large number of compounds such as: dolomite $\left(\mathrm{MgCO}_{3}{ }^{*} \mathrm{CaCO}_{3}\right)$, magnesite $\left(\mathrm{MgCO}_{3}\right)$, carnallite $\left(\mathrm{MgCl}_{2} * \mathrm{KCl}^{*} 6 \mathrm{H}_{2} \mathrm{O}\right)$. serpentine $\left(\mathrm{Mg}_{6}(\mathrm{OH})_{6} \mathrm{Si}_{4} \mathrm{O}_{11}{ }^{*} \mathrm{H}_{2} \mathrm{O}\right)$ and magnesium chloride $\left(\mathrm{MgCl}_{2}\right)$, which occurs in sea water, surface and underground brines'. Magnesium is the eighth most abundant element in the earth's crust, at an average concentration of $2 \%^{2}$.

Magnesium has high strength and stiffness to weight ratio"s. making it suitable for use as a structural metal ${ }^{3.4}$. Being 4.5 times lighter than iron and 1.6 times lighter than aluminum', magnesium is the lightest (s.g. 1.738), as well as the third most common structural metal after iron and aluminum 6 . The production of magnesium is compared to such metals as iron and aluminum in Table $1 \%$. Some of magnesium's applications include: pressure die castings, alloying agent for metals such as aluminum, reduction of titanium, a metal deoxidant and desulfurizer, and Grignard reagent ${ }^{3}$. A breakdown of magnesium consumption by market is given in Figure 1 , for the year $1994^{8}$.

Table 1: World Production of Various Metals (1993) (1000 mt)

\begin{tabular}{cccc}
\hline Metal & Canadian & American & World \\
\hline Fe (steel) & 10,000 & 87,000 & 728,000 \\
$\mathrm{Al}$ & 2,200 & 3,700 & 19,000 \\
$\mathrm{Cu}$ & 750 & 1,770 & 9,300 \\
$\mathrm{Zn}$ & 1,312 & 552 & 7,000 \\
$\mathrm{~Pb}$ & 300 & 400 & 3,200 \\
$\mathrm{Ni}$ & 172 & 2 & 826 \\
$\mathrm{Mg}$ & 28 & 145 & 303 \\
$\mathrm{Sn}$ & - & - & 175 \\
\hline
\end{tabular}




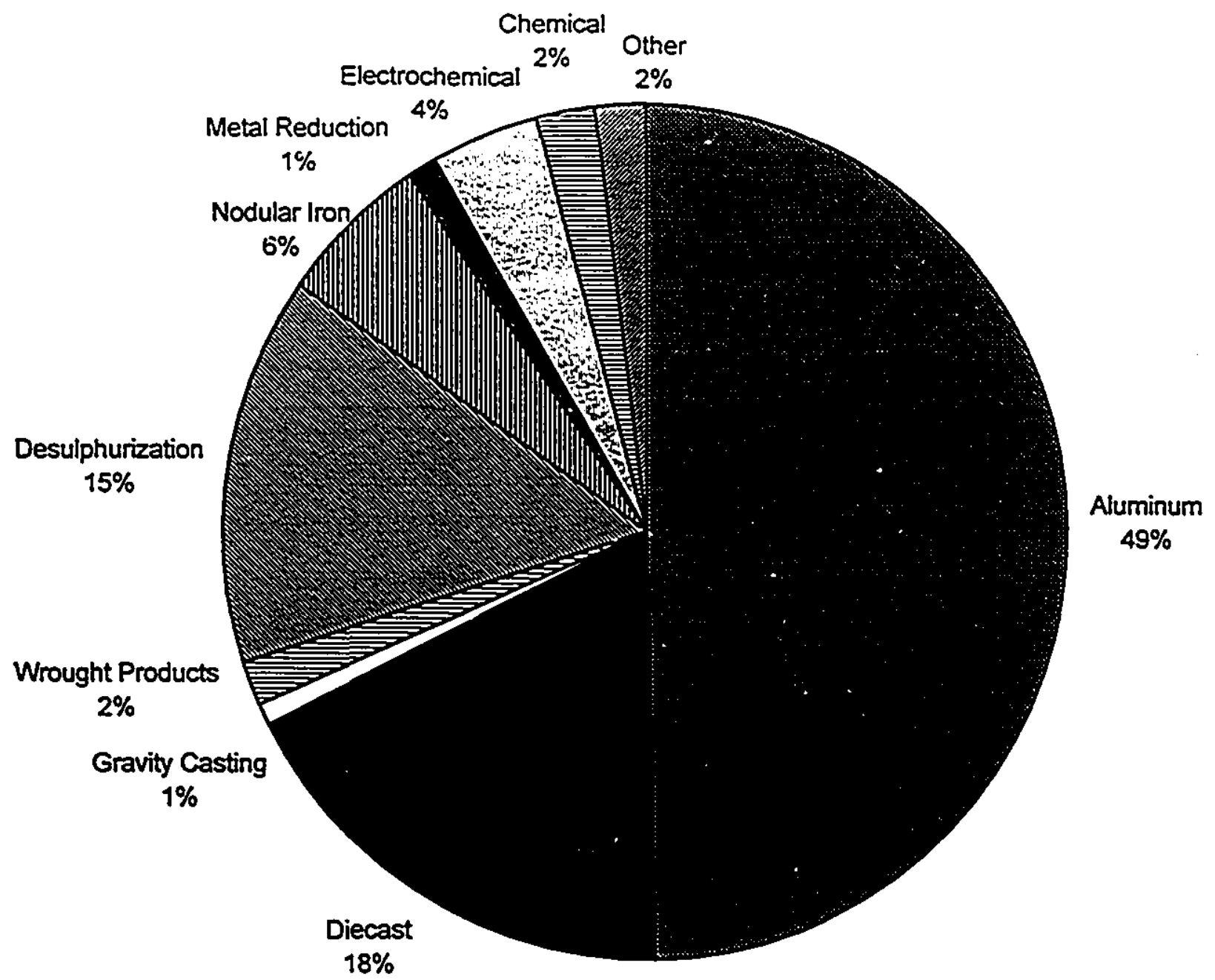

Figure 1: Western World Magnesium Consumption by Market (1994) 
What is surprising about Table $\mathrm{l}$ is how little magnesium $(303.000 \mathrm{mt})$ is manufactured (less than $2 \%$ as much as aluminum). For magnesium use to grow significantly, it must begin to compete directly with aluminum in the automotive and structural markets. The magnesium industry has traditionally been dominated by a small number of suppliers. These suppliers have control over the amount of magnesium produced and have little incentive to compete in new and volatile markets.

A review of magnesium economics completed in 1981. indicated that pricing practices by the suppliers and not production cost. is the reason that magnesium does presently compete with aluminum in the structural market'. New suppliers must enter the market. In order to have a competitive advantage over existing suppliers, research must be made into innovative technologies for producing magnesium and its antecedents. This research work is the result of such a study. 


\section{Chapter 2 Magnesium Production Technology}

About three quarters of the world's $303.000 \mathrm{mt}$ of magnesium is produced by the clectrolysis of magnesium chloride $\left(\mathrm{MgCl}_{2}\right)^{\mathrm{N}}$. The remaining quarter is produced by metallothermic reduction with FeSi of either magnesite or dolomite, using the Pidgeon ${ }^{10}$. 11. 12 or the Magnetherm processes ${ }^{13}$ 14. 15. 16. 17. Other commercial magnesium processes which have been used in the past include: carbothermic reduction at atmospheric pressure $^{18}$ and electrolytic reduction of magnesium oxide from a molten fluoride bath ${ }^{19}$.

The estimated production capacities of magnesium for 1995 by various companies. countries, and methods are listed in Table $2^{7.8}$.

Table 2: Estimated Magnesium Capacity (1995)

\begin{tabular}{ccccc}
\hline Producer & Country & Capacity (mt) & Process & Raw Material \\
\hline $\begin{array}{c}\text { Dow } \\
\text { Magnesium }\end{array}$ & U.S.A. & 60,000 & Electrolytic & $\begin{array}{c}\text { Sea water, } \\
\text { seashells, dolomite }\end{array}$ \\
Magcorp & U.S.A. & 35,000 & Electrolytic & Great salt lake brine \\
$\begin{array}{c}\text { Northwest } \\
\text { Alloys }\end{array}$ & U.S.A. & 49,000 & Magnetherm & Dolomite \\
Timminco & Canada & 7,000 & Pidgeon & Dolomite \\
Norsk-Hydro & Canada & 45,000 & Electrolytic & Magnesite \\
Brasmag & Brazil & 10,000 & $\begin{array}{c}\text { Silicothermic } \\
\text { (Pidgeon Variant) }\end{array}$ & Dolomite \\
Norsk-Hydro & Norway & 35,000 & Electrolytic & Brine (new process) \\
Pechiney & France & 15,000 & Magnetherm & Dolomite \\
China & & 18,000 & Pidgeon & Dolomite or \\
magnesite & Carnallite \\
Former Soviet & & 62,000 & Electrolytic & \\
Union & & (not for Ti Prod.) & & \\
Total: & & 336,000 & & \\
\hline
\end{tabular}


Only the topic of electrolytic magnesium production from $\mathrm{MgCl}_{2}$ will be dealt with in detail, since this forms the basis for most magnesium production and is directly related to this study. For those interested, magnesium production technologies are covered in great detail in several publications. The most comprehensive treatise on magnesium. is the monograph by Kh.L. Strelets published in $1977^{20}$. An older (1966), but still useful text is available from E.F. Emlet ${ }^{19}$. Two excellent review papers are also available from $G$. Mamantov, C.B. Mamantov and J. Braunstein $(1987)^{1}$ and N. Jarrett (1981) ${ }^{\circ}$.

\subsection{Electrolytic Magnesium Production}

Magnesium was first produced by Sir Humphry Davy in $1808^{21}$. He produced magnesium by distilling an amalgam he had produced electrolytically. from a paste consisting of magnesia and cinnabar in naptha ${ }^{19,22}$. Magnesium was directly produced electrolytically for the first time, by Michael Faraday who electrolyzed fused magnesium chloride, in $1833^{\prime}$. This use of fused magnesium chloride for electrolysis, continues to be the basis of all modern magnesium processes.

Modern electrolytic processes can be divided up into several distinct production operations:

1) feed preparation,

2) electrolysis, and

3) refining and casting.

Electrolysis will be dealt with first, since it determines the requirements for feed preparation. Refining and casting will not be discussed, as they do not relate to this study. 


\subsubsection{Electrolýsis}

Magnesium metal can not be electrolyzed from an aqueous solution. due to its high standard reduction potential $(-2.375 \text { vs. S.H.E })^{23}$. Therefore, all modern electrolytic magnesium processes operate with a fused salt electrolyte. The chloride salt of magnesium is used as the basis for cell electrolytes. for several practical reasons: abundance in nature, cheaply produced low melting point eutectics. low metallic magnesium solubility, and low reactivity with electrodes ${ }^{19}$.

If magnesium chloride is electrolyzed under standard conditions at its melting point $\left(714^{\circ} \mathrm{C}^{24}\right)$ :

$$
\begin{array}{ll}
\mathrm{MgCl}_{2} & =\mathrm{Mg}_{(\mathrm{l})}+\mathrm{Cl}_{2(\mathrm{k})} \\
\Delta \mathrm{G}^{0}(\mathrm{l}) & =484144 \mathrm{~J} / \mathrm{mol} \text { or } 5.5 \mathrm{kWh} / \mathrm{kg} \text { at } 714^{\circ} \mathrm{C}^{2 \mathrm{~s}}
\end{array}
$$

The theoretical reduction potential for Reaction (1) can be calculated from equation [1]:

$$
\begin{array}{lll}
\Delta G^{0} & = & -n F E^{\circ} \\
E^{\circ}(1) & = & -2.50 \mathrm{~V}
\end{array}
$$

Pure magnesium chloride is not normally used as a cell electrolyte. Better properties in terms of: conductivity, density, surface tension, magnesium solubility and fluidity are obtained by using mixtures of different chlorides. The chlorides, which can be used to form the electrolyte can be found by referring to an Ellingham diagram of the chlorides, such as Figure $2^{26}$. The chlorides that are more stable than $\mathrm{MgCl}_{2}$ such as $\mathrm{CaCl}_{2}, \mathrm{NaCl}$, $\mathrm{KCl}, \mathrm{BaCl}_{2}$ and $\mathrm{LiCl}$ can be used. It should be noted that the chlorides, that are less stable than $\mathrm{MgCl}_{2}$ (e.g. $\mathrm{FeCl}_{2}, \mathrm{ZrCl}_{4}, \mathrm{AlCl}_{3}$ ) are obviously detrimental impurities and must be removed during feed preparation, since they will be preferentially reduced during electrolysis, contaminating the product magnesium. 

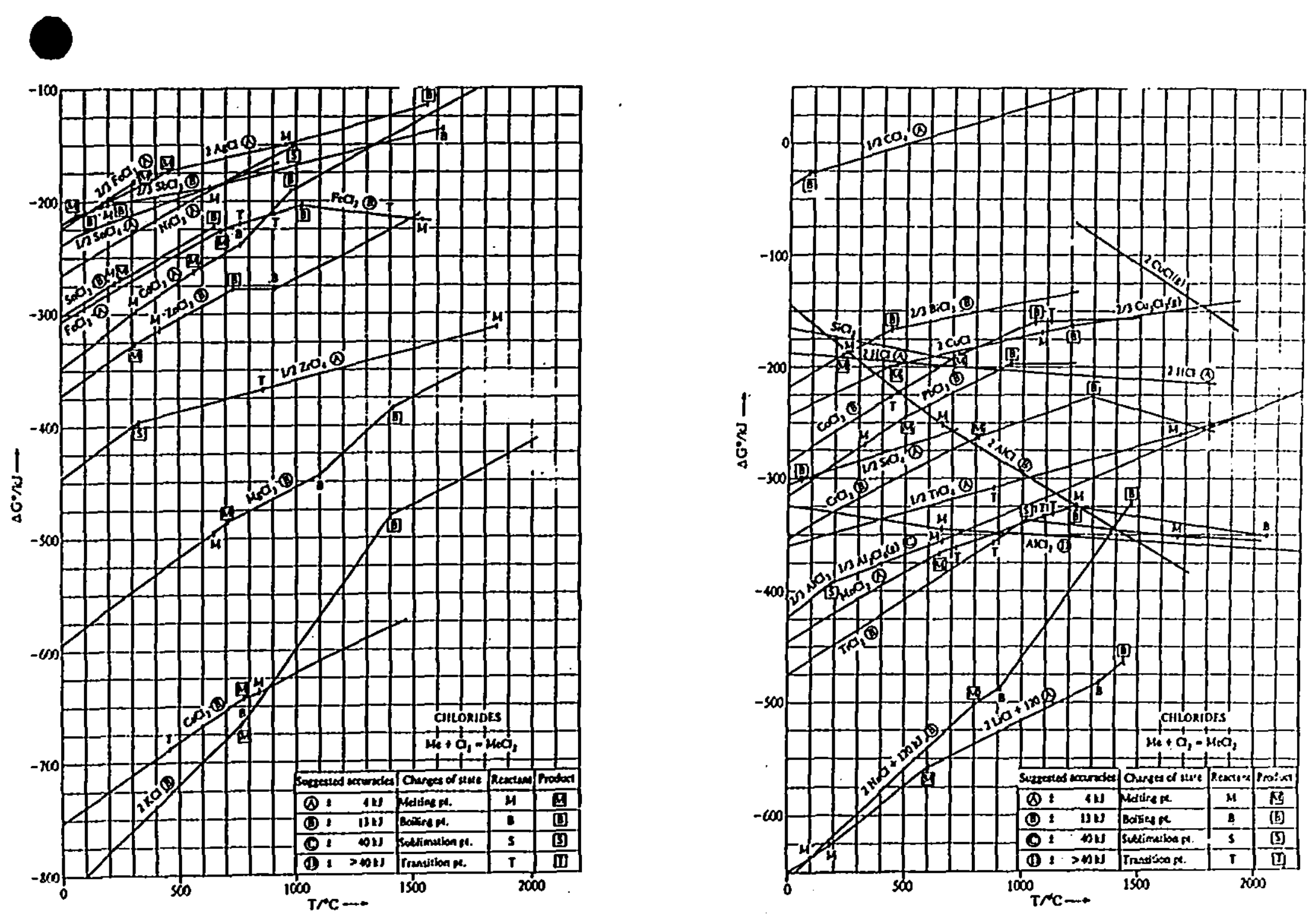

Figure 2: Chloride Ellingham Diagram ${ }^{26}$ 
Liquid magnesium produced by electrolysis. can be made to either float or sink in the cell. depending on the choice of electrolyte components. Normally the magnesium is made to float in order to prevent contamination with sludge. Typical cell electrolyte compositions are: $\mathrm{MgCl}_{2}(10-15 \%), \mathrm{CaCl}_{3}(40 \%), \mathrm{NaCl}(30-40 \%)$, and $\mathrm{KCl}(5-20 \%)^{\circ}$. Commercial cells operate at about $2.7-2.8 \mathrm{~V}$, at these compositions and about $700^{\circ} \mathrm{C}^{20}$. G.J. Janz et. al. have published good references for the physio-chemical and electrical properties of molten salts ${ }^{24.27}$. Phase diagrams and properties of mixed chloride systems. useful in electrolysis, have been summarized by Strelets ${ }^{20}$.

Each magnesium producer operates its own variety of electrolysis cell. due to the proprietary nature of the industry. Several producers use variants of the I.G. Farben cell ${ }^{\text {s. }}$. 29. which uses intemal diaphragms to separate the magnesium and chlorine (in order to prevent the reverse of Reaction (1) and corresponding loss of current efficiency). The use of diaphragms increases anode to cathode spacing and the resistive voltage drop. therefore diaphragmless cells have been developed, including designs by Norsk-Hydro" and VAMI ${ }^{30}$.

Dow Magnesium ${ }^{31}$, which operates the largest single magnesium plant in the world. uses its own cell technology. The Dow cell is specifically designed to operate using semidehydrated magnesium chloride. which causes a number of operating difficulties including: higher sludge formation and higher graphite and energy consumption than I.G. cells 6 .

Recently, a multi-polar cell design has been commercialized by Alcan at the Osaka Titanium Company, in Japan ${ }^{32 .}{ }^{33}$. This cell places several electrically unconnected graphite plates between each cathode and anode. Each intervening graphite plate becomes a bi-polar electrode by applying sufficient voltage. This design has the advantage that the normal losses associated with distributing current to each electrode are essentially eliminated. In addition. with no diaphragms, close clectrode spacing is 
possible and this increases the cell's volumetric production rate (reducing capital cost) and reduces energy consumption from electrolyte resistance. Good hydrodynamic design is crucial to reducing the time that chlorine bubbles and magnesium droplets have to back react in the spaces between the electrodes:" In diaphragmless cells, current efficiency drops by $2.5 \%$ for every 10 "C rise in temperature between $670-750$ " $\mathrm{C}$.". Good temperature control is almost certainly a requirement of the Alcan design.

The operating parameters of various cells are given in Table $3^{1,4,9,21,: 00}$ and a schematic appears in Figure $3^{21}$.

Table 3: Magnesium Electrolytic Cell Operating Parameters $16,6.921 .30$

\begin{tabular}{|c|c|c|c|c|c|}
\hline & Dow & I.G. & $\begin{array}{l}\text { Norsk- } \\
\text { Hydro } \\
\text { (new } \\
\text { cell) }\end{array}$ & $\begin{array}{l}\text { V.A.M.I. } \\
\text { (mono- } \\
\text { polar) }\end{array}$ & $\begin{array}{l}\text { Alcan } \\
\text { (multi- } \\
\text { polar) }\end{array}$ \\
\hline Temperature $\left({ }^{\circ} \mathrm{C}\right)$ & 700 & 740 & N/A & N/A & N/A \\
\hline Current (kA) & 90 & 150 & 400 & 180 & $80-140$ \\
\hline Current Efficiency (\%) & $75-80$ & $80-85$ & $92-93$ & $\$ 5-90$ & 82 \\
\hline Voltage $(\mathrm{V})$ & 6.0 & $5.5-7.0$ & N/A & $5.0-6.0$ & N/A \\
\hline $\begin{array}{l}\text { Specific Energy } \\
(\mathrm{kWh} / \mathrm{kg})\end{array}$ & 18.5 & $15-18$ & 12 & $13-14$ & $9-10$ \\
\hline $\begin{array}{l}\text { Anode/Cathode } \\
\text { Spacing }(\mathrm{cm})\end{array}$ & 4 & $6-7$ & N/A & N/A & N/A \\
\hline $\begin{array}{c}\text { Anode Graphite } \\
\text { Consumption } \\
(\mathrm{kg} / \mathrm{kg} \text { of } \mathrm{Mg})\end{array}$ & 0.1 & 0.015 & N/A & N/A & 0.00065 \\
\hline $\begin{array}{l}\text { Sludge Formation } \\
(\mathrm{kg} / \mathrm{kg} \text { of } \mathrm{Mg})\end{array}$ & 0.25 & $<0.1$ & N/A & N/A & $\begin{array}{l}0.005- \\
0.008\end{array}$ \\
\hline $\begin{array}{l}\text { Metal Output } \\
\text { (kg/day Mg) }\end{array}$ & 500 & N/A & N/A & N/A & 3000 \\
\hline
\end{tabular}



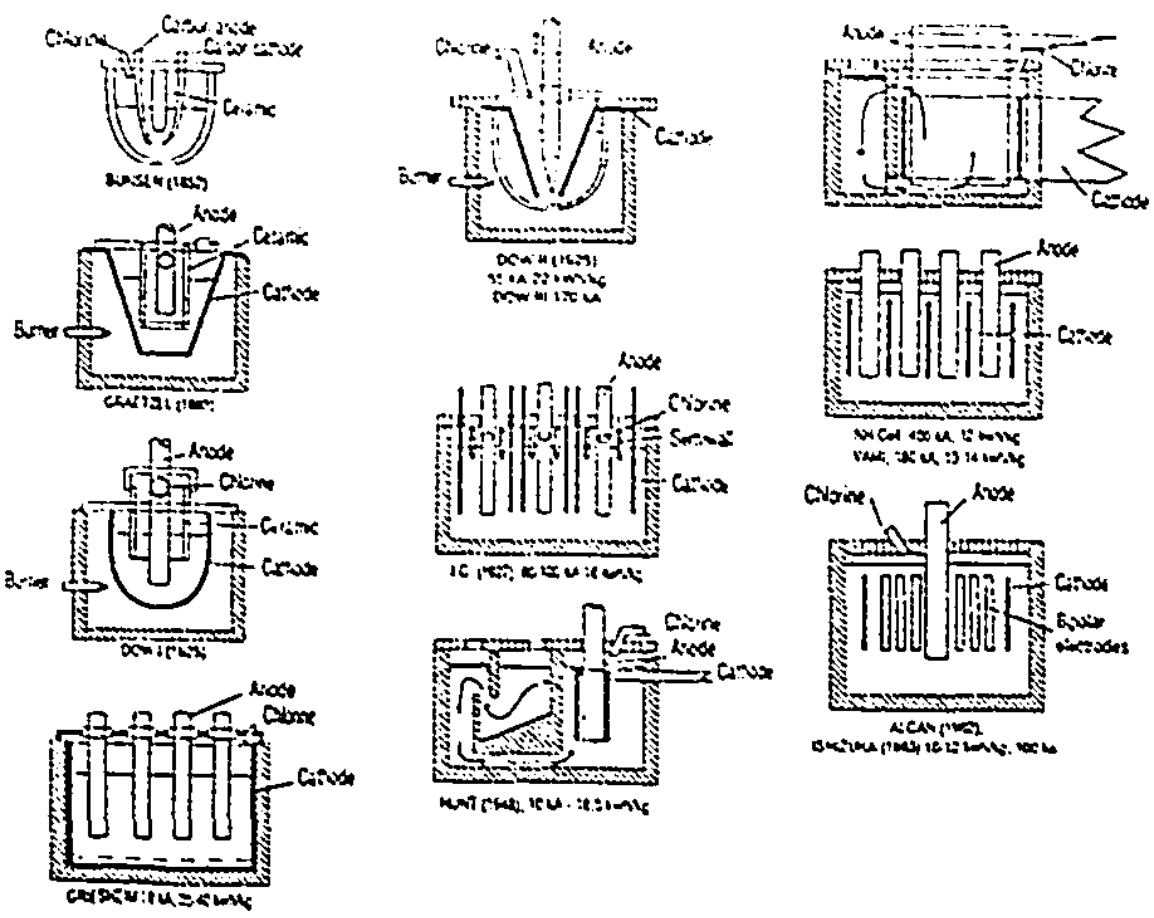

Figure 3: Electrolytic Magnesium Cell Designs ${ }^{21}$

\subsubsection{Feed Preparation}

The initial source of magnesium for electrolytic processes can be either aqueous (sea water, brines etc.) or oxidic in nature (dolomite, magnesite, etc.). Regardless of the starting material, the final product must be either solid or molten $\mathrm{MgCl}_{2}$, in order to be fed to the electrolysis cell. The two methods which exist to achieve this objective are: Method (1): convert the material to a saturated solution of $\mathrm{MgCl}_{2}$ and dehydrate it, or Method (2): convert the material to an oxide and then chlorinate it to the anhydrous salt. 
Method $(1)$ is almost universally used when starting with aptuenus ficd stocks thrines. sea

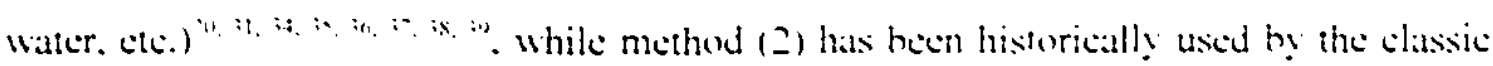
I.C. Farben process"s and more recenty by Magc an in Alhertat Canada" .

Two commercial flow shets. those of Magcorp formerly AMAX and also formerly National Lead) and MagCan will be used to illustrate these two methods.

\subsubsection{Magcorp - feed preparation 3.3 .34}

The Magcorp flow sheet is presented in Figure $f^{: 0}$. The main steps are:

1. pre-concentration of the aqueous feed stock.

2. brine puritication to remove impurities such as sulphate and boron.

3. primary dehydration. and

4. secondary dehỹdration by melting and chlorinating.

This is represented by Steps $1+4$ in Figure 4 .

The raw material for Magcorp. is brine from the Great Salt Lake. Pre-concentration is accomplished mainly by the use of solar ponds that increase the magnesium concentration from 0.4 to 7.5 weight percent ${ }^{30}$.

Brine purification is accomplished by adding $\mathrm{CaCl}_{2}$ to the liquor to precipitate gypsum. which is removed in a thickener. Boron is a particularly detrimental impurity if present during magnesium electrolysis. Oxides of boron tend to stick on the surface of the liquid magnesium metal formed during electrolysis. preventing it from coalescing and potentially causing it to sink ${ }^{\circ}$. Over $99 \%$ of the boron is removed by Magcorp using solvent extraction ${ }^{37}$. 


\section{MAGCORP'S SIX PART PROCESS OF MAGNESIUM}

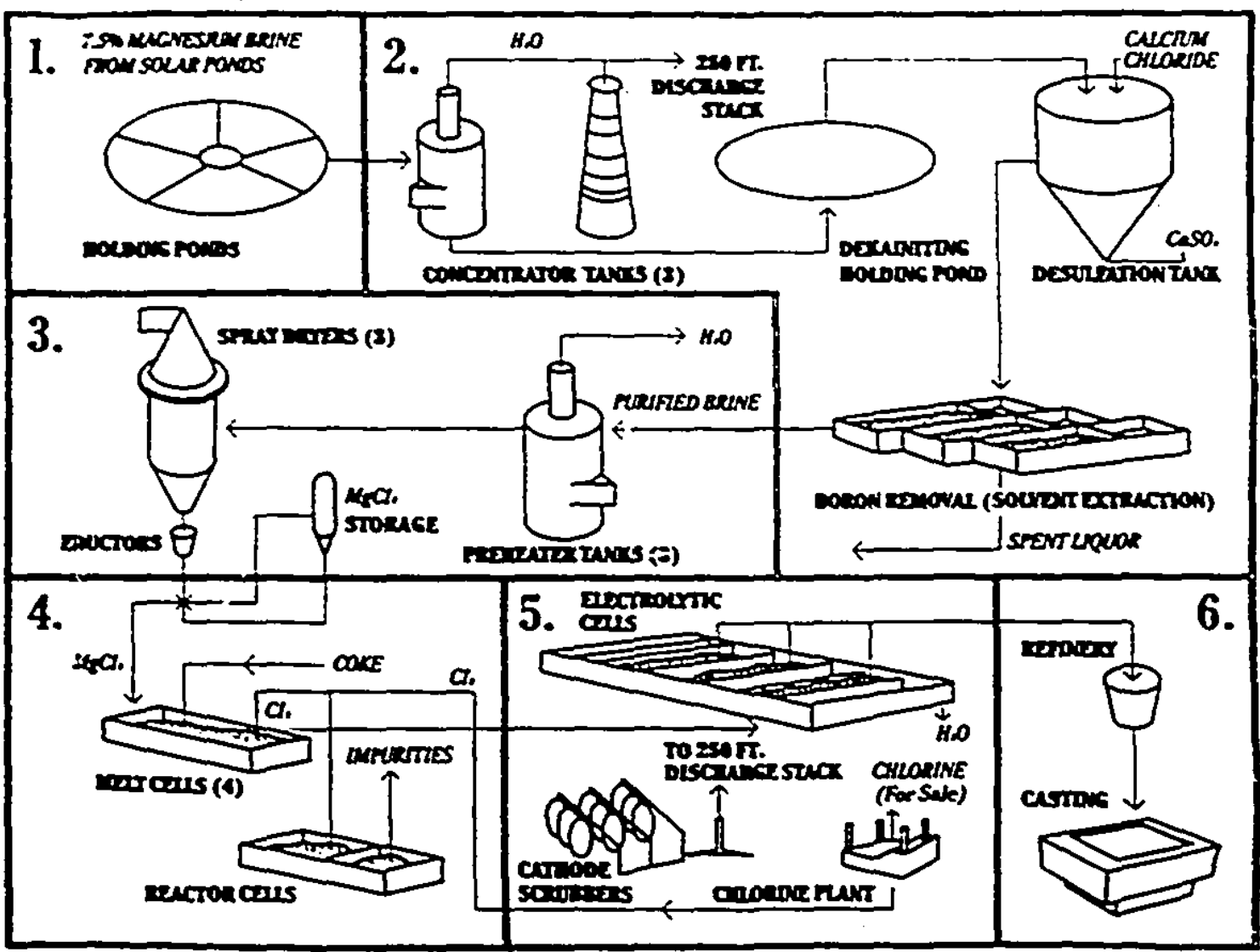

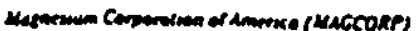

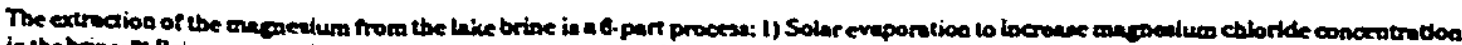

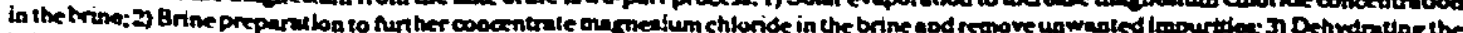

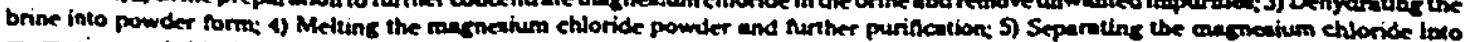

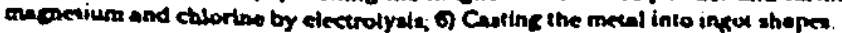

Figure 4: Magcorp's Magnesium Process ${ }^{30}$ 
Primary dehydration is accomplished by first pre-heating the brine and then spray dñing it. Typical composition of a spray dried $\mathrm{MgCl}_{2}$ powder (formed by brine from the Great Salt Lake) is given in Table t". $^{\prime \prime}$

Table 4: Typical Composition of Spray Dried Magnesium Chloride"

\begin{tabular}{cc}
\hline Salt & Wight Percent \\
\hline $\mathrm{MgCl}:$ & $\$ 1.52$ \\
$\mathrm{KCl}$ & 1.08 \\
$\mathrm{NaCl}$ & 1.50 \\
$\mathrm{CaCl}_{2}$ & 3.07 \\
$\mathrm{CaSO}_{2}$ & 0.50 \\
$\mathrm{LiCl}_{2}$ & 1.56 \\
$\mathrm{Na}_{4} \mathrm{O}$ & 0.47 \\
$\mathrm{MgO}$ & 5 \\
$\mathrm{H}_{2} \mathrm{O}$ & 5 \\
\hline
\end{tabular}

The $\mathrm{MgO}$ and $\mathrm{H}_{2} \mathrm{O}$ listed in Table t, are more likely $\mathrm{MgCl}_{2}{ }^{*} \mathrm{H}_{2} \mathrm{O}$ and $\mathrm{Mg}(\mathrm{OH}) \mathrm{Cl}$ as will become apparent in Section 2.1.2.3. It should be noted that spray drying is a nonequilibrium process. The thermodynamics of dehydration as applied to various processes will also be discussed in Section 2.1.2.3.

The spray dried material contains too much water and oxide to be fed to the modern. sealed electrolysis cells that are used by Magcorp. An electrically heated molten salt chlorinator is used to eliminate the last of the water and oxide. Chlorine gas from electrolysis and carbon are reacted in the chlorinator with $\mathrm{MgO}$ and $\mathrm{H}_{2} \mathrm{O}$ according to the following reactions:

$$
\begin{aligned}
& \mathrm{MgO}+\mathrm{C}+\mathrm{Cl}_{2(\mathrm{~s})}=\mathrm{MgCl}_{2(1)}+\mathrm{CO}_{(\mathrm{g})} \\
& \Delta \mathrm{G}^{0}(2)=-198.4 \mathrm{~kJ} / \mathrm{mol} \text { at } 820^{\circ} \mathrm{C}^{-\mathrm{s}} \\
& \mathrm{H}_{2} \mathrm{O}_{(\mathrm{s})}+\mathrm{C}+\mathrm{Cl}_{2(\mathrm{~s})}=2 \mathrm{HCl}_{(\mathrm{s})}+\mathrm{CO}_{(\mathrm{s})} \\
& \Delta G^{0}(\hat{j}) \quad=\quad-223.6 \mathrm{~kJ} / \mathrm{mol} \text { at } 820^{\circ} \mathrm{C}^{2}
\end{aligned}
$$


For $\mathrm{MgO}$ and $\mathrm{C}$ to react according :o Reaction(2), a dissolved oxygen or oxide intermediate must be involved. It is possible that Reaction (2) progresses in the following stages:

\begin{tabular}{|c|c|c|c|c|c|}
\hline & $\mathrm{MgO}$ & & $=$ & $\mathrm{Mg}^{2 *}$ & $+\mathrm{O}^{2-}$ \\
\hline & $\mathrm{O}^{2 \cdot} \quad+$ & $\mathrm{Cl}_{2(\mathrm{~d})}$ & $=$ & $0.5 \mathrm{O}_{2(\mathrm{~d})}$ & $+2 \mathrm{Cl}^{-}$ \\
\hline or & $\mathrm{MgO}+$ & $\mathrm{Cl}_{2(\mathrm{~d})}$ & $=$ & $\mathrm{MgCl}_{2(1)}$ & $+0.5 \mathrm{O}_{2(\mathrm{~d})}$ \\
\hline & $\Delta G^{0}(6)$ & & $=$ & $9.893 \mathrm{~kJ}$ & at $820^{\circ} \mathrm{C}^{25}$ \\
\hline then & $0.5 \mathrm{O}_{2(\mathrm{~d})}+$ & C & $=$ & $\mathrm{CO}_{(\mathrm{k})}$ & \\
\hline & $\Delta G^{0}(7)$ & & $=$ & -208.32 & rol at $820^{\circ} \mathrm{C}^{25}$ \\
\hline and & $0.5 \mathrm{O}_{2(\mathrm{~d})}+$ & $\mathrm{CO}_{(\mathrm{g})}$ & $=$ & $\mathrm{CO}_{2(\mathrm{E})}$ & \\
\hline & $\Delta G^{0}(8)$ & & $=$ & -187.65 & ol at $820^{\circ} \mathrm{C}^{2 \mathrm{~s}}$ \\
\hline
\end{tabular}

The equilibrium partial pressure of oxygen for Reaction (6) can be calculated as follows:

$\begin{array}{llll}\Delta \mathrm{G}^{0} & = & -\mathrm{R} \mathrm{T} \ln \mathrm{K} & {[2]} \\ \mathrm{K}(6) & =0.3367 & \\ \mathrm{~K}(6) & = & \left(\mathrm{P}_{\mathrm{O}_{2}}\right)^{0.5} \mathrm{a}_{\mathrm{MRC}_{2}} / \mathrm{a}_{\mathrm{ME}_{5} \mathrm{O}} \mathrm{P}_{\mathrm{Cl}_{2}} & {[3]} \\ \mathrm{P}_{\mathrm{O}_{2}}(6) & =0.113\left(\mathrm{P}_{\mathrm{C}_{2}}\right)^{2} \text { at } 820^{\circ} \mathrm{C} & {[4]} \\ \mathrm{C}^{*}{ }_{\mathrm{O}_{2}}(6) & =\mathrm{h}_{\mathrm{O}_{2}} \mathrm{P}_{\mathrm{O}_{2}}(6) & {[5]}\end{array}$

At atmospheric pressure, the chlorination of $\mathrm{MgO}$ using pure chlorine gas (Reaction (6)), should generate a $\mathrm{P}_{\mathrm{O}_{2}}$ of about $0.093 \mathrm{~atm}$. (from Equation [4]) and about $9 \%$ efficiency of chlorine use $\mathrm{e}^{25}$ (if equilibrium is approached). The chlorination of $\mathrm{MgO}$ at $800^{\circ} \mathrm{C}$ in a shaft furnace, without reductant, using $80 \%$ chlorine $\left(20 \% \mathrm{~N}_{2}\right)$ has been reported by L.E. Dastolfo $^{\text {4t }}$. During these experiments, which were intended to remove impurities such as iron from $\mathrm{MgO}, 0.1-6.3 \%$ of the $\mathrm{MgO}$ was lost due to an undesired chlorination reaction. 
The fraction of the $\mathrm{MgO}$ reacted in a given time increased almost linearly from 500 to $800^{\circ} \mathrm{C}$ and was apparently determined by diffusion and not the thermodynamic equilibria below $800^{\circ} \mathrm{C}^{41}$.

The Henry's law constant for chlorine gas in cell electrolyte at $750^{\circ} \mathrm{C}$ is reported to be 0.8 $\mathrm{mol} / \mathrm{m}^{3} / \mathrm{atm}^{42}$ (about $36 \%$ as high as high as that of oxygen in water at $0^{\circ} \mathrm{C}^{43}$ ) and is reported to increase with temperature ${ }^{20}$. If the solubility of oxygen is taken to be of the same order of magnitude as chlorine, then at a steady state $\mathrm{Cl}_{2}$, pressure of 0.2 atm for Reaction (2), the maximum dissolved oxygen will be $3.6 \times 10^{-3} \mathrm{~mol} / \mathrm{m}^{3}$. The density of $\mathrm{MgCl}_{2}$ is reported to change as a function of absolute temperature $(\mathrm{K})$ according to ${ }^{27}$ :

$$
\rho_{\mathrm{MgCl}} \quad=\quad 1.976-0.302 \times 10^{-3} \mathrm{~T}
$$

With a $\mathrm{MgCl}_{2}$ density of $1667 \mathrm{~kg} / \mathrm{m}^{3}$ at $750^{\circ} \mathrm{C}$, the dissolved oxygen content would represent a weight fraction of about $6.8 \times 10^{-8}$. The magnitude of the solubility of $\mathrm{MgO}$ in molten chlorides is on the order of $10^{-4}$ weight percent ${ }^{19.4}$ (or an $\mathrm{O}^{2-}$ weight fraction of about $4 \times 10^{-7}$ ). Provided that sufficient $\mathrm{MgO}$ surface area is available for dissolution, the oxide weight fraction should remain an order of magnitude higher than the dissolved oxygen weight fraction, and it is therefore assumed that the separate Reactions (4) and (5) rather than Reaction (6) will be predominant. This mechanism would imply that Reaction (5) would occur near the gas bubbles and probably within the stagnant boundary layer (given the assumption of oxide saturation).

The $\mathrm{Cl}_{2}$ must dissolve in the liquid $\mathrm{MgCl}_{2}$ in order to react, as shown in Reactions (5) and (6). Magcorp uses graphite lances to inject the chlorine gas into the molten electrolyte of the chlorinator. The lances generate large gas bubbles with low surface to volume ratios, resulting in poor mass transfer and low chlorine efficiency (requiring more chlorine than the electrolysis cells produce). Iron or iron salts are added to the bath to increase the mass transfer of the chlorine gas by 1-2 orders of magnitude by the following reactions: 


$$
\begin{aligned}
& \mathrm{FeCl}_{3(1)}+0.5 \mathrm{Cl}_{3(\mathrm{k})}=\mathrm{FeCl}_{3(1)} \\
& \Delta G^{0}(9) \quad=\quad-5.4 \mathrm{~kJ} / \mathrm{mol} \text { at } 820^{\circ} \mathrm{C}^{2 \mathrm{~s}}
\end{aligned}
$$

The apparent liquid phase mass transfer coefficient will be dramatically increased for chlorine by chemical enhancement from Reaction (9) in the diffusion boundary layer surrounding the gas bubbles. Gas to liquid mass transfer will be dealt with in detail in a Chapter 3.

Reaction (9) is easily reversible, and thus 2 moles of $\mathrm{FeCl}_{3}$ can substitute for 1 mole of chlorine in Reactions (2) or (3) as indicated below:

$$
\begin{array}{ll}
2 \mathrm{FeCl}_{2(1)}+\mathrm{Cl}_{2(\mathrm{~g})} & =2 \mathrm{FeCl}_{3(1)} \\
\mathrm{MgO}+2 \mathrm{FeCl}_{3(1)}+\mathrm{C} & =\mathrm{MgCl}_{2(1)}+2 \mathrm{FeCl}_{2(1)}+\mathrm{CO}_{(\mathrm{g})} \\
\mathrm{H}_{2} \mathrm{O}_{(\mathrm{g})}+2 \mathrm{FeCl}_{3(1)}+\mathrm{C} & =2 \mathrm{HCl}_{(\mathrm{g})}+2 \mathrm{FeCl}_{3(1)}+\mathrm{CO}_{(\mathrm{g})}
\end{array}
$$

Reactions (2) and (3) are obtained by adding Reaction (10) with (11) and (12), respectively.

The Magcorp flow sheet requires an additional processing step, because of the use of this iron "catalyst". As shown in Section 4 of Figure 4, electrolytic reactor cells are required to remove iron from the electrolyte to prevent contamination of the product magnesium with iron. The operation of these electro-stripping cells has been described in the patent literature ${ }^{46}$.

The primary advantages of Magcorp's process include the use of an inexpensive raw material (free brine) and the use of solar energy to reduce the amount of thermal energy required by the proceis. Unfortunately Magcorp is the largest point source of chlorine emissions in the United States, releasing 7\% of the total U.S. emission of chlorine into the environment ${ }^{39}$. This is due to the low efficiency $(<70 \%)$ of their chlorination reactor ${ }^{45}$. 


\subsubsection{MagCan - feed prenaration}

MagCan (now closed due to financial difficulties) used high grade magnesite as the raw material for their process. which was based on technology owned by the Minerals Processing Licensing Corporation (M.P.L.C.).

Lump magnesite ore was purchased from the Baymag (Alberta) magnesite deposit. which is one of the largest and purest in the world ${ }^{47.48}$. After careful sizing, the magnesite was charged to a shaft reactor. The burden of this reactor was supported on a bed of coke, which was electrically heated when the unit was not in operation.

The magnesite that was added to the top of the reactor decomposed and reacted with carbon monoxide and chlorine gas. that were injected into the bottom of the reactor. according to the following reactions:

$\begin{array}{lll}\mathrm{MgCO}_{3} & =\mathrm{MgO}+\mathrm{CO}_{2(\mathrm{k})} \text { (13) } \\ \Delta \mathrm{G}^{0}(13) & =0 \text { at } 307^{\circ} \mathrm{C}^{25} \\ \Delta \mathrm{H}^{0}(13) & =99.26 \mathrm{~kJ} / \mathrm{mol} \text { at } 307^{\circ} \mathrm{C}^{25} \\ \mathrm{MgO}+\mathrm{Cl}_{2(\mathrm{~g})}+\mathrm{CO}_{(\mathrm{g})} & = & \mathrm{MgCl}_{2(\mathrm{l})}+\mathrm{CO}_{2(\mathrm{k})}(14) \\ \Delta \mathrm{G}^{0}(14) & = & -177.8 \mathrm{~kJ} / \mathrm{mol} \text { at } 820^{\circ} \mathrm{C}^{25} \\ \Delta \mathrm{H}^{0}(14) & = & -268.28 \mathrm{~kJ} / \mathrm{mol} \text { at } 820^{\circ} \mathrm{C}^{25}\end{array}$

The solid $\mathrm{MgO}$ particles became coated with liquid $\mathrm{MgCl}_{2}$ as Reaction (14) progressed. Therefore, like the Magcorp chlorinator, the rate of chlorination in a shaft furnace should be determined by the rate of mass transfer of the gaseous reagents through the liquid phase.

If $\mathrm{CO}$ diffusion through the gas-liquid boundary layer is rate limiting, then increased $\mathrm{CO}$ partial pressures would result in faster overall reaction rates and higher chlorine 
utilization. This is in agreement with the data of D.V. Pruttskov et. al. for Reaction (14). conducted in a shaft furnace. These data indicated a slightly higher reaction rate at a 2:1 ratio of $\mathrm{CO} / \mathrm{Cl}_{2}$ and increasing utilization of chlorine gas with even higher ratios of $\mathrm{CO} / \mathrm{Cl}_{2}$ as shown in Figure $5^{49}$.

The product of MagCan's chlorination process was molten anhydrous magnesium chloride, which could be tapped from the reactor and fed directly to electrolysis cells. Diaphragmless V.A.M.I. cells, obtained from the bankrupt American Magnesium Company, were used to perform the electrolysis.

Strong similarities exist between the MagCan and the old I.G. Farben processes. In both the MagCan and I.G. processes, oxidic magnesium compounds are chlorinated using chlorine gas in an electrically heated shaft furnace ${ }^{6.34}$. In the I.G process, precipitated $\mathrm{Mg}(\mathrm{OH})_{2}$ is converted to $\mathrm{MgO}$, and pelletized with coke prior to chlorination. These processes are distinguished by the type of reducing agent (carbon monoxide by MagCan and coke in the I.G. process) and the source of the magnesium oxide.

It is rumored that early start-up problems, related to the scale-up of the shaft reactor, caused the company financial hardship, in spite of having operated several chlorinators at smaller scales. These scale-up problems were due to the number of phenomena occurring within the shaft, which included:

1) heat transfer endothermic Reaction (13) occurred at the top of the shaft, exothermic Reaction (14) in the middle and reagent $\left(\mathrm{Cl}_{2}, \mathrm{CO}\right)$ preheating at the bottom,

2) mass transfer gas $\left(\mathrm{CO}, \mathrm{Cl}_{2}, \mathrm{CO}_{2}\right)$ to liquid $\left(\mathrm{MgCl}_{2}\right)$,

3) fluid dynamics gases $\left(\mathrm{Cl}_{2}, \mathrm{CO}, \mathrm{CO}_{2}\right)$ flowed up the shaft counter current to the liquid $\mathrm{MgCl}_{2}$, through a porous bed of solid $\mathrm{MgO} / \mathrm{MgCO}_{3}$, and

4) reaction kinetics chlorination Reaction (14).

The difficulty in scaling a process as complex as this, should not be underestimated. 


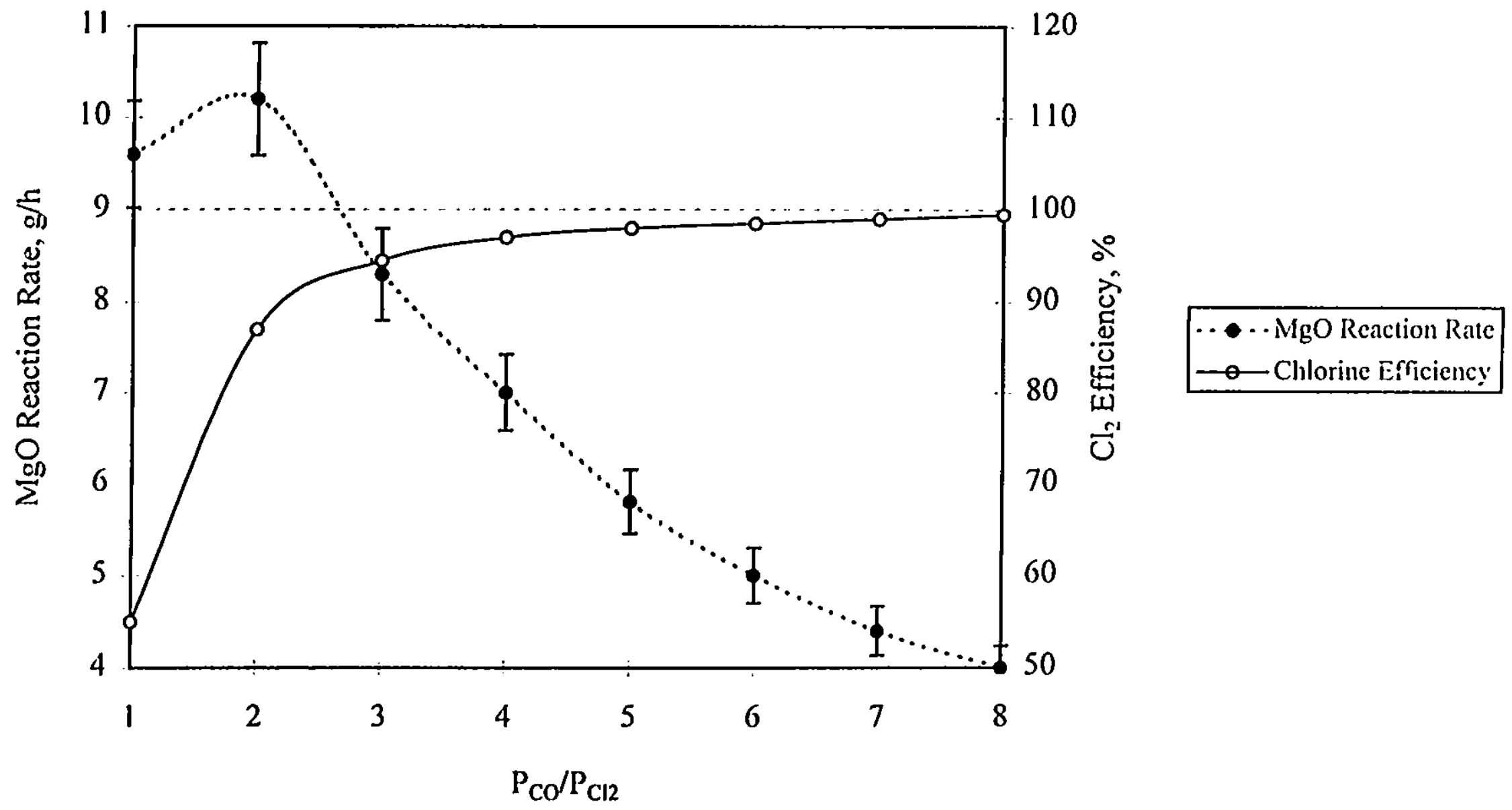

Figure 5: $\mathrm{MgO}$ Reaction Rate and Chlorine Utilization Against Ratio of $\mathrm{P}_{\mathrm{Co}} / \mathrm{P}_{\mathrm{Cl}_{2}}{ }^{49}$ 


\subsubsection{Thermodynamic Considerations of Magnesium Chloride Delyvdration}

The primary difficulty in using magnesium chloride is its affinity for water and its tendency to decompose into $\mathrm{MgO}$ and $\mathrm{HCl}$ during dehydration and melting. A saturated $\mathrm{MgCl}_{2}$ solution at room temperature $\left(542 \mathrm{gpL}^{30}\right.$ ) is in equilibrium with $\mathrm{MgCl}_{2} * 6 \mathrm{H}_{2} \mathrm{O}$ as shown in the $\mathrm{MgCl}_{2}-\mathrm{H}_{2} \mathrm{O}$ phase diagram (Figure $6^{1}$ ). The thermodynamics governing the dehydration of $\mathrm{MgCl}_{2}^{*} 6 \mathrm{H}_{2} \mathrm{O}$ are given in Table $5^{* 3}$.

Table 5: Thermodynamics of Magnesium Chloride Dehydration"s

\begin{tabular}{|c|c|c|c|c|c|}
\hline $\begin{array}{l}\mathrm{MgCl}_{2}^{*} 6 \mathrm{H}_{2} \mathrm{O} \\
\Delta \mathrm{G}^{0}(15)\end{array}$ & $\begin{array}{l}= \\
=\end{array}$ & $\begin{array}{l}\mathrm{MgCl}_{2} * 4 \mathrm{H}_{2} \mathrm{O} \\
0 \text { at } 150^{\circ} \mathrm{C}\end{array}$ & + & $2 \mathrm{H}_{2} \mathrm{O}_{(\mathrm{g})}$ & (15) \\
\hline $\begin{array}{l}\mathrm{MgCl}_{2}^{*} 4 \mathrm{H}_{2} \mathrm{O} \\
\Delta \mathrm{G}^{0}(16)\end{array}$ & $\begin{array}{l}= \\
=\end{array}$ & $\begin{array}{l}\mathrm{MgCl}_{2} * 2 \mathrm{H}_{2} \mathrm{O} \\
0 \text { at } 1911^{\circ} \mathrm{C}\end{array}$ & + & $2 \mathrm{H}_{2} \mathrm{O}_{(\mathrm{k})}$ & (16) \\
\hline $\begin{array}{l}\mathrm{MgCl}_{2} * 2 \mathrm{H}_{2} \mathrm{O} \\
\Delta \mathrm{G}^{0}(17)\end{array}$ & $\begin{array}{l}= \\
=\end{array}$ & 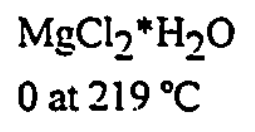 & + & $\mathrm{H}_{2} \mathrm{O}_{(\mathrm{k})}$ & (17) \\
\hline $\begin{array}{l}\mathrm{MgCl}_{2}{ }^{*} \mathrm{H}_{2} \mathrm{O} \\
\Delta \mathrm{G}^{0}(18)\end{array}$ & $=$ & $\begin{array}{l}\mathrm{MgCl}_{2} \\
0 \text { at } 327^{\circ} \mathrm{C}\end{array}$ & + & $\mathrm{H}_{2} \mathrm{O}_{(\mathrm{k})}$ & (18) \\
\hline $\begin{array}{l}\mathrm{MgCl}_{2} * \mathrm{H}_{2} \mathrm{O} \\
\Delta \mathrm{G}^{0}(19)\end{array}$ & $\begin{array}{l}= \\
=\end{array}$ & $\begin{array}{l}\mathrm{Mg}(\mathrm{OH}) \mathrm{Cl} \\
0 \text { at } 298^{\circ} \mathrm{C}\end{array}$ & + & $\mathrm{HCl}_{(\mathbb{k})}$ & (19) \\
\hline $\begin{array}{l}\mathrm{Mg}(\mathrm{OH}) \mathrm{Cl} \\
\Delta \mathrm{G}^{0}(20)\end{array}$ & $\begin{array}{l}= \\
=\end{array}$ & $\begin{array}{l}\mathrm{MgO} \\
0 \text { at } 564^{\circ} \mathrm{C}\end{array}$ & + & $\mathrm{HCl}_{(\mathrm{g})}$ & (20) \\
\hline
\end{tabular}




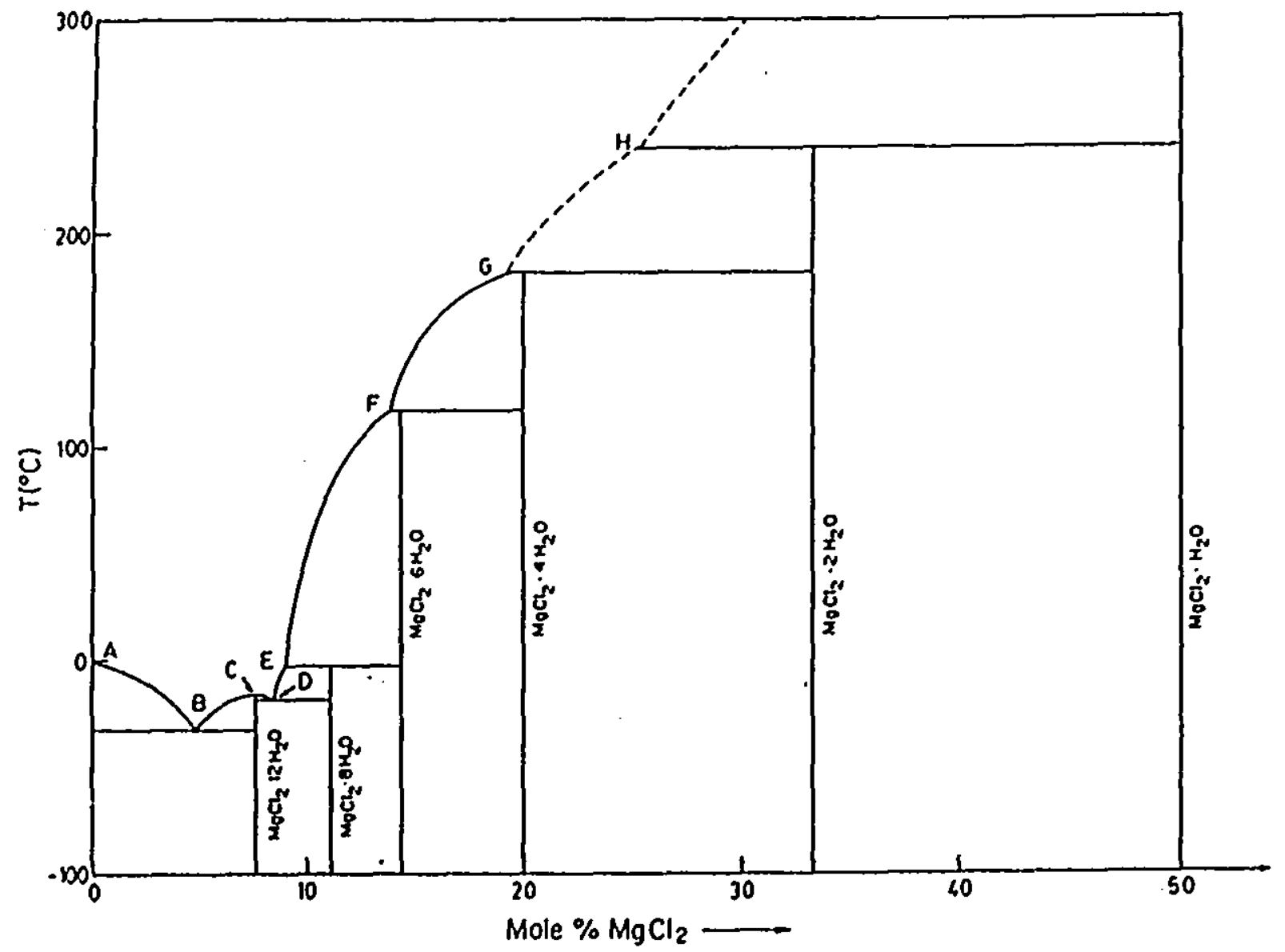

IEGEHD

$\mathrm{MgCl}_{2} \quad\left({ }^{\circ} \mathrm{C}\right)$

$A 0$. 0 .

$\begin{array}{lll}B & 4.9 & .33 .6\end{array}$

$\begin{array}{lll}\text { C } & 7.7 \quad .16 .4\end{array}$

D $\quad 8.0 \quad .16 .8$

E $\quad 9.0 \quad .3 .4$

F $13.9 \quad 116.7$

G 19.2181 .5

H 240

Figure 6: $\mathrm{MgCl}_{2}-\mathrm{H}_{2} \mathrm{O}$ Phase Dingram' 
It is clear from Table 5 that the dehydration of magnesium chloride will progress smoothly from the hexahydrate to the dihydrate: however. it is also clear that the monohydrate will preferentially decompose to the hydroxychloride of magnesium. Any hydroxychloride formed will decompose to magnesium oxide upon melting. Therefore. if magnesium chloride is dehydrated under equilibriurn conditions, magnesium oxide is the final product.

The thermodynamics outlined in Table 5 are for standard conditions. The formation of $\mathrm{Mg}(\mathrm{OH}) \mathrm{Cl}$ is not as favourable under other conditions. Data available on the decomposition potential of $\mathrm{MgCl}_{2}$ when mixed with other salts ${ }^{20}$ can be used to calculate the activity and activity coefficients of $\mathrm{MgCl}_{2}$ according to the following equations:

$\begin{array}{lllll}\Delta \mathrm{G} & = & \Delta \mathrm{G}^{0} & +\mathrm{RT} \ln \left(1 / \mathrm{a}_{\mathrm{M}_{\mathrm{K}} \mathrm{C}_{2}}\right) & {[7]} \\ \Delta \mathrm{G} & = & \text {-nFE } & \text { [\$] } \\ \gamma_{i} & = & \mathrm{a}_{\mathrm{i}} / \mathrm{X}_{\mathrm{i}} & {[9]}\end{array}$

Table 6: Calculated Activities of $\mathrm{MgCl}_{2}$ in Mixtures of $\mathrm{MgCl}_{2}$ and $\mathrm{KCl}^{30}$

\begin{tabular}{cccc}
\hline $\mathrm{X}_{\mathrm{M}_{5} \mathrm{CR}^{20}}$ & $\begin{array}{c}\text { Experimental } \\
\left.\text { E.M.F. }{ }^{20} \mathrm{~V}\right)\end{array}$ & $\begin{array}{c}\text { Calculated } \\
\text { Activity }\end{array}$ & $\begin{array}{c}\text { Calculated Activity } \\
\text { Coefficient }\end{array}$ \\
\hline 1.0 & -2.531 & 1.000 & 1.000 \\
0.622 & -2.547 & 0.688 & 1.105 \\
0.496 & -2.600 & 0.199 & 0.401 \\
0.404 & -2.677 & 0.033 & 0.081 \\
0.390 & -2.681 & 0.030 & 0.076 \\
0.298 & -2.764 & 0.004 & 0.014 \\
0.288 & -2.783 & 0.003 & 0.009 \\
0.211 & -2.814 & 0.001 & 0.006 \\
\hline
\end{tabular}

With a $1: 1$ molar ratio of $\mathrm{MgCl}_{2}: \mathrm{KCl}$ as exists with many carnallites, it would be expected from Table 6, that the activity of $\mathrm{MgCl}_{2}$ could be as low as 0.2 . This would suggest that the dehydration of carnallites would be substantially easier than that of pure 
$\mathrm{MgCl}_{2}$. This fact is well known within the magnesium industry and forms the basis for most of the Former Soviet Union countries (F.S.U.) magnesium technology $y^{20}$.

Commercial magnesium processes use a variety of methods to dehydrate the $\mathrm{MgCl}_{2}$. In the Dow process. concentrated magnesium chloride brine is first dehydrated to about 1.5 moles of water per mole of $\mathrm{MgCl}_{2}$ in a fluid bed dryer. The semi-dehydrated $\mathrm{MgCl}_{2}$ powder is fed directly to the electrolysis cell. The reason that this material does not convert directly to $\mathrm{MgO}$ can be seen from the data in Table 6. The activity of $\mathrm{MgCl}_{2}$ in the cell electrolyte is less than about 0.03 . inhibiting the decomposition of the $\mathrm{MgCl}_{2}$. Some $\mathrm{MgO}$ is still produced and some of it subsequently reacts with cell chlorine and electrode carbon to form $\mathrm{MgCl}_{2}$, resulting in the high graphite consumption for the Dow process (see Table 3). The most part of the $\mathrm{MgO}$ forms a sludge (see Table 3) and settles to the bottom of the cell, requiring manual cleaning ${ }^{6}$.

Reactions (18) and (19) indicate that an atmosphere of nearly pure $\mathrm{HCl}$ would allow anhydrous $\mathrm{MgCl}_{2}$ to be produced without the formation of hydroxychloride. The required ratio of $\mathrm{HCl} / \mathrm{H}_{2} \mathrm{O}$ can be calculated from the equilibria of Reaction (21):

$$
\mathrm{MgCl}_{2}+\mathrm{H}_{2} \mathrm{O}_{(\mathrm{g})}=\mathrm{Mg}(\mathrm{OH}) \mathrm{Cl}+\mathrm{HCl}_{(\mathrm{k})}
$$

At $327^{\circ} \mathrm{C}$ with a equilibrium $P_{\mathrm{HCl}} / P_{\mathrm{H} 2 \mathrm{O}}=2.0$. Reaction (21) goes $50 \%$ to completion and at a $P_{\mathrm{HC}} / \mathrm{P}_{\mathrm{HzO}}=20$, Reaction (21) still goes $9.4 \%$ to completion's. While this would appear to be an inefficient way of accomplishing the dehydration of $\mathrm{MgCl}_{2}$, it does in fact form the basis of Norsk-Hydro's new magnesium process, now operating in Canada ${ }^{36}$. The route chosen by Norsk produces dehydrated $\mathrm{MgCl}_{2}$ suitable for electrolysis, while avoiding the formation of chlorinated hydrocarbons during dehydration: a problem that plagued their old plant in Porsgrunn, Norway, that operated the old I.G. Farben process. 


\section{Chapter 3 Chlorination and Stirred Tank Reactors}

The ideal electrolytic magnesium process would produce anhydrous $\mathrm{MgCl}_{2}$ in a single step, while avoiding the difficulties associated with the dehydration of aqueous $\mathrm{MgCl}_{2}$. The chlorination of magnesite with chlorine and carbon monoxide as practised by MagCan, achieves this objective ${ }^{40}$; however, the difficulties of scaling-up a shaft reactor reduce the attractiveness of their process. These difficulties could be reduced by using a stirred tank reactor, since standard chemical engineering techniques could then be used for scale-up. This reactor would be similar to the Magcorp ${ }^{39}$ chlorinator. but would use rotary injectors instead of lances to disperse the gas into the liquid $\mathrm{MgCl}_{2}$ phase.

In the Magcorp chlorinator, the solid $\mathrm{MgO}$ is reacted with solid carbon and gaseous $\mathrm{Cl}_{2}$ in a liquid phase of $\mathrm{MgCl}_{2}$, as shown in Reaction (2):

$$
\mathrm{MgO}+\mathrm{C}+\mathrm{Cl}_{2(\mathrm{~g})} \quad=\quad \mathrm{MgCl}_{2(\mathrm{l})}+\mathrm{CO}_{(\mathrm{k})}
$$

It is the author's conclusion that Reaction (2) is limited by mass transfer of $\mathrm{Cl}_{2}$ from the gas to the liquid phase, based on the behaviour of the Magcorp chlorinator. As explained previously, iron was added to increase the rate of chlorine mass transfer by chemical enhancement of the liquid phase mass transfer coefficient and this was found to increase the overall rate of reaction ${ }^{45}$.

The MagCan Chlorinator requires the transfer of both $\mathrm{Cl}_{2}$ and $\mathrm{CO}$ into the liquid $\mathrm{MgCl}_{2}$ according to Reaction (14):

$$
\mathrm{MgO}+\mathrm{Cl}_{2(\mathrm{~g})}+\mathrm{CO}_{(\mathrm{g})}=\mathrm{MgCl}_{2(\mathrm{l})}+\mathrm{CO}_{2(\mathrm{~g})}
$$

The rate of Reaction (14) has already been shown to be determined by the mass transfer of $\mathrm{CO}^{49}$. The use of iron would not be expected to increase the rate of Reaction (14), since it will have no impact on $\mathrm{CO}$ mass transfer, however, if a rotary gas injector were used, the greater gas/liquid surface area generated per unit gas volume, would increase both $\mathrm{Cl}_{2}$ and $\mathrm{CO}$ transfer rates and also eliminate the requirement to use a catalyst. 


\subsection{Rotary Gas Injectors}

A rotary gas injector is essentially a combination of a shaft/urbine. with a gas sparger. The process gas is injected directly through a bore in the shafi. instead of through a separate gas sparger. This eliminates the requirement for a gas sparger below the impeller, which in many pyrometallurgical applications is not practical.

The choice of material from which to fabricate a rotary injector is limited due to the presence of chlorine and the absence of water. Under these conditions, even metals such as titanium will chemically react (titanium will react violentiy to form $\mathrm{TiCl}_{4}$ ): however. the use of graphite to fabricate rotary gas injectors is well known within the aluminum industry. Several commercial processes (SNIF ${ }^{s 1}$. Alcoa 622 ${ }^{s 2}$. Alpur ${ }^{33}, \mathrm{RDU}^{s 4}, \mathrm{GIFS}^{s s}$, etc.) operate using graphite rotary gas injectors. In these processes, hydrogen. alkali metals and solid inclusions are removed from liquid aluminum and aluminum alloys, by fine dispersions of either chlorine or mixtures of chlorine and inert gases $\left(N_{2}, A r\right)$. M. Nilmani. P.K. Thay, and C.J. Simensen have published a review of the performance of the impellers used in these processes ${ }^{56}$.

Rotary gas injectors increase the rate of gas to liquid mass transfer by creating fine bubbles in the vortexes formed at the trailing edge of the impeller blades. This effect is illustrated in Figure $7^{57}$. These fine bubbles are dispersed throughout the vessel by the pumping action of the impeller. 


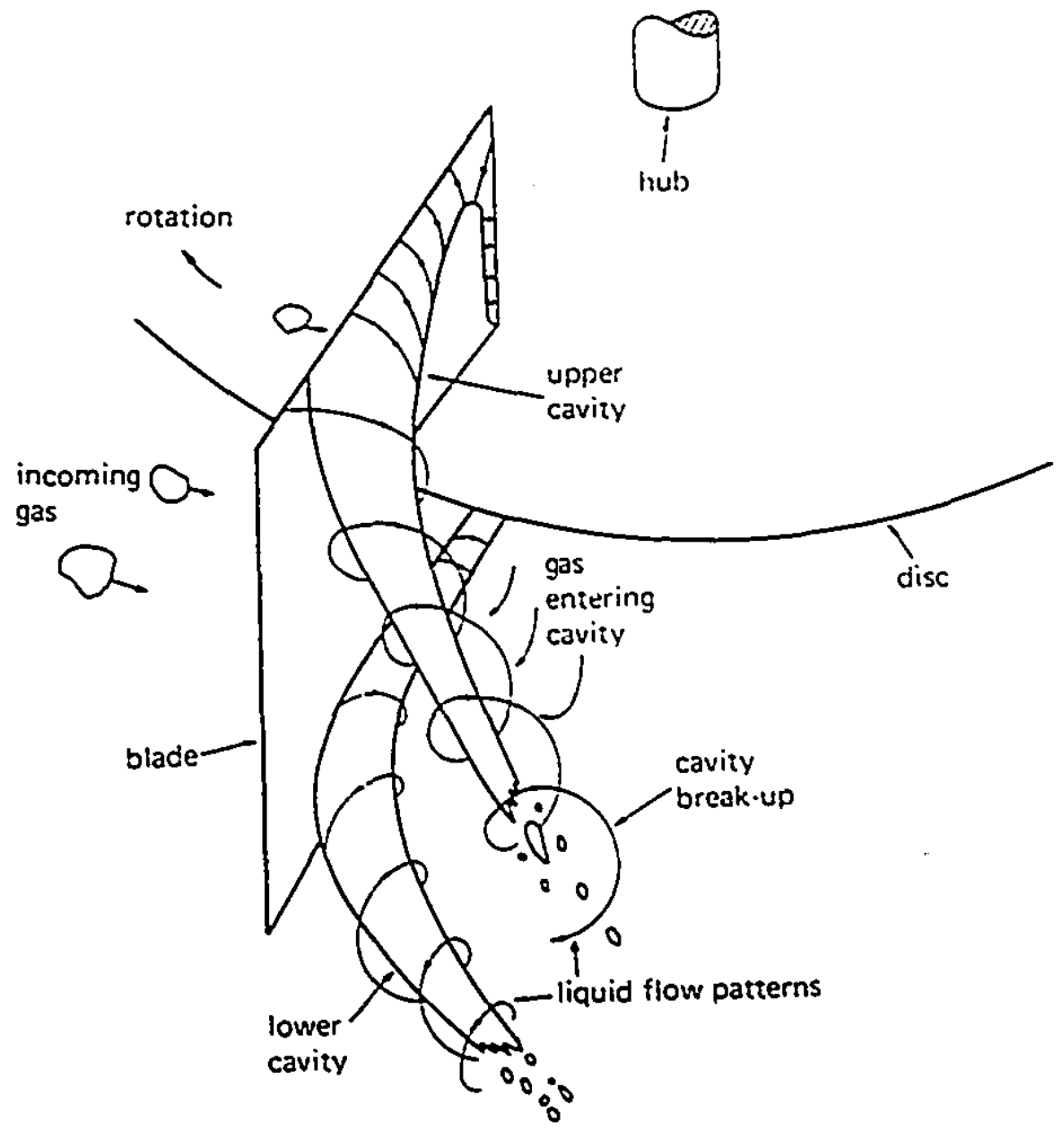

Figure 7: Bubble Formation by Rotating Impellers ${ }^{37}$ 


\subsection{Gas Liquid Mass Transfer in Stirred Tanks}

The apparent kinetics of a mass transfer limited reaction. such as Reaction (14) can be described by the following equations:

$$
\begin{aligned}
& \mathrm{R}=k_{\mathrm{L}_{1}} \mathrm{a}\left(\mathrm{C}_{1}^{*}-\mathrm{C}_{1}\right) \\
& \mathrm{C}_{1}^{*}=\mathrm{h}_{1} \mathrm{P}_{1}
\end{aligned}
$$

Where species (i) is the reactant with the slowest mass transport (low solubility or low diffusivity). The limiting specie for Reaction (14) has aiready been shown to be $\mathrm{CO}^{34}$.

It should be noted that Equation [10] assumes that liquid side mass transfer resistance will predominate. if this is not true, the overall mass transfer coefficient $K_{L}$ must be used instead: $\quad 1 / K_{L}=1 /\left(E k_{G}\right)+1 / K_{L}$

The gas phase mass transfer coefficient $\left(k_{6}\right)$ can become important if sufficient chemical enhancement of the liquid phase coefficient $\left(k_{L}\right)$ occurs. The effect of a chemical reaction on inter-phase diffusion is illustrated in Figure $\mathcal{S}^{\text {ss }}$.

An estimate of the liquid phase mass transfer coefficient (in the absence of chemical enhancement) can be obtained from the following correlation":

$$
\mathrm{N}_{\mathrm{Sh}_{\mathrm{L}}}=\mathrm{k}_{\mathrm{L}} \mathrm{d}_{\mathrm{d}} /\left(c D_{\mathcal{L}}\right)=2.0+0.31 \mathrm{~N}_{\mathrm{R}_{3}}{ }^{1.3}
$$

For spherical gas bubbles (about $1.4 \mathrm{~mm}$ and less ${ }^{59}$ ), the gas-liquid interfacial area per unit liquid volume $\left(\mathrm{m}^{2} / \mathrm{m}^{3}\right)$ can be calculated from the mean bubble diameter and gas hold-up:

$$
\text { a }=6 \varepsilon / d_{b}
$$

Gas hold-up is the fraction of the total dispersion volume occupied by gas:

$$
\varepsilon \quad=\left(V_{1}-V_{1}\right) / v_{1}
$$



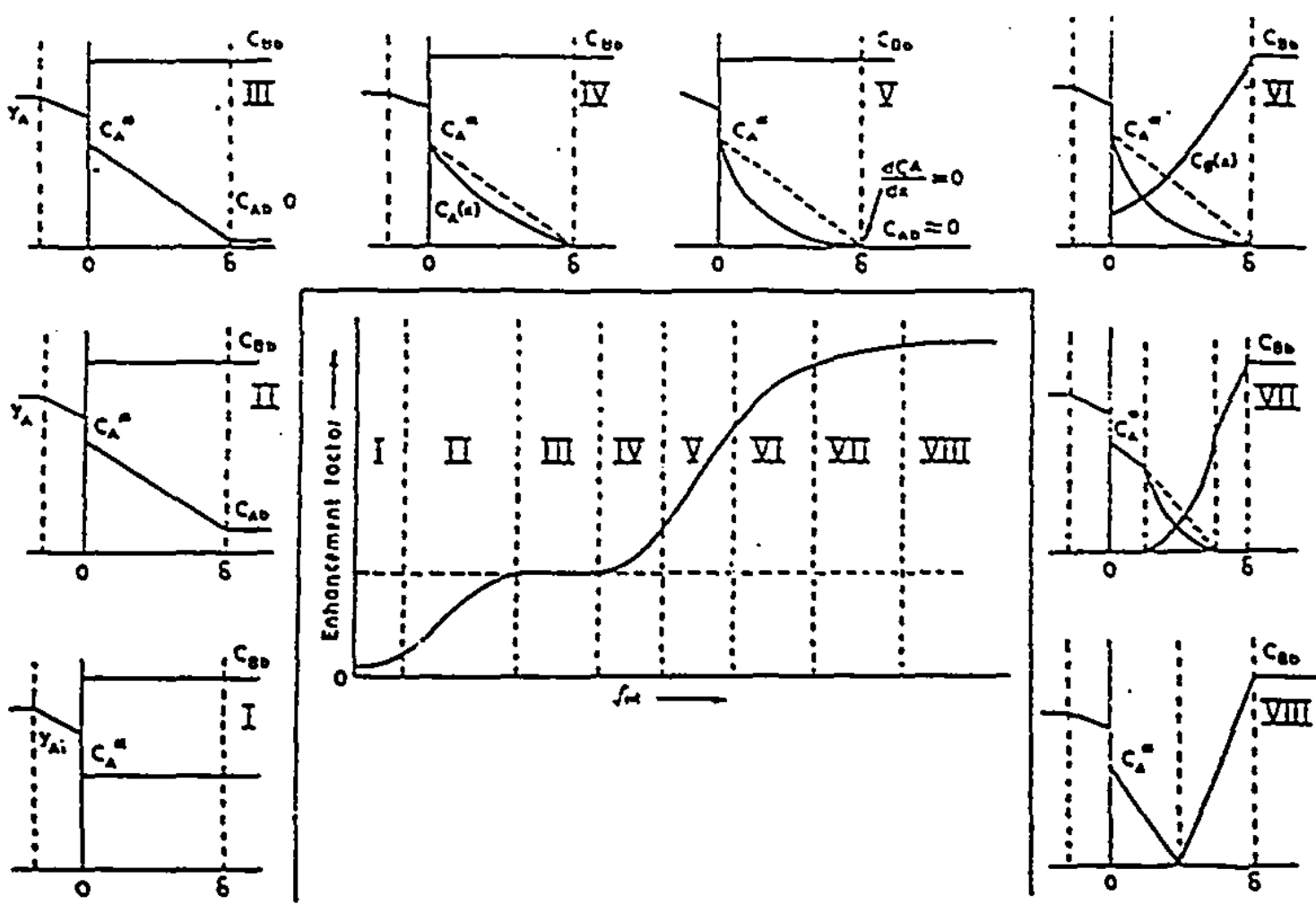

Diffusion - reaction regimes for a simple second urder reaction. 1 - very slow reaction, liquid phase is saturated with $A$. Il - reaction in bulk of liquid makes $C_{A b}<C_{A}{ }^{*}$. no reaction in tilm. III - reaction in bulk makes $C_{A b} \rightarrow 0$, no resetion in film. IV - reaction in film becomes comparsble with buik resction. $V-$ resction confin. ed to film with negligible bulk reaction. VI - consumption of $B$ within the film is signifieant. VII - reaction takes place only in a portion of the film. VIII - seaction becones cunfined to a plane within the film.

Figure 8: Chemical Enhancement of Gas-Liquid Mass Transfer" 
Many correlations of gas hold-up are available in the literature for different types of impellers. Two examples are given below ${ }^{60}$ :

$$
\begin{aligned}
& \varepsilon \quad=17.9\left(\mathrm{P}_{\mathrm{s}} / \mathrm{V}\right)^{0.31}\left(\mathrm{v}_{\mathrm{s}}\right)^{0.67} \\
& \varepsilon \quad=0.52\left(\mathrm{~N}_{2}\right)^{0.5}\left(\mathrm{~N}_{\mathrm{Wc}_{\mathrm{c}}}\right)^{0.65}(\mathrm{D} / \mathrm{T})^{1.4}
\end{aligned}
$$

A more widely used method of estimating $k_{\mathrm{L}}$ and a. for a stirred tank. is to use a correlation of the following form ${ }^{57}$ :

$$
k_{\mathrm{L}} \mathrm{a}=\mathrm{k}\left(\mathrm{P}_{\mathrm{s}} / \mathrm{V}\right)^{\mathrm{x}}\left(\mathrm{v}_{\mathrm{s}}\right)^{\mathrm{y}}
$$

The normal method for obtaining the constants in Equation [18]. is to use a reaction for which the mass transfer driving force $\left(C_{i}^{*}-C_{i}\right)$ in Equation [10] is known. This method was first used by C.M. Cooper. G.A. Fernstrom and S.A. Miller in $1944^{6 !}$. who utilised the copper catalysed oxidation of sodium sulphite by air.

Values for the constants in Equation [18] appear to be dependant on many experimental parameters (impeller and tank geometrys, presence of electrolyte. catalyst used, water quality, etc.) and have varied widely in the literature. Values of the exponentials, $x$ and $y$, have varied from 0.4-0.95 and 0-1, respectively ${ }^{57}$. A review of a large number of researchers by $\mathrm{K}$. Van ${ }^{\top} \mathrm{Rie}{ }^{62}$, suggested values for $\mathrm{x}$ and $\mathrm{y}$ of 0.4 and 0.5 for pure water and 0.7 and 0.2 for electrolyte solutions.

More recently, the use of dissolved gas meters have allowed $\mathrm{k}_{\mathrm{L}} \mathrm{a}$ to be correlated without the use of a chemical reaction. The equations for water-electrolyte (non-coalescing) and pure water (coalescing) systems at $20^{\circ} \mathrm{C}$ are ${ }^{57}$ :

$$
\begin{aligned}
& k_{\mathrm{L}} \mathrm{a}=2.3\left(\mathrm{P}_{\mathrm{L}} / \mathrm{V}\right)^{0.7}\left(\mathrm{v}_{\mathrm{s}}\right)^{0.6} \\
& \mathrm{k}_{\mathrm{L}} \mathrm{a}=1.2\left(\mathrm{P}_{\mathrm{s}} / \mathrm{V}\right)^{0.7}\left(\mathrm{v}_{\mathrm{s}}\right)^{0.6}
\end{aligned}
$$

The reaction rate of a mass transfer controlled reaction can be calculated by combining Equations [10] and [18]:

$$
R=k\left(C_{i}^{*}-C_{i}\right)\left(P_{s} N\right)^{x}\left(v_{s}\right)^{y}
$$


Where the mass transfer driving force $\left(\mathrm{C}_{\mathrm{i}}^{-}-\mathrm{C}_{\mathrm{i}}\right)$ is constant. Equation [21] reduces to:

$$
\mathrm{R}=\mathrm{k}\left(\mathrm{P}_{\mathrm{r}} / \mathrm{V}\right)^{\prime}\left(\mathrm{v}_{\mathrm{y}}\right)^{\mathrm{v}}
$$

Stevens and Yu. used an equation of the form of Equation [22] to correlate the rate of alkali metal chlorination in liquid aluminum using chlorine gas and a rotary gas injector ${ }^{63}$ :

$$
\mathrm{R}=\mathrm{k} \quad\left(\mathrm{N}^{3} \mathrm{D}^{5} / \mathrm{V}\right)^{0.105}\left(\mathrm{v}_{\mathrm{s}}\right)^{\mathrm{t} .14}
$$

In order to obtain the coefficients in Equation [22], for the chlorination of $\mathrm{MgO}$ by $\mathrm{Cl}_{2}$ and $\mathrm{CO}$ in $\mathrm{MgCl}_{2}$, it was necessary to conduct chlorination experiments in a stirred tank. For the results to be of maximum use, the design of this tank was such that it could later be scaled-up with geometric similarity.

\subsubsection{Mixing Power in Stirred Tanks}

The mixing power is required to use Equation [22] and to determine motor size on scaleup. Dimensional analysis of a rotating impeller leads to an equation of the following form for mixing power in the absence of gas ${ }^{64}$ :

$$
P_{0}=N_{p} \rho N^{3} D^{5}\left(N_{R e}\right)^{2}\left(N_{F r}\right)^{b}
$$

In baffled systems the Froude number $\left(\mathrm{N}_{\mathrm{Fr}}\right)$ is not important, since vortex formation is avoided. In Figure 9, the power number $\left(N_{p}\right)$ is plotted against Reynolds number $\left(N_{R c}\right)$ in a baffled tank, for a number of commercial impellers ${ }^{65}$.

Power number is strongly dependant on both tank and impeller geometry and on the location of the impeller within the tank. Of particular importance are the height of the impeller from the bottom (C), the size (b) and number of baffles (n) and the impeller to tank diameter ratio $(D / T)^{66}$. Experimentation will be required to determine the power number $\left(\mathrm{N}_{\mathrm{p}}\right)$ of the graphite rotary gas injector, due to its unique impeller geometry. 


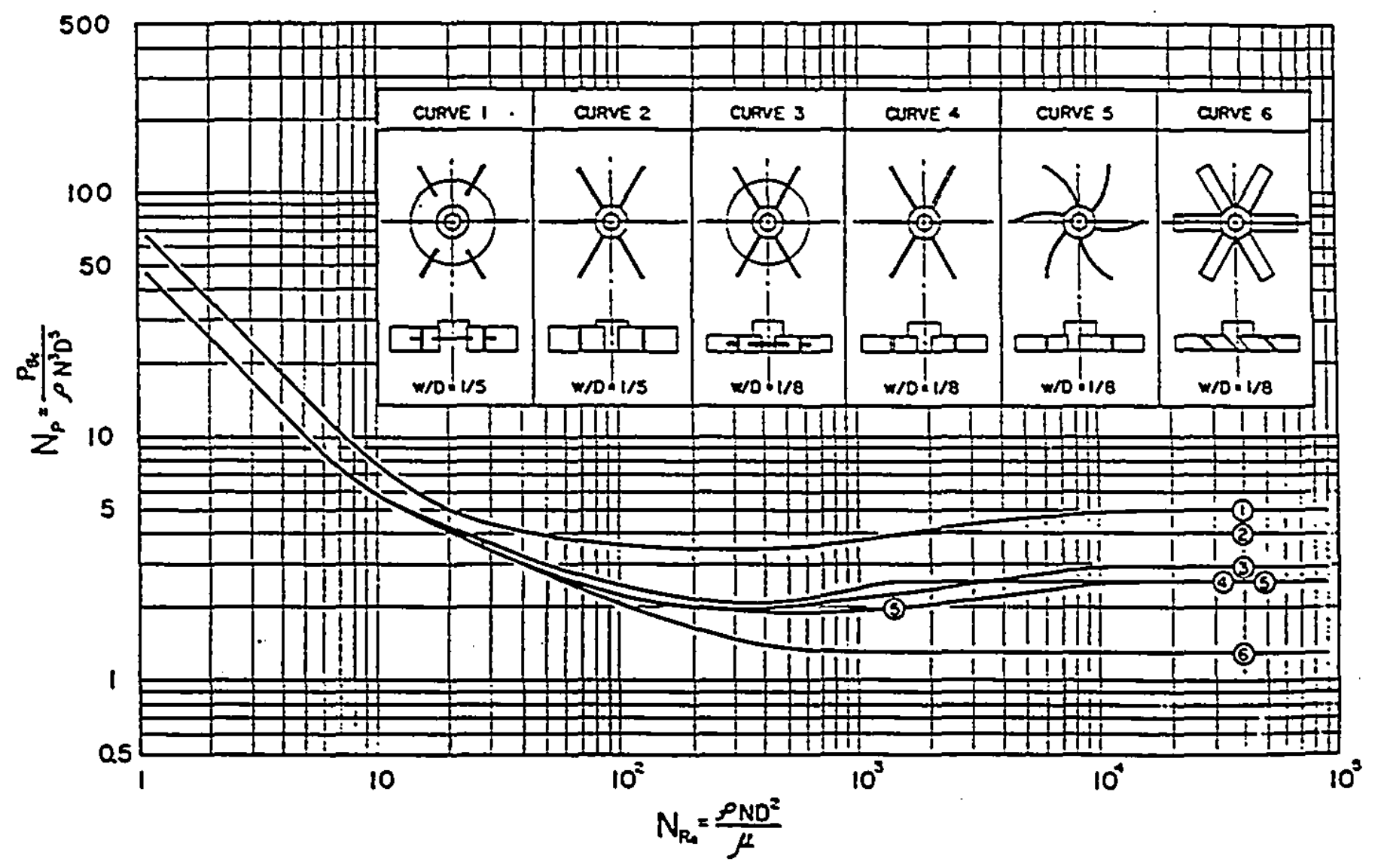

Figure 9: Impeller Power Number Against Reynolds Number ${ }^{65}$ 
When gas is injected into a tank with a rotating impeller, the power required to rotate the impeller generally decreases as shown in Figure $10^{40}$. The effect of gas injection on power consumption is the subject of much research. Two good review papers are those by M. Greaves and M. Barigou ${ }^{60}$ and J.B. Joshi. A.B. Pandit and M.M. Sharma ${ }^{67}$.

While many correlations exist to relate gassed to un-gassed power, the vast majority of these equations incorporate a linear or non-linear correlation with aeration number $\left(\mathrm{N}_{2}\right)$. While the data in Figure 10 is approximated by 2 linear equations, the same data could be correlated by a single equation of the form:

$$
\mathrm{P}_{\mathrm{k}} / \mathrm{P}_{\mathrm{o}} \quad \mathrm{k}\left(\mathrm{N}_{\mathrm{2}}\right)^{\mathrm{c}}
$$

This equation will be used to correlate the gassed power data obtained from thesc experiments. The coefficient for the aeration number has been reported to be between -0.22 and $-0.38^{60.68}$.

Equations [22], [24] and [25] are not valid for all combinations of impeller speeds and gas injection rates. Some combinations of impeller speed and gas injection rates will produce a phenomena known as flooding. Flooding occurs when too much gas is injected for a given rotational rate of the impeller. When flooding occurs, the gas is no longer properly dispersed and extremely large bubbles with low surface to volume ratio appear. The large bubbles result in a dramatic decrease in both gas hold-up and gas-liquid interfacial area.

If a spinning impeller is rotated at a constant speed $\left(N_{1}\right)$ and the gas injection rate is increased, the impeller will flood at a certain gas flow rate $\left(Q_{1}\right)$. If the gas injection rate is maintained at $\left(Q_{1}\right)$ and the rotational speed of the flooded impeller is increased. at some higher speed $\left(\mathrm{N}_{2}\right)$, the impeller will again disperse the gas. 


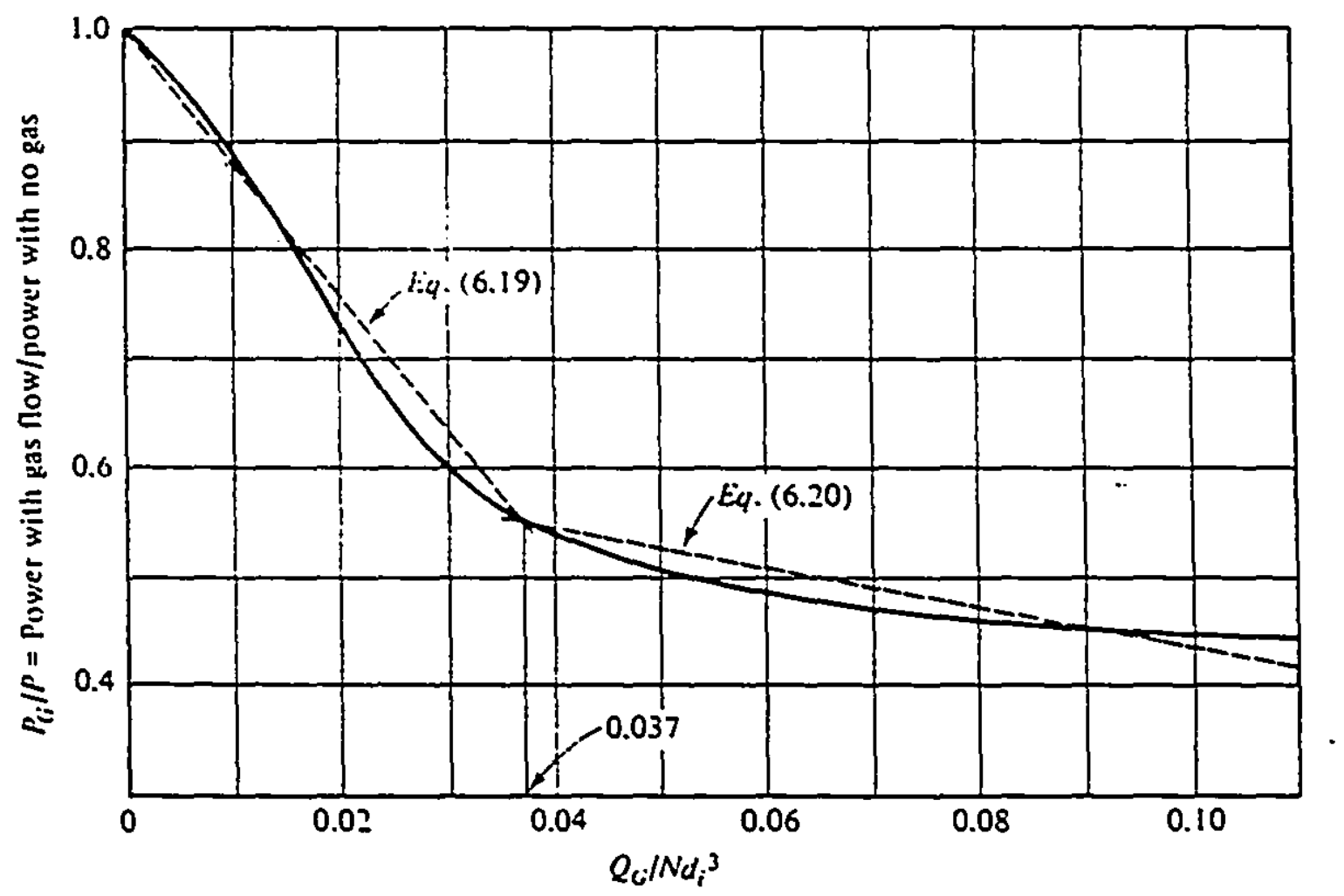

Figure 10: Ratio of Gassed to Un-gassed Power Against Aeration Number ${ }^{59}$ 
If the impeller is operated above $\left(\mathrm{N}_{2}\right)$ at $\left(\mathrm{Q}_{1}\right)$, it will never be flooded and if it is operated below $\left(N_{1}\right)$ at $\left(Q_{1}\right)$ it will always be flooded. Operation between $\left(N_{1}\right)$ and $\left(N_{2}\right)$ could result in either the impeller being flooded or not. This meta-stable flooding phenomena has been plotted by Rushton and Bimbinet ${ }^{69}$ in Figure 11. Care must be taken to avoid operation in the meta-stable area of gas dispersion. Normally from $1-7 \mathrm{~kW} / \mathrm{m}^{3}$ (up to 15 $\mathrm{kW} / \mathrm{m}^{3}$ in small vessels) is sufficient to adequately disperse the gas ${ }^{57}$.

The transition from well dispersed gas to flooding is shown schematically in Figure $12^{57}$. The flow regimes in Figure 12 have been described as follows ${ }^{20}$ :

(a) negligible dispersion (flooded)

(b) upper part of vessel acting as bubble column

(c) gas circulation in the upper part of the vessel, with occasional movement in the lower region

(d) gas circulating throughout the whole vessel

(e) secondary loops form and gross recirculation

For round baffled tanks using Rushton turbines in water:

$\mathrm{N}_{\mathrm{F}}$ is the transition from (a) to (b) and is the minimum speed at which flooding can be avoided ${ }^{71}$ :

$$
\left(N_{2}\right)_{F}=\left(Q / N D^{3}\right)_{F}=30(D / T)^{3.5}\left(N_{F r}\right) \quad \text { [26] }
$$

$\mathrm{N}_{\mathrm{CD}}$ is the transition from (c) to (d) and is the speed at which the minimum ratio of $\mathrm{P}_{\mathrm{s}} / \mathrm{P}_{\mathrm{o}}$ is occurs for a fixed gas injection rate ${ }^{57}$ :

$$
\mathrm{N}_{\mathrm{CD}}=\left(4 \mathrm{Q}^{0.5} \mathrm{~T}^{0.25}\right) / \mathrm{D}^{2}
$$

$N_{R}$ is the transition from (d) to (e) and is the speed at which the peak in the ratio of $P_{R} / P_{0}$ occurs for a fixed gas injection rate ${ }^{57}$ :

$$
\mathrm{N}_{\mathrm{R}}=\left(1.5 \mathrm{Q}^{0.2} \mathrm{~T}\right) / \mathrm{D}^{2}
$$

The ratio of $P_{2} / P_{0}$ is plotted against aeration number $\left(N_{2}\right)$ in Figure $13^{57}$. 


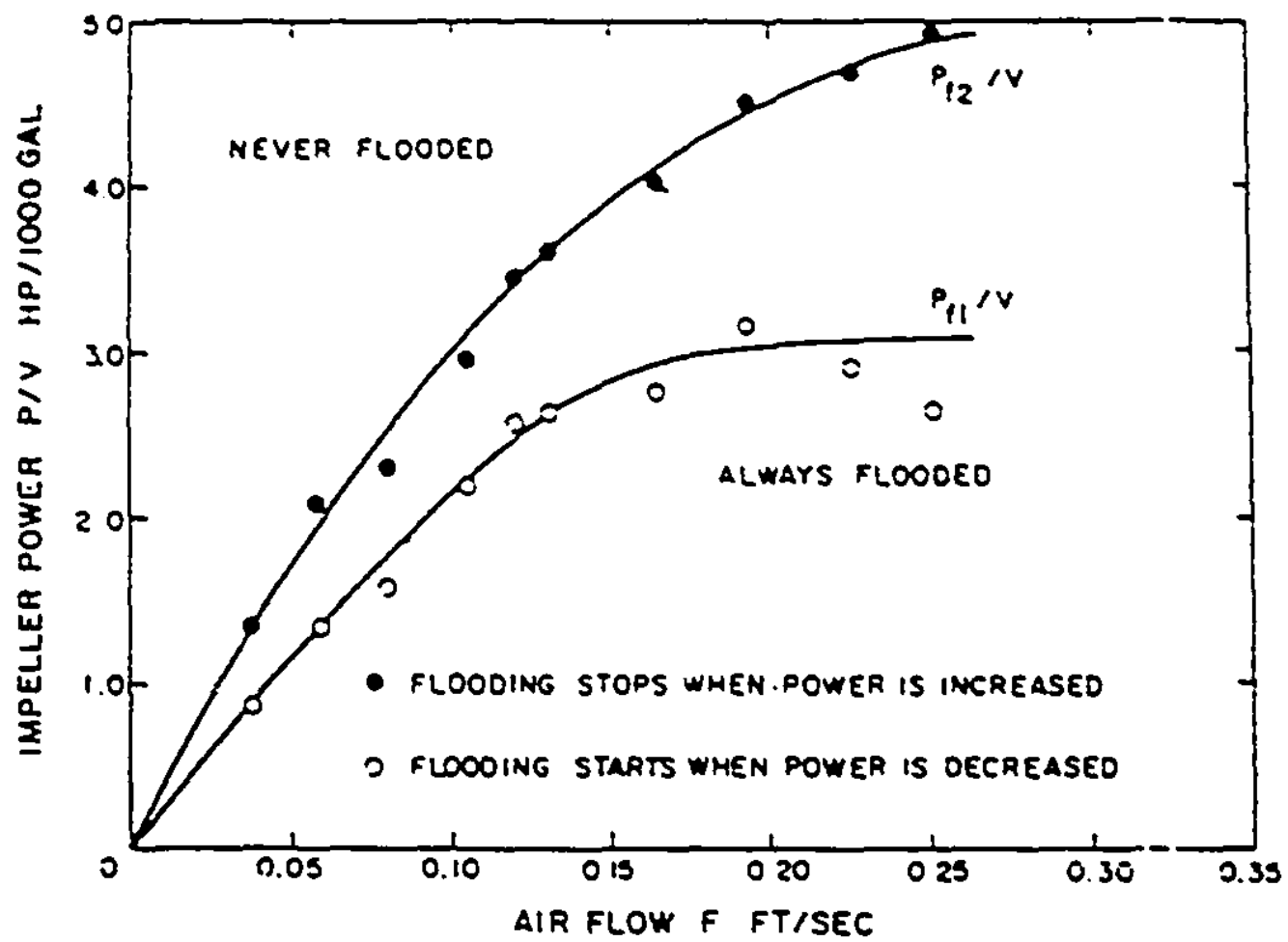

Figure 11: Flooding Curves for Water, $T=12$ ", $D=3^{369}$ 


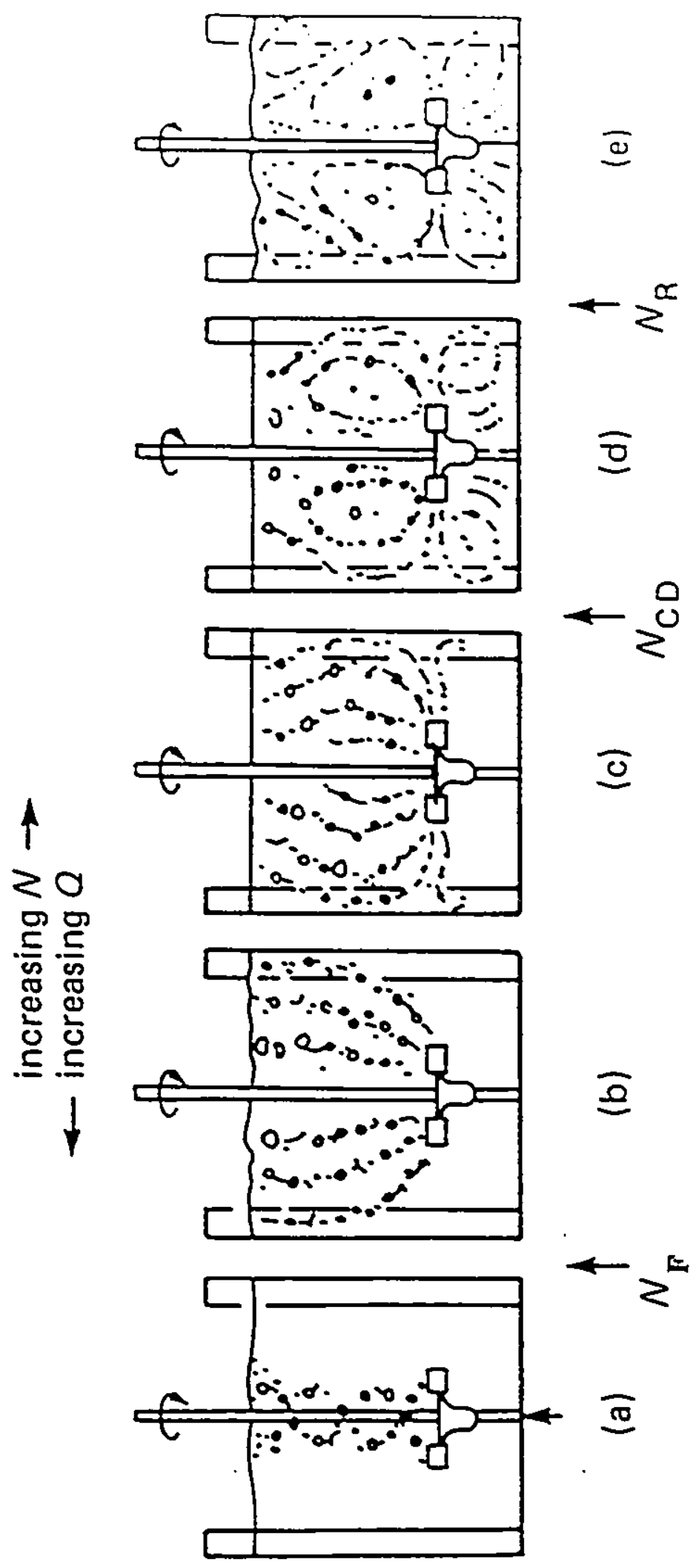

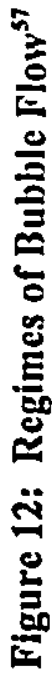

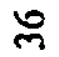




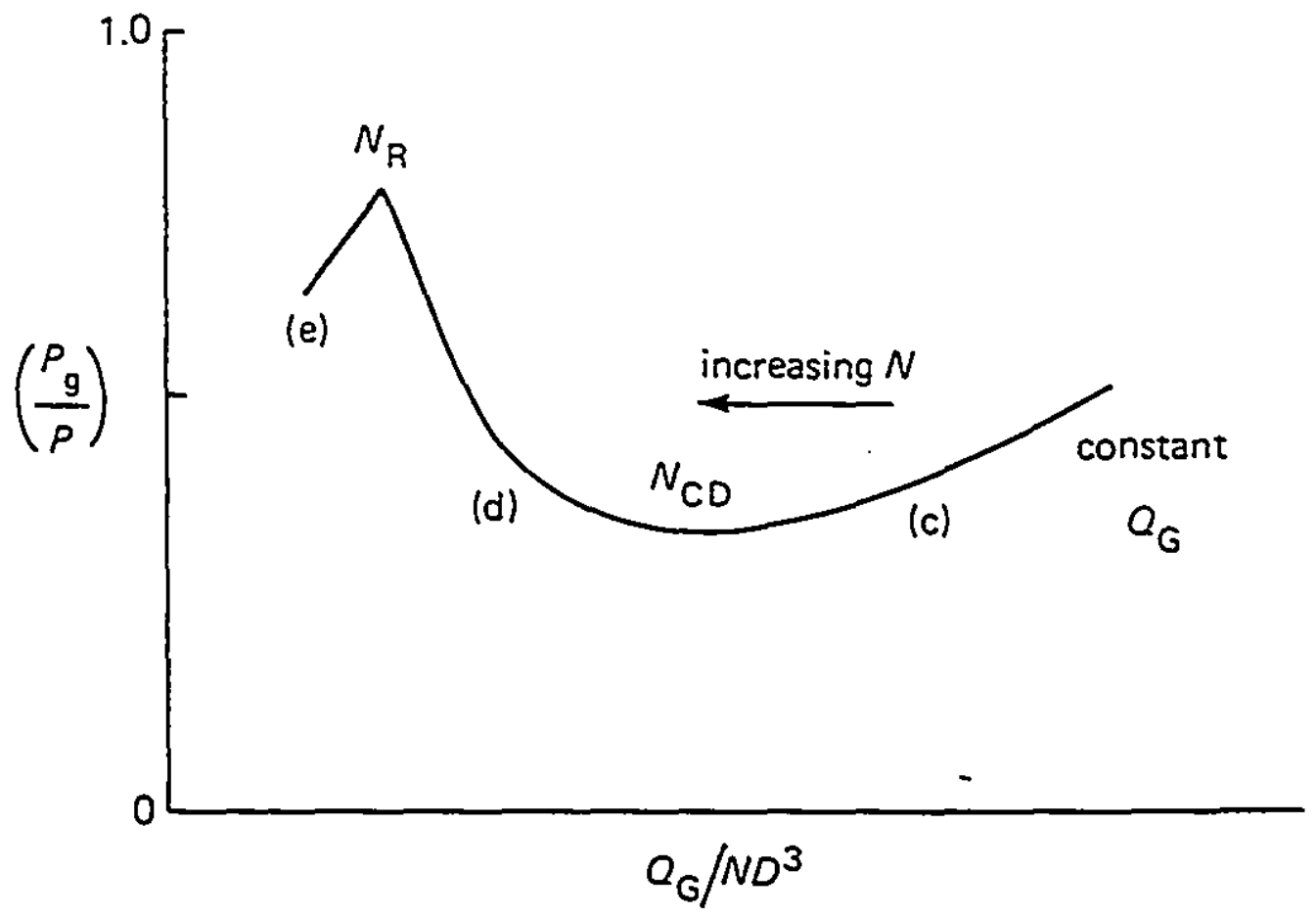

Figure 13: Ratio of $P_{z} P_{0}$ at Constant Gas Injection Rate 
The presence of solid $\mathrm{MgO}$ may have some impact on mixing power and gas dispersion. The solid $\mathrm{MgO}$ will effectively increase the liquid density. The impact on gassed and ungassed mixing power can be calculated by substituting the effective density in Equation [24].

The effect of solids on the gas hold-up has been reported to be negligible at solids concentration less than $30 \mathrm{wt} \%$ for $d_{p}=206 \mu \mathrm{m}$. Interfacial area has also been reported to be unaffected by solids concentrations of less than $4 \mathrm{wt} \%$, for $75 \mu \mathrm{m}<\mathrm{d}_{\mathrm{p}}<600 \mu \mathrm{m}^{72}$. It is expected that the presence of solid $\mathrm{MgO}$ will have little or no effect on gas dispersion below 4 wt\%.

In a typical solid-liquid system, such as found in most leaching operations, reaction rates are generally found to be nearly independant of impeller speeds. once the solid particles are completely suspended. This fact has lead to a large number of correlations for the speed which will just suspend all the solid particles $\left(N_{J S}\right)$. Zwietering developed the most successful correlation for $\mathrm{N}_{\mathrm{JS}}{ }^{73}$ :

$$
N_{J S} \quad=S v^{0.1} d^{0.2}(g \Delta \rho / \rho)^{0.45} X^{0.13} / D^{0.85}
$$

Nienow determined values of $S$ for different geometrys. For a $C / T=0.24$ and $D / T=0.48$, the value of $S$ for Rushton type turbines is about $5^{73}$.

The speed required to achieve a homogenous suspension of particles is always higher than $\mathrm{N}_{\mathrm{ss}}$; however, no good correlations exist to calculate this speed. Normally homogeneity can best be tested by performing a wash-out test, which verifies that the solids residence time is as one would expect from an ideal continuous stirred tank reactor $(\text { CSTR })^{74}$. 


\section{Chapter 4 Experimental Part I: Mixing and Gas Injection}

\subsection{Experimental Objectives}

Experiments were conducted with three major objectives:

1) to determine the un-gassed power number of the rotary gas injector,

2) to determine the relationship between gassed and un-gassed power for the rotary injector. and

3) to visualize the gas dispersion within the chlorination reactor.

\subsection{Apparatus}

The apparatus to be described in Chapter 5 was used for power measurements in $\mathrm{MgCl}_{2}$ and water. The following additional equipment were also used for testing in water:

1) a dynamometer (see Figure 14), and

2) a plexiglass model of the chlorination reactor.

\subsection{Experimental Procedure}

\subsubsection{Un-gassed Mixing Power}

The dynamometer shown in Figure 14 was used to determine the power number of the rotary gas injector. This dynamometer was designed and built at the Noranda Technology Centre for testing of impellers of about $6 \%(0.15 \mathrm{~m})$ in diameter. 
A variable speed D.C. motor was used to rotate the impeller shaft. which was directly coupled to one end of the motor. The D.C. motor was mounted on well lubricated ball bearings. The entire motor was free to rotate about its central axis. The movement of the motor was restrained by 2 pins in slots at the base of the motor. A digital tachometer was attached to the end of the motor shaft opposite the impeller shaft. as shown in Figure 14.

The dynamometer used a $0.25 \mathrm{~m}$ long lever arm to transmit the reactive torque of the impeller to a string. which was placed over a well lubricated pulley. Static weights were attached to the string to just balance the torque (the point at which the restraining pins remained centered in their slots).

The mixing power could be obtained from the following equationsis:

$$
\mathrm{P}=2 \pi \mathrm{NM}
$$

where: $\quad \mathrm{M}=\mathrm{g} \mathrm{m} \mathrm{L}$

The power number was then calculated by solving Equation [24].

An aluminum impeller shaft and a plexiglass reactor, both geometrically similar to those used in the hot chlorinator, were fabricated and used during these experiments. Actual graphite impellers were used with the aluminum shaft.

Un-gassed mixing power was also determined using the drive mechanism from the chlorination experiments. Electrical power was determined by measuring the armature voltage an $r_{i}$ current of the D.C. motor:

$$
\mathrm{P}=\mathrm{VI}
$$

The electrical power required to spin the impeller in air $\left(\mathrm{P}_{2}\right)$ at various speeds was determined after a period of 4-5 hours operation in air at 1000 R.P.M. (to allow the bearings to achieve a steady temperature). The electrical power ( $\mathrm{P})$ required to spin the impeller in water and in molten $\mathrm{MgCl}_{2}$ (containing no $\mathrm{MgO}$ ) were then determiner. 


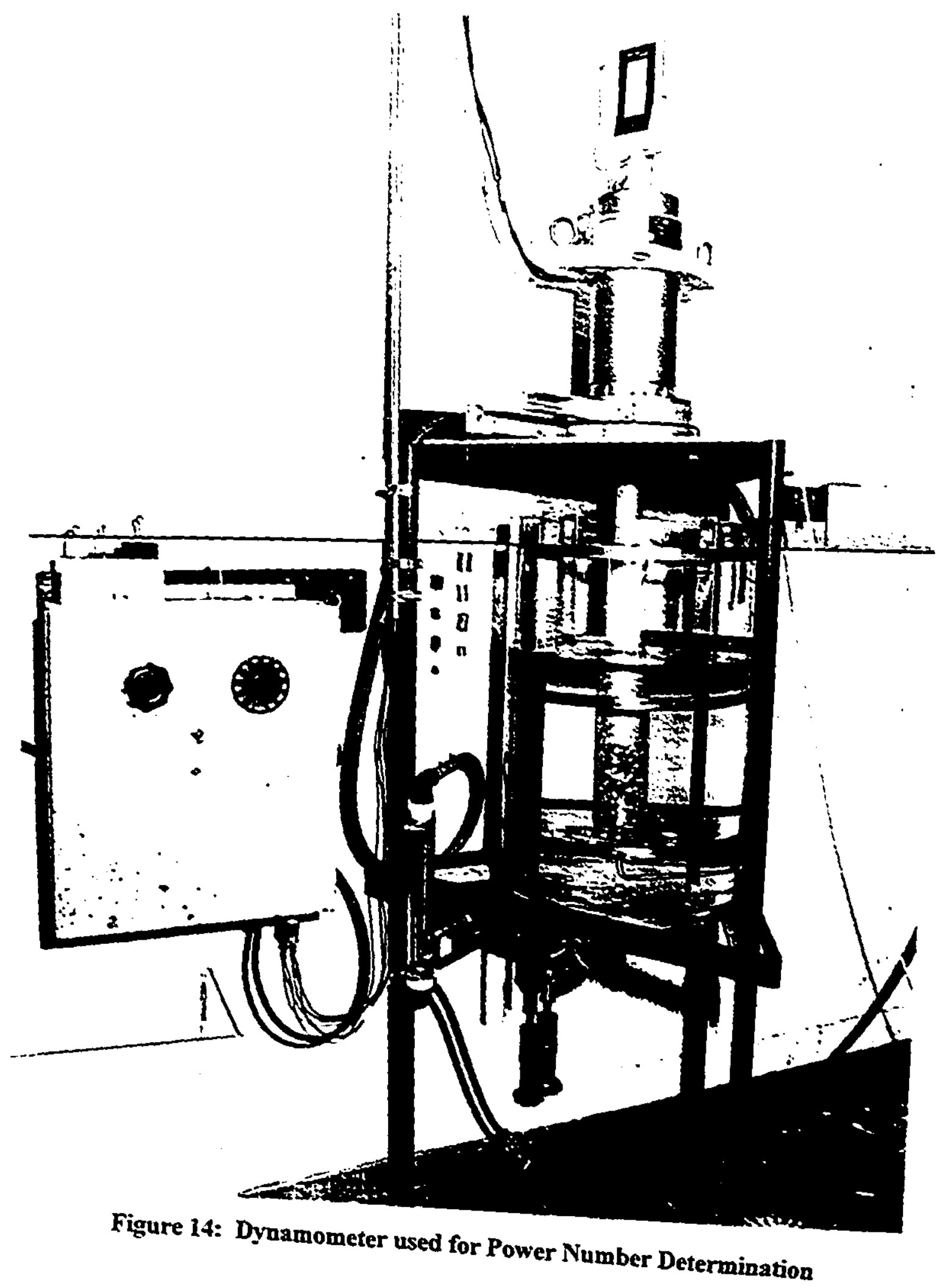


The un-gassed mixing power $\left(P_{o}\right)$ was calculated by suctracting the power in air from the total power required to spin the impeller in the liquid:

$$
\mathrm{P}_{0}=\mathrm{P}_{1}-\mathrm{P}_{2}
$$

The density of moiten $\mathrm{MgCl}_{2}$ was calculated from Equation [6] and then the power number calculated from Equation [24]. This method had been previously verified in water, by comparison with dynamometer readings for approximately $6 "(0.15 \mathrm{~m})$ diameter impellers ${ }^{76}$.

In order to avoid plugging the graphite impeller in the $\mathrm{MgCl}_{2}$, a flow of $50-100 \mathrm{~mL} / \mathrm{min}$ of nitrogen was necessary for the new impeller (this low gas flow will have introduced an error of about $1 \%$ in the estimate of the true un-gassed power). The used graphite impeller was tested without this small gas flow, since the impeller was near the end of its usefui life.

\subsubsection{Gassed Mixing Power}

Chlorine and carbon monoxide gases were injectcd into the chlorinator in a $1 / 1$ ratio and a variety of flow rates $\left(0.5-2.25 \mathrm{~L} / \mathrm{min}\right.$ each). The molten $\mathrm{MgCl}_{2}$ had previously been chlorinated and thus contained no $\mathrm{MgO}$ to consume the gases, or interfere with density calculations.

The gassed mixing power was measured for the graphite impeller at speeds of $600-1000$ R.P.M. in molten $\mathrm{MgCl}_{2}$, using the same electrical method described above. The ratio of the gassed to un-gassed power was then calculated for each impeller speed and gas injection rate. 


\subsubsection{Visualization of Gas Dispersion}

It was not possible to observe the gas dispersion within the molten $\mathrm{MgCl}_{2}$. A plexiglass water model was therefore used to observe the degree of gas dispersion (as discussed in Chapter 3 and shown in Figure 12) at the gas injection rates and impeller speeds to be used during the hot testing.

The actual gas volume injected into the chlorinator is 4 times the gas volume at $0^{\circ} \mathrm{C}$. due to the relatively high $\left(820^{\circ} \mathrm{C}\right)$ temperatures in the reactor. For the flow visualization, it was assumed that the same actual (expanded) gas injection rate should used. Gas volumes between 8 and $24 \mathrm{~L} / \mathrm{min}$ at $21^{\circ} \mathrm{C}$ were used (equivalent to $2-6 \mathrm{~L} / \mathrm{min}$ at S.T.P. of a mixture of $\mathrm{Cl}_{2}$ and $\mathrm{CO}$ in the actual chlorinator at $820^{\circ} \mathrm{C}$ ). The effect of the difference in pressure head. due to the difference in densities of $\mathrm{MgCl}_{2}$ and water, on the gas volume was ignored, since it represents less than $1 \%$ of 1 atmosphere. 


\section{Chapter 5 Experimental Part II: Reaction Kinetics}

\subsection{Experimental Objectives}

Experiments were conducted with three major objectives:

1) to determine if magnesite $\left(\mathrm{MgCO}_{3}\right)$ could be chlorinated in a stirred reactor using chlorine $\left(\mathrm{Cl}_{2}\right)$ and carbon monoxide $(\mathrm{CO})$ gas, under conditions which could reproduced industrially,

2) to determine the effect of the various process parameters on the apparent reaction kinetics, and

3) to infer the probable rate controlling step from the experimental results.

\subsection{Apparatus}

A general schematic of the apparatus used in these experiments is given in Figure 15. The apparatus consisted of 4 main components:

1) furnace (see Figure 16),

2) reactor (see Figures 17 and $18^{77}$ ),

3) rotary gas injector (see Figures 17-1977), and

4) controls (see Figure 20).

A comprehensive list of names and addresses of suppliers is provided in Appendix A. 


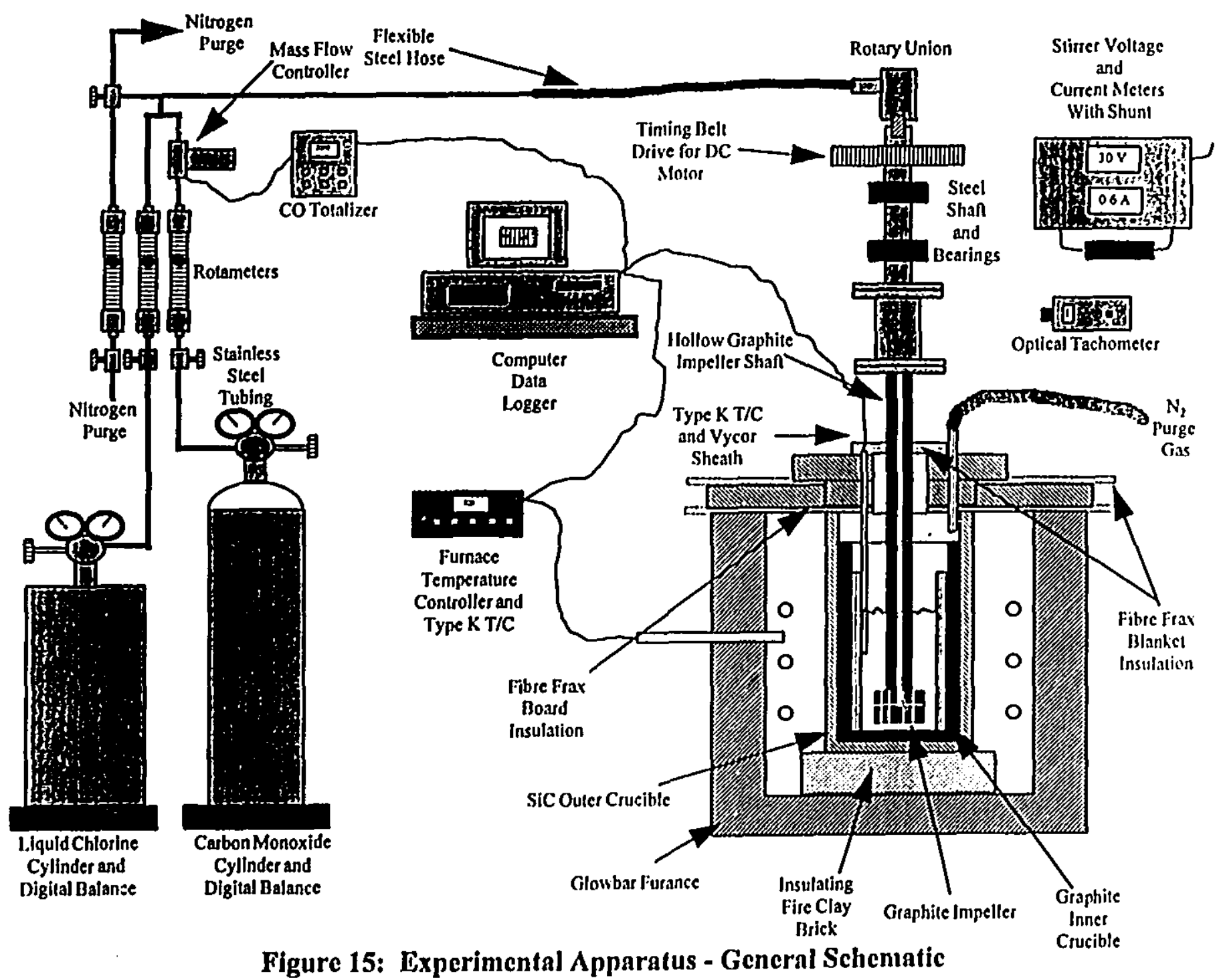




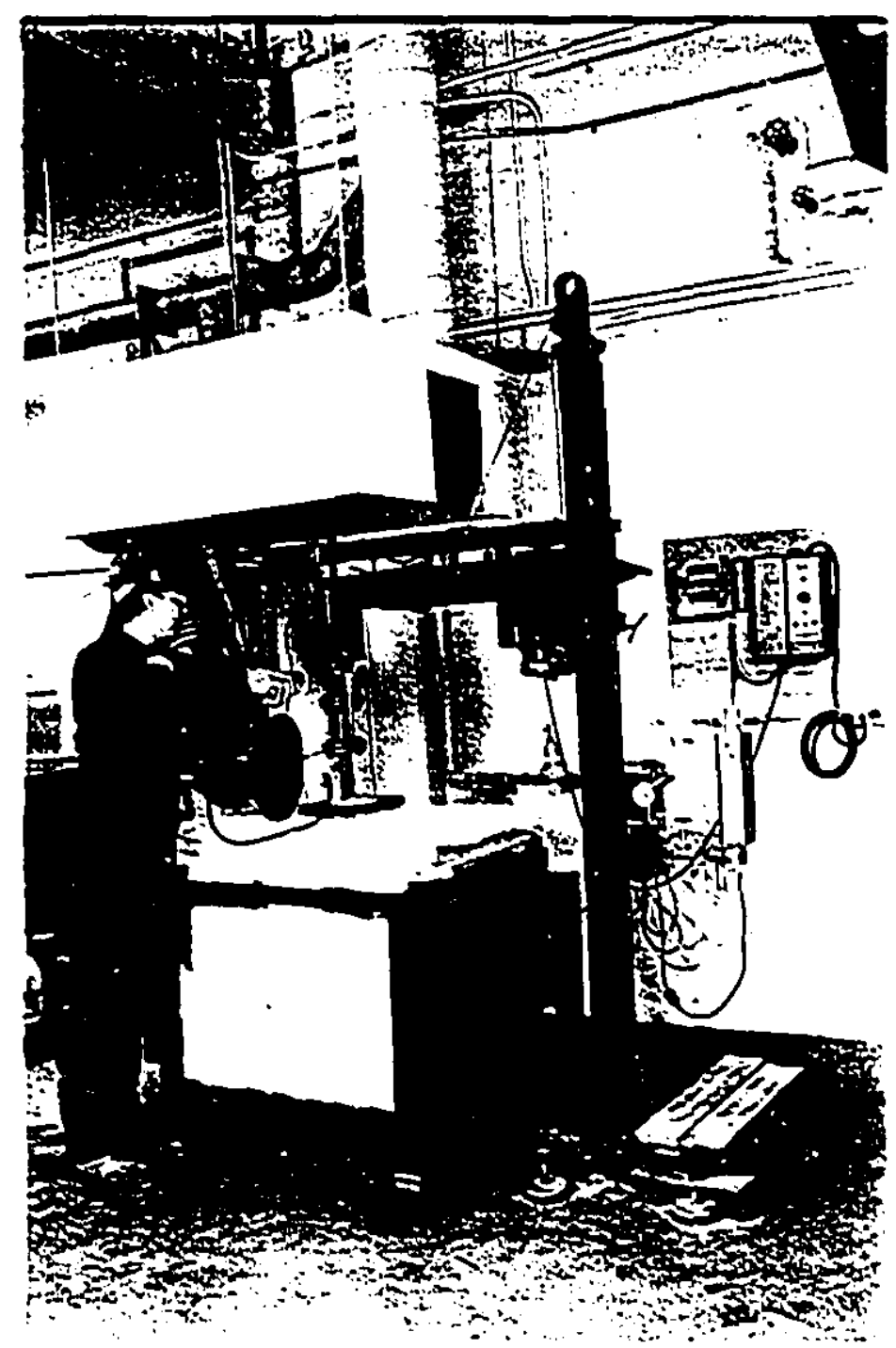

Figure 16: 40 kVA "Glowbar" Furnace 


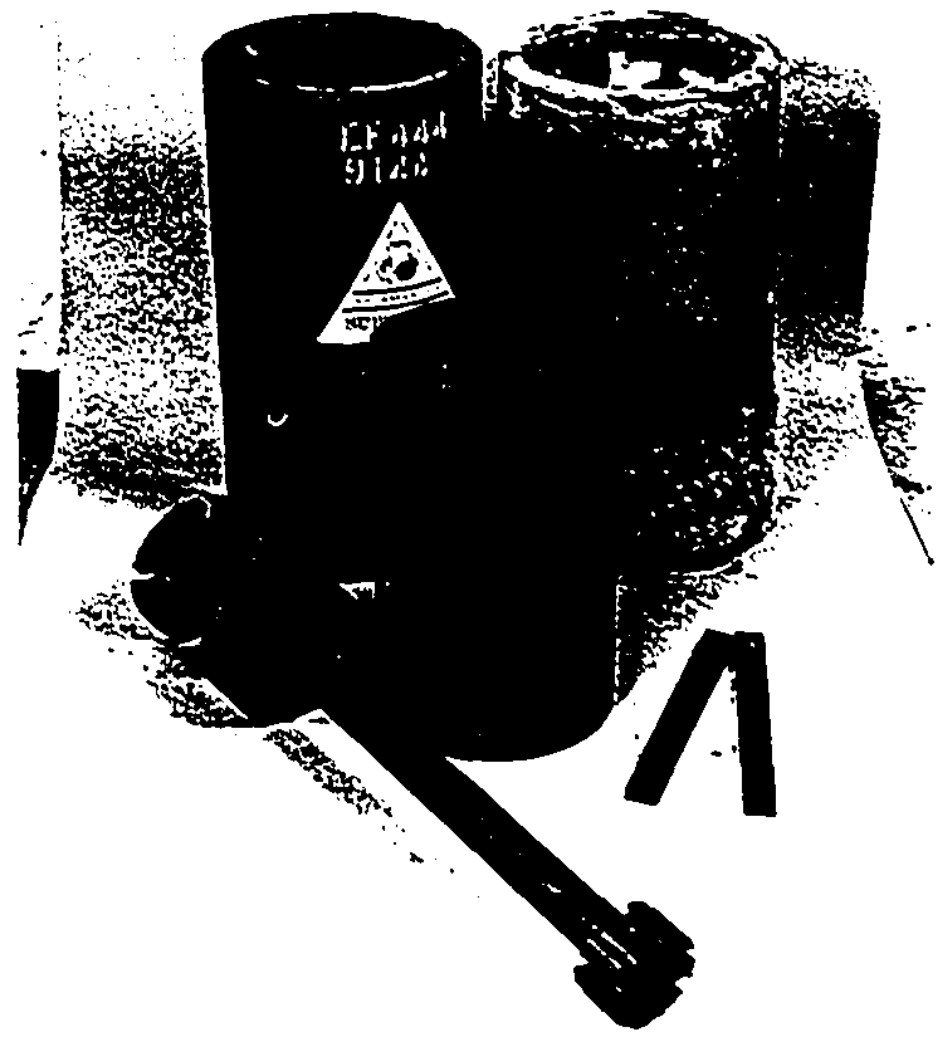

Figure 17: New and Used Reactor Crucibles, with New Gas Injector 


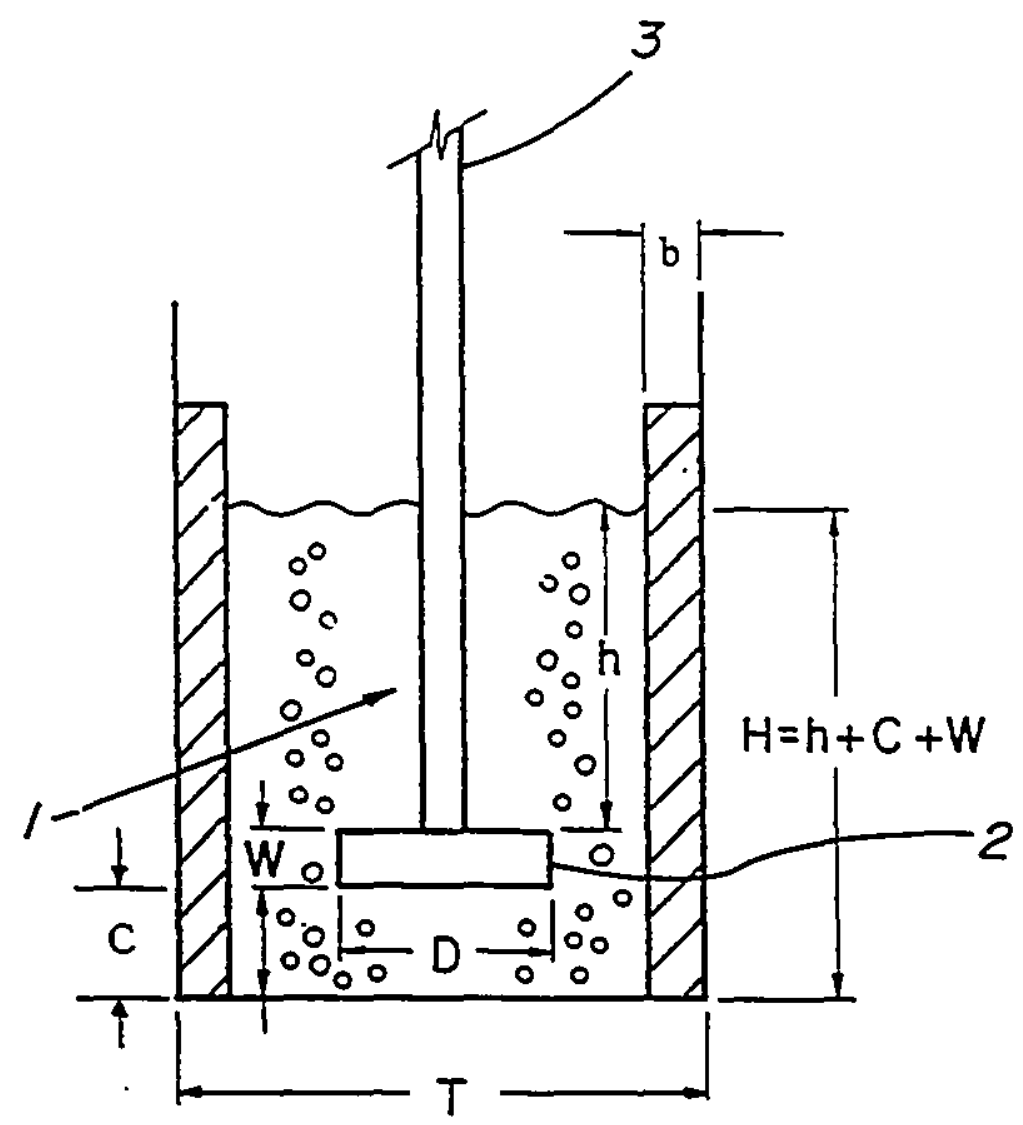

Figure 18: Graphite Reactor and Impeller - General Schematic

The rotary gas injector (1), with impeller (2) and shaft (3), is located height (C), above the bottom of the reactor. The impeller has width $(\mathrm{W})$ and is height $(\mathrm{h})$, bellow the surface of the $\mathrm{MgCl}_{2}$ bath. Four baffles of width (b), are located in the reactor, of width (T). 

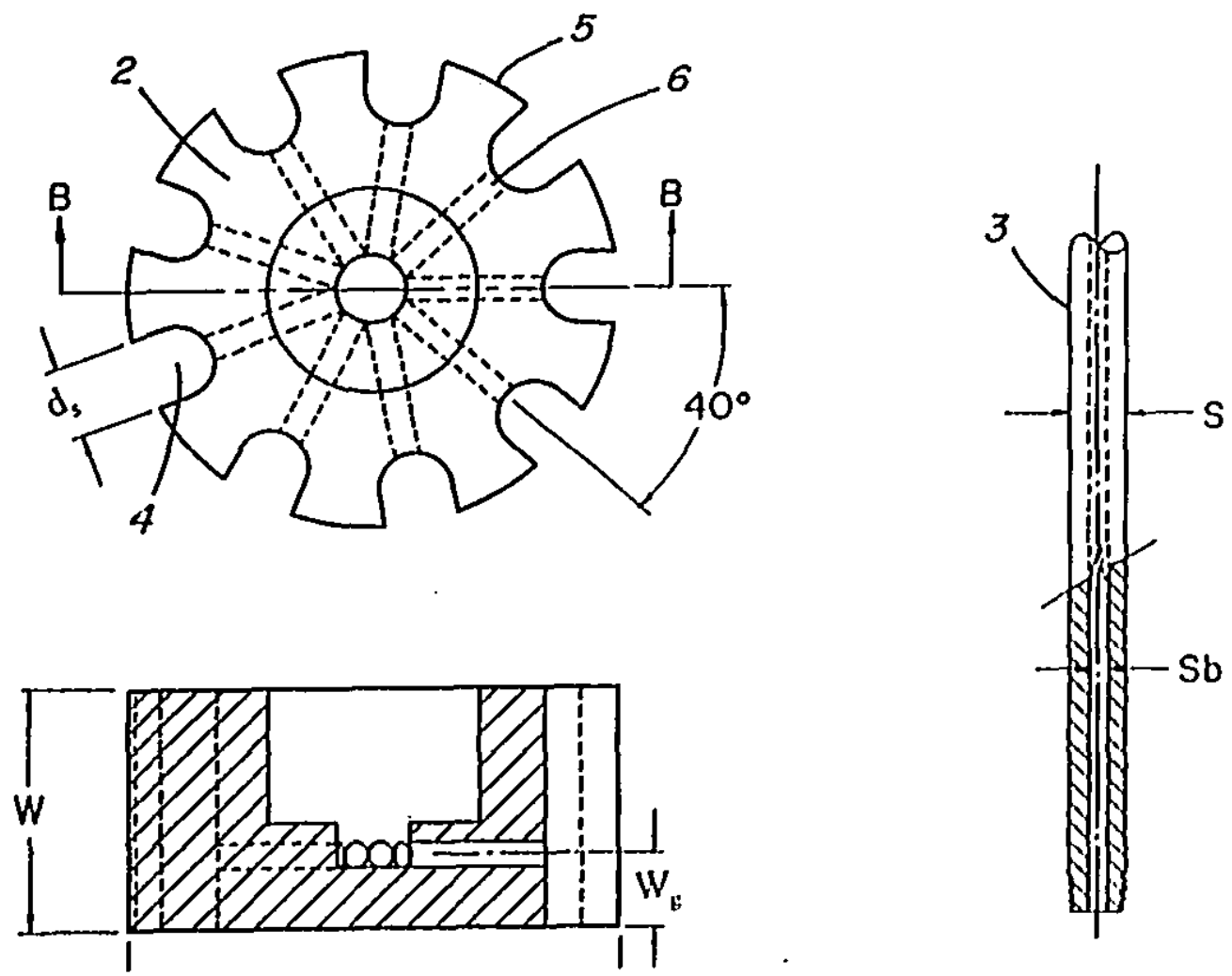

Figure 19: Schematic of Graphite Impeller and Shaft

The impeller (2) is shown with slots (4), of width $\left(d_{s}\right)$. The material left between these slots, form the blades (5) of the impeller. Gas is injected through holes (6), from a height $\left(W_{\mathrm{g}}\right)$, above the bottom of each slot. The impeller shaft (3) has width (S) and bore diameter $\left(S_{b}\right)$. 


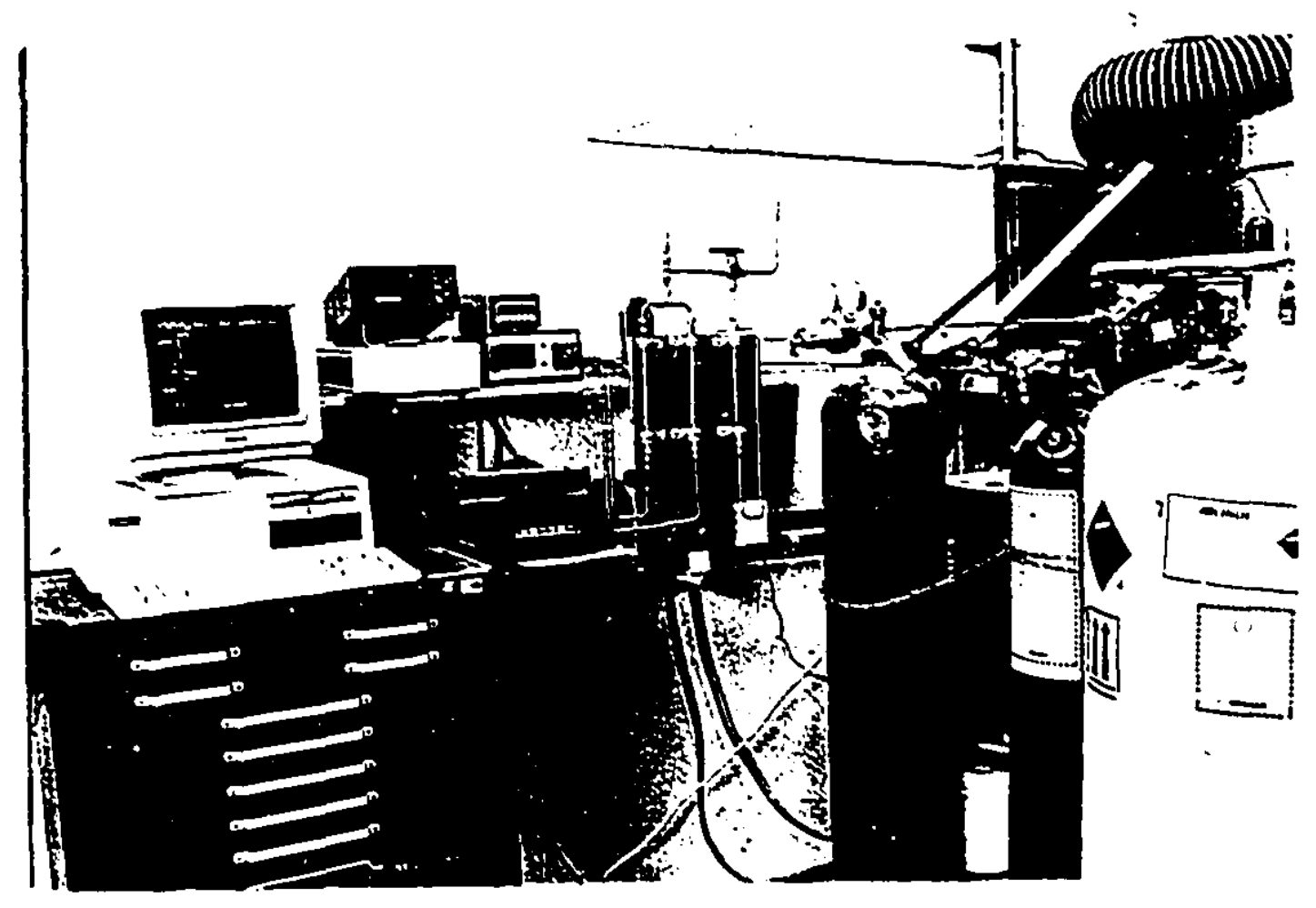

Figure 20: Control and Measuring Devices including: Data Logger, Mass Flow Controller, CO Totalizer. Gas Rotameters, Cylinders, Piping and Control Valves, Digital Scale Indicator, and Furnace Controller. 


\subsubsection{Furnace}

A 3-phasc, $40 \mathrm{kVA}$ (200 A, 208V), resistance heated. "glowbar." furnace was used in these experiments. This furnace was controlled via a type $K$ thermocouple located in the heating zone of the furnace, and an Omega CN9111 A. on/off controller. Carborundum. Fibre Frax Duraboard insulation (2" thick), was used to construct a crucible lid, and furnace cover. Fibre Frax Durablanket (1" thick), was used to make the furnace nearly gas tight. Primary ventilation was provided by an $8^{*}$ wall supported ventilation duct. while secondary ventilation was provided by a hood located above the furnace. All gases were scrubbed via a commercial caustic scrubber. attached to the building ventilation system. Detail can be seen in Figure 16.

\subsubsection{Reactor}

A silir.un carbide, Morganite EF 444, Salamander crucible (O.H. - 476 mm, I.H. - 451 $\mathrm{mm}$, O.D. - $254 \mathrm{~mm}$, I.D. - $216 \mathrm{~mm}$ ) was used to protect a graphite (Speer-890 S) crucible (O.H. - 13", I.H. - 12", O.D. - 8", I.D. - 6.250") from oxidation. The inner crucible was equipped with four graphite (UCAR-ATJ) baffles, which were 10" high. 0.490 " thick and 1.000 " wide. These baffles were counter sunk 0.375 ", into 0.500 " wide slots in the walls of the crucible, at $90^{\circ}$ intervals. The baffles were held in place using graphite (UCAR C-34) cement. The various parts, new and used can be seen in Figure 17. A schematic of the inner crucible and rotary gas injector are included as Figures 18 and $19^{77}$. 


\subsubsection{Rotary Gas Injector}

Gas was injected into the vessel after passing through a Deublin rotary union (Model \#1102070 081. 1/4”. N.P.T.. R.H.T.). From the rotary union. the gas flowed into a hollow steel shaft. $1.000^{\prime \prime}$ in diameter, with a $0.250^{\prime \prime}$ central bore (see schematic Figure 15). The steel shaft was held extremely straight. by using two sets of self centering pillow block bearings (Seal Master NP16C), spaced about 8.5 " apart. The steel shaft was driven using 2" wide toothed gears and timing belts (to prevent slip and insure consistent power transmission). A 1/2 horse power, direct current motor (Balder Industrial, T.E.F.C., 180V, 1.7A, 1150 R.P.M.) provided the motive power. A 2:1 gear ratio (6" and 3“) was used, allowing for a maximum impeller speed of 2300 revolutions per minute. The drive mechanism was built onto a stand, which allowed for the impeller height to be raised or lowered over several feet.

A 24" long graphite (Speer-890 S) shaft, 1.500" in diameter, with a threaded bottom (I" by 8 T.P.I.) and a 0.250 " diameter bore, was joined to the steel shaft, via a complex connector (shown in Figure 17). The connection was made gas tight by the use of $O$-ring seals and a chiorinated grease. Details of this coupling will not be made available, since these are the property of the Societe des Technologies de L aluminum (S.T.A.S.) Ltd., as part of the commercial GIFS aluminum fluxing system.

A graphite (UCAR-ATJ) impeller, 3.000" in diameter and 1.500" thick, was attached to the bottom of the graphite shaft, via 1/2" of thread (8 T.P.I.). Gas was released via 9 holes of 0.125 " diameter, located 0.5 " from the impeller bottom, in 9 - U shaped slots. These slots had a width and depth of 0.454 ".

Speer $\$ 90 \mathrm{~S}$ graphite, is an extruded grade of graphite, with above average mechanical properties (high flexural strength of 3200 P.S.I. ${ }^{78}$ ), and is an inexpensive choice for large 
mechanical parts such as mixer shafts. UCAR ATJ graphite, is a ver: high quality. isostatically molded graphite, with superior mechanical properties (avcrage flexural strength of over +250 P.S.I.) and excellent natura' resistance to oxidation (low porosity) ${ }^{7 \%}$.

Quality of graphite is determined by source of carbon (particle size, ash and impurity content), forming technique (extrudied. molded, or isostatically molded) and the number of times they are impregnated by pitch and re-graphitized (low porosity and high apparent density). The most expensive grades. such as ATJ. are isostatically molded of fine grained graphite $(0.15 \mathrm{~mm})$, with very low ash content $(0.16 \%)$, and multiply impregnated with pitch and re-graphitized (about 3 times), resulting in high bulk density (1.76 g/cm vs. the theoretical for graphite of $2.25 \mathrm{~g} / \mathrm{cm}^{3}$ or for amorphous carbon of $1 . S$ $2.1 \mathrm{~g} / \mathrm{cm}^{3}{ }^{80}$ ) and low Darcy's permeability $(0.002)^{79}$. The least expensive grades are extruded and either non-impregnated or singly impregnated with pitch.

Table 7 summarizes the value and dimensional ratios of the experimental apparatus.

Table 7: Dimensions and Dimensionless Ratios for Experimental Apparatus

\begin{tabular}{ccccc}
\hline Dimension & Symbol & $\begin{array}{c}\text { Value } \\
\text { (inches) }\end{array}$ & $\begin{array}{c}\text { Value } \\
\text { (mm) }\end{array}$ & $\begin{array}{c}\text { Dimensionless } \\
\text { Ratio } \\
\text { (Dimension/T) }\end{array}$ \\
\hline reactor diameter & $\mathrm{T}$ & 6.25 & 159 & 1 \\
total liquid depth & $\mathrm{H}$ & 6.5 & 165 & 1.04. \\
impeller diameter & $\mathrm{D}$ & 3.0 & 76 & 0.46 \\
impeller thickness & $\mathrm{W}$ & 1.5 & 38 & 0.23 \\
impeller height from bottom & $\mathrm{C}$ & 1.5 & 38 & 0.23 \\
$\begin{array}{c}\text { baffle width } \\
\text { liquid height above impeller }\end{array}$ & $\mathrm{b}$ & 0.625 & 16 & 0.1 \\
impeller shaft diameter & $\mathrm{h}$ & 3.5 & 89 & 0.56 \\
impeller shaft bore diameter & $\mathrm{S}$ & 1.5 & $3 \mathrm{~S}$ & 0.23 \\
height of gas holes above & $\mathrm{S}_{\mathrm{b}}$ & 0.25 & 6 & 0.04 \\
impeller bottom & $\mathrm{W}_{\mathrm{g}}$ & 0.5 & 13 & 0.08 \\
width of the slots in impeller & $\mathrm{d}_{\mathrm{s}}$ & 0.454 & 11.5 & 0.073 \\
\hline
\end{tabular}




\subsubsection{Controls}

Impeller speed was determined using a Shimpo optical tachometer. Model DT $205 \mathrm{~B}$. using a reflector mounted on the side of the sted shaft. This method had an accuracy of about 1 revolution per minute. Impeller speed was controlled using an Emerson Industrial Controls. Focus 2. Model PN2450-8000, direct current speed controller. Mixing power was determined by monitoring the armature voltage and current, using two Meter Master. Model RP-35V meters. Current was converted to a voltage reading. by using a $10 \mathrm{~A} 100 \mathrm{mV}$ shunt.

Temperature was monitored using type $K$ thermocouples manufactured by R.D.C.. in 1/8" diameter. by 24" long. stainless steel sheaths. These thermocouples were used for both furnace control and monitoring the reactor temperature. Vycor glass tubes (by Dow Corning), sealed at one end. with $7 \mathrm{~mm}$ O.D. and $1 \mathrm{~mm}$ wall thickness, were used to protect the stainless steel thermocouple sheaths from the corrosive environment in the reactor.

Gas flow was determined using Gilmont rotameters with glass balls, as follows: carbon monoxide (\#2 - 23335), chlorine ( $\# 2$ - R686 or \#3 -61664), nitrogen ( $\# 3$ - 31627). Flow meters were calibrated using a GCA Precision Scientific, wet gas flow meter and using the Gilmont flow rate analysis software. Model GF-4000 Ver. 1.0. The calculated flow rates were found to match those of the wet gas flow meter to the limit of accuracy of the rotameters (1/2 of 1 division).

Carbon monoxide flow was regulated using a Matheson mass flow controller, Model 8270. This unit was designed for $0-5 \mathrm{~L} / \mathrm{min}$. with a $0.01 \mathrm{~L} / \mathrm{min}$. resolution and was equipped with a $0-5 \mathrm{~V}$ output. This unit was used to regulate the flow at a value 
determined from the (iilmoni rotameter. Totalized CO flow was monitored using an Omega Model DPFoo ratemeterítotalizer.

Liquid chlorine and nitrogen, and compressed carbon monoxide gas cylinders, were piped through $1 / 4$ " stainless steel tubing. Needle valves on the gas regulators were used to control the flow of nitrogen and chlorine. The liquid chlorine cylinder sat upon a Toledo Model 8140 balance, with a resolution of $0.05 \mathrm{lb}$. $(0.02 \mathrm{~kg})$. The carbon monoxide cylinder was weighed with a Howe Richardson Model L.P. 544/H.R.50 floor scale, with a maximum resolution of $0.1 \mathrm{lb} .(0.05 \mathrm{~kg})$.

A Nova Tector. Tox-tector, portable CO meter was used to monitor for unsafe levels of carbon monoxide in the area of the experiments.

Temperature and carbon monoxide flow were continuously monitored using a Cole Parmer, 14 channel data logger (Model Mac 14). Data were displayed and stored on an I.B.M. XT clone (Mutli-Tech 700 plus), with a 30 megabyte hard drive.

Many of the controls described above. can be seen in Figure 20.

\subsection{Reagents}

For the results of these experiments to be valid at any scale, it was necessary to carefully choose the quality of the reagents. A conscious decision was therefore made to use reagents of less than the maximum possible "laboratory" purity.

Natural magnesite $\left(\mathrm{MgCO}_{3}\right)$ from the Baymag deposit ${ }^{37}$ was chosen for use in these experiments. About $10 \mathrm{~kg}$ of magnesite ore $(-2 *$ or $-50 \mathrm{~mm})$ from Lot $¥ 225062$ were 
used. It was necessary to prepare this material for use, by comminution. The ore was first crushed with a jaiv and then a roll crusher. The crushed material (mostly $-0.25 \%$ or -6 $\mathrm{mm}$ ) was then pulverized using a disk pulverizer and subsequently screened (Tyler screens: $50,70,100,140,200$, and 270). The oversized material (>50 mesh) was recrushed and re-screened. Figure 21 , is a photo of the as received magnesite ore and the 106-150 $\mu \mathrm{m}$ size fraction. Assays of the various size fractions. obtained by indirectly coupled plasma (I.C.P.) spectrography, are given in Table 8.

An initial bath of anhydrous magnesium chloride $\left(\mathrm{MgCl}_{2}\right)$ had to be created, into which the magnesite could be fed. Aldrich, anhydrous magnesium chloride (formula weight 95.22, melting point $714^{\circ} \mathrm{C}$. S.G. 2.320, particle size $<20 \mu \mathrm{m}$ ), from lot number $10204 \mathrm{AF}$ was used. This material was guaranteed to be less than $5 \%$ water, but was found to be less than $1.0 \%$ water (by Karl Fischer titration). Assays for this material are given in Table 9. All assays accept $\mathrm{H}_{2} \mathrm{O}$ and $\mathrm{MgO}$ are by I.C.P.. Magnesium oxide assays are by back titration (see experimental procedures below).

High purity liquid chlorine (H.P. grade produced by Matheson) and compressed carbon monoxide (C.P. grade by Praxair) both $99.5 \%$ pure were used. Commercial liquid nitrogen (by Praxair) was used (equivalent to extra dry nitrogen).

\subsection{Experimental Procedures}

The graphite reactor was charged with sufficient solid magnesium chloride (about $5 \mathrm{~kg}$ ) to fill it to a depth of 6.5-7.0" $(16.5-18 \mathrm{~cm})$ when molten. A nitrogen plrge of $3 \mathrm{~L} / \mathrm{min}$. was applied to the freeboard of the reactor (all flows are at standard temperature and pressure, $0^{\circ} \mathrm{C}$ and 1 atmosphere) and the furnace was heated to about $800^{\circ} \mathrm{C}$. When new Aldrich $\mathrm{MgCl}_{2}$ was used, a pre-chlorination was done at this point to remove traces of $\mathrm{MgO}$ from sources other than $\mathrm{MgCO}_{3}$. 


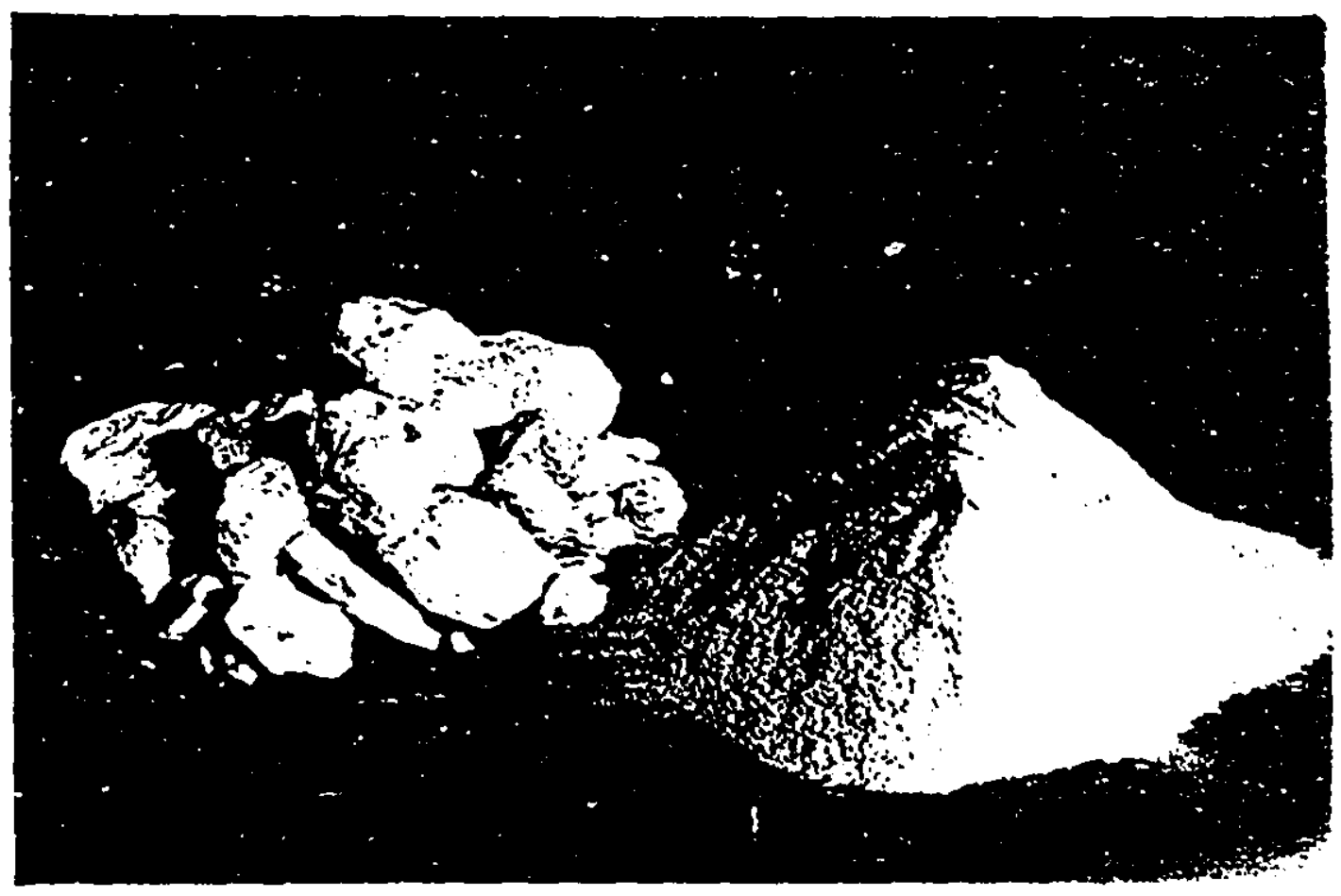

Figure 21: Magnesite Ore as Received and 106-150 $\mu \mathrm{m}$ Crushed Fraction 
Table 8: Baymag Magnesite $\left(\mathrm{MgCO}_{3}\right)$ - Head Samples

\begin{tabular}{|c|c|c|c|c|c|c|c|c|c|c|c|c|c|}
\hline $\begin{array}{c}\text { Size } \\
(\mu \mathrm{m})\end{array}$ & $\begin{array}{l}\mathrm{Ca} \\
(\%)\end{array}$ & $\begin{array}{c}\mathrm{Na} \\
(\mathrm{ppm})\end{array}$ & $\begin{array}{c}\mathrm{K} \\
(\mathrm{ppm})\end{array}$ & $\begin{array}{c}\mathrm{Si} \\
(\mathrm{ppm})\end{array}$ & $\begin{array}{c}\mathrm{Al} \\
(\mathrm{ppm})\end{array}$ & $\begin{array}{c}\text { B } \\
(\mathrm{ppm})\end{array}$ & $\begin{array}{c}\mathrm{Cu} \\
(\mathrm{ppm})\end{array}$ & $\begin{array}{l}\text { Fe } \\
(\%)\end{array}$ & $\begin{array}{c}\mathrm{Ni} \\
\text { (ppm) }\end{array}$ & $\begin{array}{c}\mathrm{Cd} \\
(\mathrm{ppm})\end{array}$ & $\begin{array}{c}\mathrm{Pb} \\
\text { (ppm) }\end{array}$ & $\begin{array}{c}\mathrm{Mn} \\
(\mathrm{ppm})\end{array}$ & $\begin{array}{c}\mathrm{Sb} \\
(\mathrm{ppm})\end{array}$ \\
\hline$<53$ & 0.66 & $97: 5$ & 109 & 747 & 353 & 28 & 1600 & 0.30 & 30 & $N / A$ & 237 & 118 & 85 \\
\hline $53-75$ & 0.68 & N/A & N/A & 438 & 166 & 74 & 118 & 0.20 & 2 & $<0.5$ & 25 & 120 & 59 \\
\hline $53-75$ & 0.50 & 636 & $<100$ & 460 & 252 & 29 & 954 & 0.23 & 17 & $N / A$ & 150 & 96 & 73 \\
\hline $75-106$ & 0.49 & 557 & $<100$ & 152 & 187 & 22 & 706 & 0.21 & 14 & $N / A$ & 153 & 95 & 62 \\
\hline $106-150$ & 0.46 & 464 & $<100$ & 105 & 151 & 18 & 485 & 0.19 & 13 & $N / A$ & 113 & 91 & 56 \\
\hline $150-212$ & 0.46 & 291 & $<100$ & 104 & 84 & 17 & 141 & 0.15 & 5 & $N / A$ & 77 & 82 & 55 \\
\hline $212-300$ & 0.49 & 247 & $<100$ & 83 & 82 & 21 & 67 & 0.12 & 6 & $\mathrm{~N} / \mathrm{A}$ & 6 & 77 & 56 \\
\hline
\end{tabular}

'Table 9: Aldrich Anhydrous Magnesium Chloride Assays

\begin{tabular}{cccccccc}
\hline Samplc & $\begin{array}{c}\mathrm{MgO} \\
(\%)\end{array}$ & $\begin{array}{c}\mathrm{H}_{2} \mathrm{O} \\
(\%)\end{array}$ & $\begin{array}{c}\mathrm{Ca} \\
(\mathrm{ppm})\end{array}$ & $\begin{array}{c}\mathrm{Na} \\
(\mathrm{ppm})\end{array}$ & $\begin{array}{c}\mathrm{K} \\
(\mathrm{ppm})\end{array}$ & $\begin{array}{c}\mathrm{Li} \\
(\mathrm{ppm})\end{array}$ & $\begin{array}{c}\mathrm{Al} \\
(\mathrm{ppm})\end{array}$ \\
\hline 1 & 0.14 & $0.63 / 0.66$ & $\mathrm{~N} / \mathrm{A}$ & $\mathrm{N} / \mathrm{A}$ & $\mathrm{N} / \mathrm{A}$ & $\mathrm{N} / \mathrm{A}$ & $\mathrm{N} / \mathrm{A}$ \\
2 & 0.04 & $1.05 / 0.94$ & $\mathrm{~N} / \mathrm{A}$ & $\mathrm{N} / \mathrm{A}$ & $\mathrm{N} / \mathrm{A}$ & $\mathrm{N} / \mathrm{A}$ & $\mathrm{N} / \mathrm{A}$ \\
3 & 0.17 & $1.07 / 1.05$ & $0.44 / 0.39$ & $3.6 / 3.8$ & $30 / 39$ & $0.1 / 0.1$ & $4.1 / 4.1$ \\
\hline
\end{tabular}


Once the $\mathrm{MgCl}_{2}$ charge was molten, the depth of the molten bath was measured by inserting a glass rod into the reactor and then measuring the length of material frozen on the rod. This was normally repeated several times to obtain a good average. If the depth was too high, a quartz ladle was used to remove the excess material. If the depth was too low, additional solid $\mathrm{MgCl}_{2}$ was added.

When the correct depth was obtained, 300-600 $\mathrm{g}_{\text {of }} \mathrm{MgCO}_{3}$ was added, to give a $\mathrm{MgO}$ solids weight fraction of 2.5-5\%. Surface moisture was removed from the $\mathrm{MgCO}_{3}$ prior to use, by heating at $200{ }^{\circ} \mathrm{C}$ for 1 hour. This was done to prevent any moisture from creating $\mathrm{MgO}$, which might react differently from the $\mathrm{MgO}$ produced by the decomposition of the $\mathrm{MgCO}_{3}$.

Once the reactor had stopped fuming ( $\mathrm{CO}_{2}$ evolution was complete), the reactor was heated to about $10^{\circ} \mathrm{C}$ less than the expected operating temperature and the rotary gas injector was lowered to the proper elevation (set by the location of a retaining ring). Nitrogen was applied to the impeller, prior to lowering it into the reactor, in order to prevent it from becoming plugged with solidified $\mathrm{MgCl}_{2}$. The depth was measured and recorded both before and after immersion of the impeller.

The gas injector was then spun to the appropriate speed and after about 10 minutes, a samp's of $\mathrm{MgCl}_{2}$ of about $30-50 \mathrm{~g}$ was taken using a pipette bulb and a $7 \mathrm{~mm}$ diameter Vycor tube (with a $1 \mathrm{~mm}$ wall thickness). About 3 separate tubes were used in succession. A second sample was taken about 10 minutes later. These samples were divided into 2 equal parts, one part was saved for labcratory analysis, the other was subjected to a simple bench test to determine the $\mathrm{MgO}$ content. This sampling procedure is demonstrated in Figure 22. In using this technique, it was assumed that the agitation provided by the mixer was sufficient that the $\mathrm{MgO}$ was homogeneously distributed throughout the molten bath of $\mathrm{MgCl}_{2}$. This assumption is discussed in Chapter 7 and in Appendix B. 


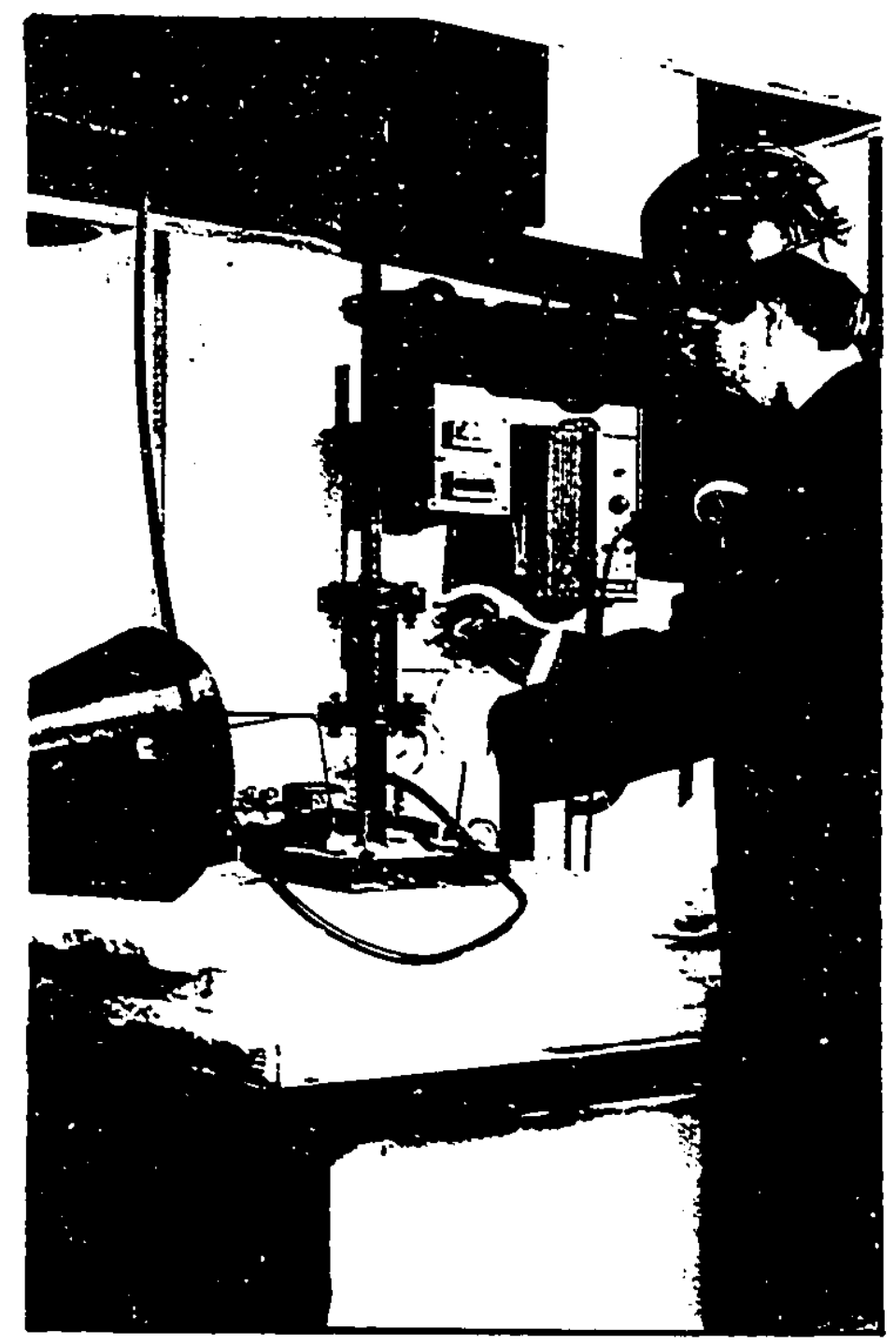

Figure 22: Melt Sampling Procedure 
When the starting amount of $\mathrm{MgO}$ had been verified and the reactor temperature had stabilized. the chlorine and carbon monoxide were turned on and the nitrogen from the impeller was switched back to the reactor free board. This was taken to be time zero for the experiment.

Flow rates were adjusted about every 5-10 minutes to maintain constant values. Normally the $\mathrm{CO}$ flow rate was perfectly stable, due to the use of a mass fiow controller. At exactly 15 minute intervals, additional melt samples were taken for later laboratory analysis for $\mathrm{MgO}$ and manual recordings were taken of all flows, reactor temperature. impeller speed, voltage, and current. At orie hour intervals, double samples were taken and one of these samples was used to perform additional $\mathrm{MgO}$ bench tests, to monitor the progress of the experiment.

The experiment was terminated 1 hour after a sample with less than $1 \% \mathrm{MgO}$ was taken (nomally an end point of about $0.1 \% \mathrm{MgO}$ ). Just prior to the end of the experiment the depth of the gas-liquid mixture in the reactor was measured. This was done using the same glass rod described earlier. This procedure was difficult due to the small size of the reactor and the presence of the rotating impeller (duplicate readings were therefore not performed). At the end of the experiment, another set of depth measurements were taken using a glass rod, both with the impeller immersed and not (difference of about $10 \mathrm{~mm}$ ).

Just prior to ending the experiment, the power required to rotate the impeller was determined by measuring the armature voltage and current. The power required to spin the same assembly in air was then taken and the difference was assumed to be the amount dissipated in the bath (see Chapter 4 for details).

Initial and final weights of the chlorine and carbon monoxide cylinders were taken as a cross check against the recorded flow rates. This proved of little value for the carbon monoxide, since its low molecular weight resulted in very little mass being used. 
After the completion of an experiment, the $\mathrm{MgCl}_{2}$ in the reactor was allowed to solidify under nitrogen. Normally the $\mathrm{MgCl}_{2}$ was re-used for subsequent experiments. by simply re-meiting and doping with $\mathrm{MgCO}_{3}$. The $\mathrm{MgCl}_{2}$ was changed as required (such as when a new reactor was used). Air oxidation of the top of the reactor required it to be changed once. The impeller was also changed twice (one broken and one plugged).

\subsubsection{Analytical Procedures}

The main analytical procedures used in these experiments were for the determination of MgO. A simple bench test was developed for control of the experiments and a back titration procedure was used for precise analytical determinations accurate to less than $0.1 \% \mathrm{MgO}$.

The bench test consisted of taking a sample of about $25 \mathrm{~g}$ of the melt from the reactor using the technique demonstrated in Figure 21. The material frozen inside the Vycor tube, was pushed out using a steel rod. This material was placed on a watch glass and weighed on a Sartorius model A200S analytic balance, accurate to $0.0001 \mathrm{~g}$. The material was washed into a $1 \mathrm{~L}$ beaker filled with approximately $0.5 \mathrm{~L}$ of water. A magnetic stirring bar was added and the beaker was mixed until the $\mathrm{MgCl}_{2}$ had dissolved. The insoluble $\mathrm{MgO}$, was filtered through a pre-weighed filter paper, by vacuum filtration. The filter paper and $\mathrm{MgO}$ sample were heated for about 10 minutes at $150^{\circ} \mathrm{C}$ and then weighed. The mass of the $\mathrm{MgO}$ was taken by difference and the percent $\mathrm{MgO}$ was calculated as the ratio of the $\mathrm{MgO}$ mass, to mass of the original melt sample.

In determining the results of the experiments, melt samples taken by the same technique as described above, were analyzed by a back titration method. In this method, $3 \mathrm{~g}$ of melt were dissolved in water and $10 \mathrm{~mL}$ of $1 \mathrm{~N} \mathrm{HCl}$ acid were added to dissolve the $\mathrm{MgO}$. The 
residual acid was titrated using $0.5 \mathrm{~N} \mathrm{NaOH}$. The end point of this back titration was determined as being $\mathrm{pH} 7+/-0.5$, using a $\mathrm{pH}$ meter standardized between $\mathrm{pH} 4.0$ and $8.0^{\mathrm{81}}$.

All minor elements were analyzed by digestion in acid. with analysis done by I.C.P.. 


\section{Chapter $6 \quad$ Results Part I: Mixing and Gas Injection}

\subsection{Un-gassed Mixing Power}

Un-gassed mixing power was determined using a dynamometer and an electrical method for water and using the electrical method for $\mathrm{MgCl}_{2}$. These data are summarized in Figure 23.

In Figure 23 the calculated power numbers $\left(N_{p}\right)$ are plotted against R.P.M.. Normally, the impeller Reynolds number $\left(\mathrm{N}_{\mathrm{Re}}\right)$ is used as the $\mathrm{X}$-axis for a plot such as Figure 23. In order to calculate the impeller Reynolds number in $\mathrm{MgCl}_{2}$, it is necessary to know both the density and viscosity of $\mathrm{MgCl}_{2}$ at the experimental temperature. The available density and viscosity data for $\mathrm{MgCl}_{2}$ are plotted in Figures 24 and 25 . The density data of the N.B.S. (Equation [6] $)^{27}$ was chosen over that of Strelets ${ }^{20}$. The viscosity data of D. Dumas ${ }^{82}$ was chosen for its agreement with the data of P.X. Kymaeb et. al. ${ }^{83}$ and Kh.L. Strelets ${ }^{20}$, while the viscosity data of A.A. Maurits ${ }^{81}$ was ignored. The viscosity (cP) of $\mathrm{MgCl}_{2}$ was correlated with absolute temperature $(\mathrm{K})$ :

$$
\mu \quad=\quad 0.204 \mathrm{e}^{(19361 /(\mathrm{R}))} \cdot \mathrm{R}^{2}=0.994
$$

The power number data have been re-plotted against impeller Reynolds number in Figure 26. Theoretically, the power number should be independant of the fluid (for Newtonian fluids), be identical for the same impeller Reynolds number and be independant of Reynolds number above a value of about 10,000 . The power number data in Figures 23 and 26 obtained by the electrical method, show large variations up to a Reynolds number of almost 100,000 and have a stronger relationship with impeller R.P.M. (Figure 23) than Reynolds number (Figure 26). This would tend to indicate that a systematic error, dependant on impeller speed was introduced using the electrical method. 


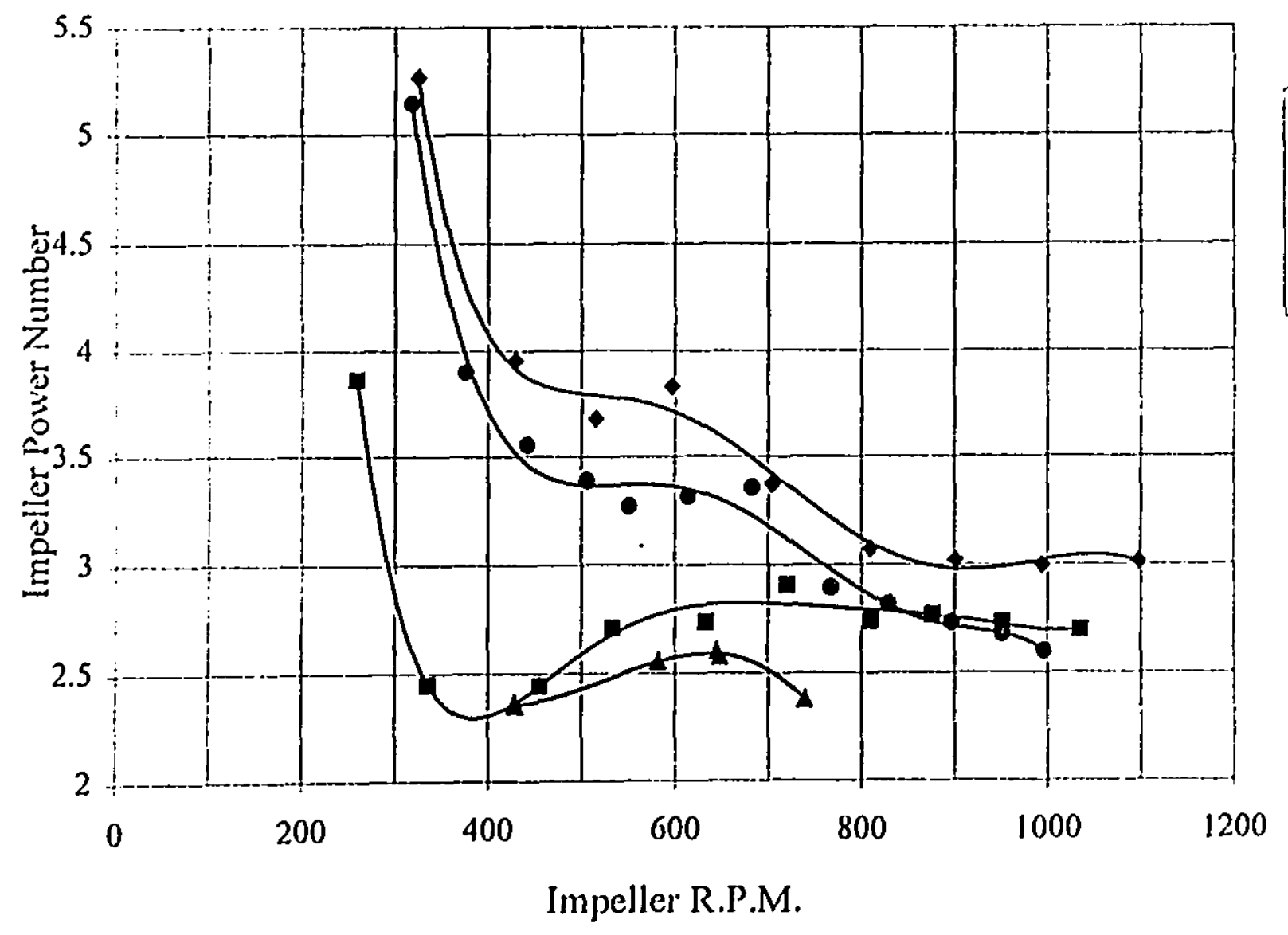

- Water (New Impeller)

- $\mathrm{MgCl} 2$ (New Impeller)

A Water - Dyno (New Impeller)

- $\mathrm{MgCl} 2$ (Used Impeller)

Figure 23: Power Number Against Impeller R.P.M. 


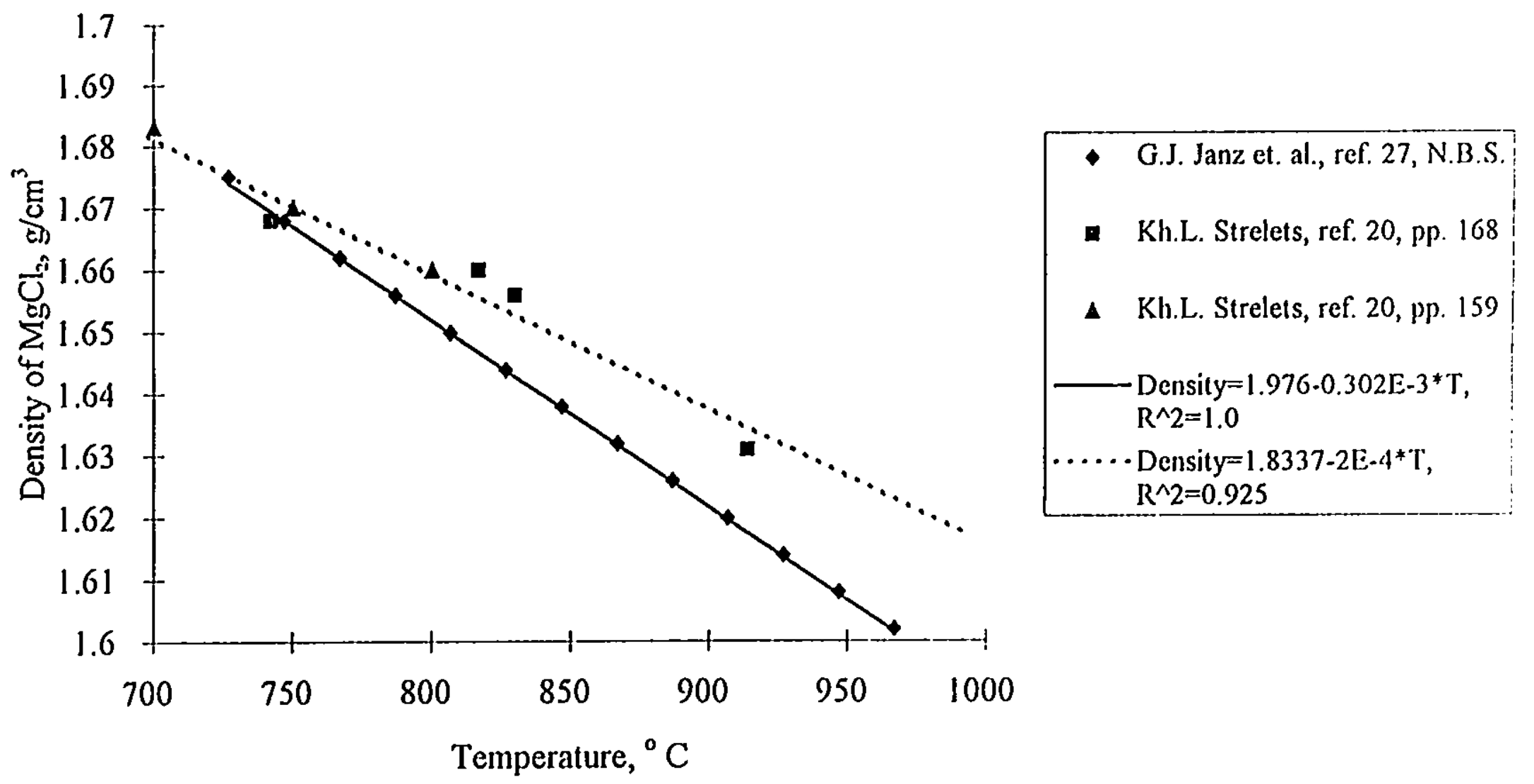

Figure 24: Density of Magnesium Clıloride Against Temperature ${ }^{20,27}$ 


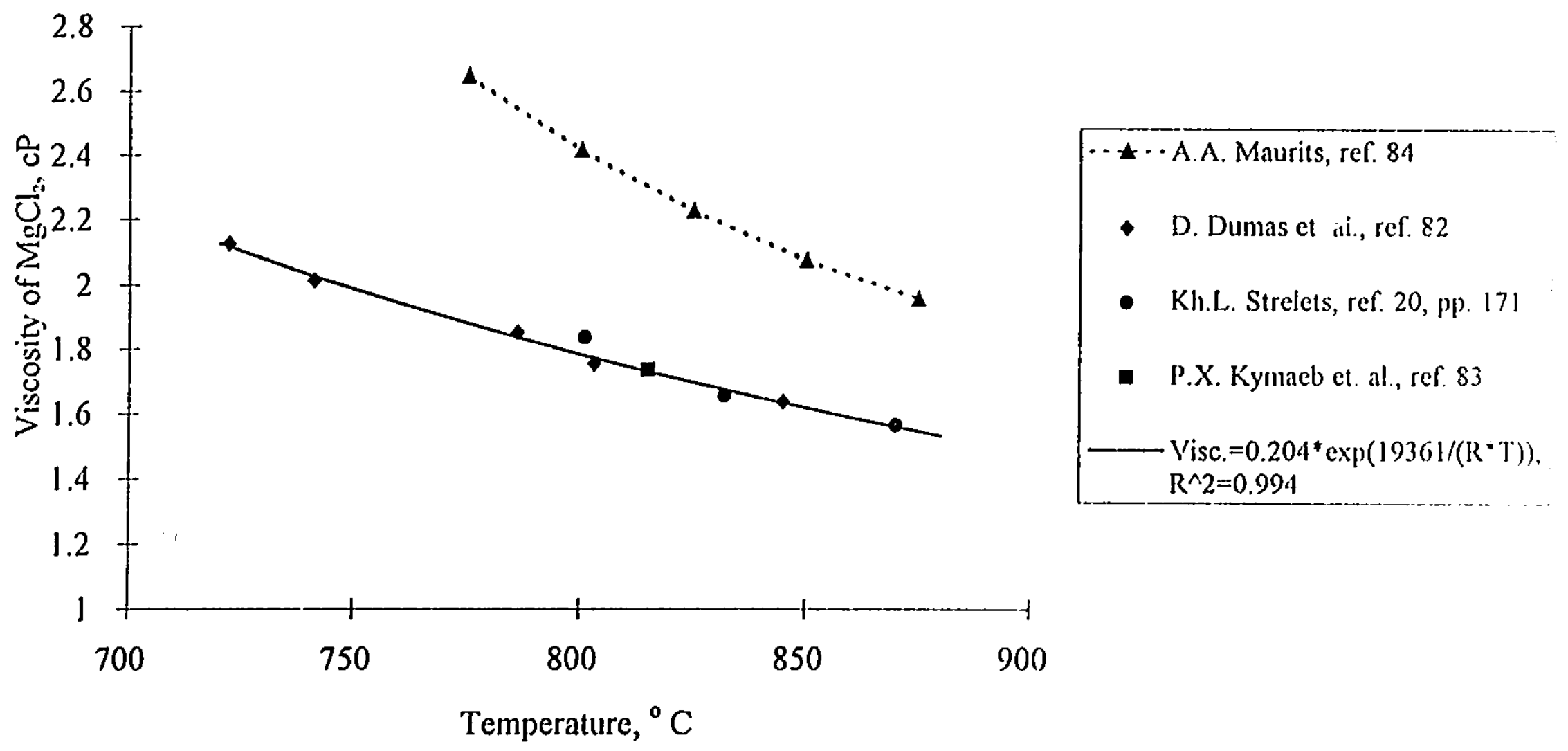

Figure 25: Viscosity of Magnesium Chloride Against Temperature ${ }^{20,82,83,84}$ 


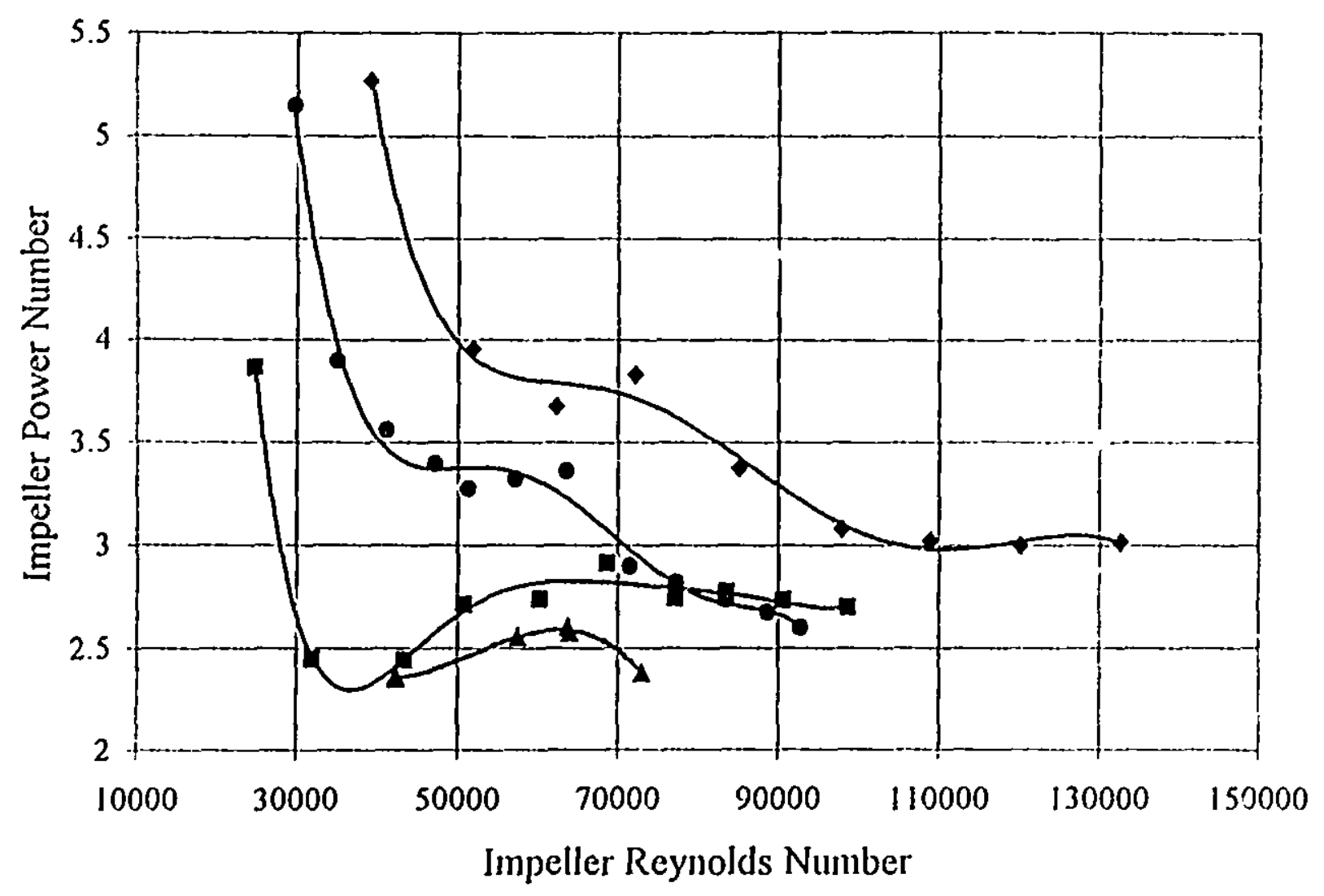

- Water (New Impeller)

- MgCl2 (New Impeller)

a Water - Dyno (New Impclier)

- $\mathrm{MgCl} 2$ (Used Impeller)

Figure 26: Power Number Against Impeller Reynolds Number 


\subsubsection{Un-gassed Mixing Power in Water}

The data obtained for a new impeller in water using a dynamometer are summarized in Table 10 below:

Table 10: Dynamometer Experimental Data

\begin{tabular}{|c|c|c|c|c|c|c|}
\hline \multicolumn{2}{|c|}{ Depth of Water } & $6.5^{\prime \prime}$ & 0.1651 & $\mathrm{~m}$ & \multicolumn{2}{|c|}{$\mathrm{m}$} \\
\hline \multirow{2}{*}{\multicolumn{2}{|c|}{$\begin{array}{l}\text { Impeller Diameter } \\
\text { Tank Diameter }\end{array}$}} & $3^{\prime \prime}$ & 0.0762 & \multicolumn{3}{|l|}{$\mathrm{m}$} \\
\hline & & $6.25 "$ & $0.158 s$ & \multicolumn{3}{|l|}{$\mathrm{m}$} \\
\hline \multicolumn{2}{|c|}{4 Baffles of Width } & $0.625 "$ & 0.0159 & \multicolumn{3}{|l|}{$\mathrm{m}$} \\
\hline \multicolumn{2}{|c|}{$\begin{array}{l}\text { Impeller Height } \\
\text { from Bottom }\end{array}$} & l" & 0.0254 & \multicolumn{3}{|l|}{$\mathrm{m}$} \\
\hline \multicolumn{2}{|c|}{$\begin{array}{l}\text { Length of } \\
\text { Lever Arm }\end{array}$} & $9 . s^{*}$ & 0.2500 & \multicolumn{3}{|l|}{$\mathrm{m}$} \\
\hline R.P.M. & $\begin{array}{c}\text { Mass } \\
\mathrm{g}\end{array}$ & $\begin{array}{l}\text { Force } \\
\mathrm{N}\end{array}$ & $\begin{array}{l}\text { Torque } \\
\text { Nm }\end{array}$ & $\begin{array}{l}\text { Power } \\
\text { IW }\end{array}$ & $\begin{array}{l}\text { Power } \\
\text { Number }\end{array}$ & $\begin{array}{l}\text { Reynolds } \\
\text { Number }\end{array}$ \\
\hline 330 & 10 & $0.09 S$ & 0.025 & 0.85 & 1.99 & 32577 \\
\hline 429 & 20 & 0.196 & 0.049 & 2.20 & 2.35 & 42350 \\
\hline $42 S$ & 20 & 0.196 & 0.049 & 2.20 & 2.36 & 42251 \\
\hline $5 \$ 2$ & 40 & 0.392 & 0.098 & 5.97 & 2.55 & 57453 \\
\hline 645 & 50 & 0.490 & 0.123 & 8.27 & 2.60 & 63672 \\
\hline $64 S$ & 50 & 0.490 & 0.123 & S.31 & 2.57 & 63969 \\
\hline 739 & 60 & $0.58 S$ & 0.147 & 11.38 & 2.38 & 72952 \\
\hline \multicolumn{2}{|c|}{ Temp. of Water } & 23.0 & ${ }^{\circ} \mathrm{C}$ & Average: & 2.47 & \\
\hline \multicolumn{2}{|c|}{ Density of Water } & 997.5 & $\mathrm{~kg} / \mathrm{m}^{3}$ & Std. Dev.: & 0.12 & \\
\hline \multicolumn{2}{|c|}{ Viscosity of Water } & 0.978 & $\mathrm{cP}$ & \multicolumn{2}{|c|}{ 42S-739 R.P.M. } & \\
\hline
\end{tabular}

Using the dynamometer it was found that $10 \mathrm{~g}$ of weight was required to overcome the frictional forces of the bearings supjorting the motor. The actual weights used ranged from $10-60 \mathrm{~g}$ for 330 to 739 R.P.M.. The errors in the power numbers measured using this equipment are highest at the lower speeds, where the $10 \mathrm{~g}$ possible error represents a much higher percentage of the total weight. The average power number at the four highest speeds was 2.47 with a standard deviation of 0.12 . At these speeds, the maximum possible error in weight of $10 \mathrm{~g}$. represents an uncertainty in the power number of $0.6 \mathrm{~S}$. 
Accuracy could have been increased if higher speeds were possible (power and therefore the required weight increase to the 3rd power of speed). Unfortunately the dynamometer apparatus had a natural harmonic at a speed just above 739 R.P.M. and became too unstable to be used. The small $10 \mathrm{~g}$ error in mass is normally insignificant using this apparatus. since using an impeller twice the diameter of the one used in these experiments, would result in masses $2^{5}(32)$ times as much being required (320-1920 g) and render the $10 \mathrm{~g}$ uncertainty negligible.

Using the electrical method on the drive mechanism from tixe chlorination experiments. the same new graphite impeller was found to have a power nutnber of about 3.58 with a standard deviation of 0.36 over the same R.P.M. range. However, it is obvious from Figure 24 that the power number did not siabilize until about 700-800 R.P.M.. Above 800 R.P.M. the impeller was found to have a power number of 3.03 with a standard deviation of 0.03 . The total power required to spin the impeller in water $\left(\mathrm{P}_{\mathrm{J}}\right)$, the equivalent power to spin the impeller in air $\left(\mathrm{P}_{3}\right)$ and the un-gassed mixing power $\left(\mathrm{P}_{0}\right)$ are shown in Figure 27. Above 800 R.P.M. the expected 3rd power relationship between rotatioral speed and mixing powet became evident (see Equation 24). With the increased rigidity and "trueness" of the drive mechanism from the chlorination experiments, the first harmonic was at abcst 1200 R.P.M., and thus speeds well above those in used with the dynamometer could be tested.

The errors associated with the electrical method were probably due to the very low wattages being measured and the high proportion of the tota! power represented by the power in air. The proportion of the total power attributed to the actual mixing power ranged from a low of $13 \%$ to a high of $42 \%$ for this case. Thus any error associated in correcting for the electricai and mechanical efficiencies of the motor will be proportinnately higher at the low R.P.M - It should also be noted that the power in air is independant of impeller size and the actual mixing power increases to the 5th power of diameter (see Equation 24), thus the errors associated with this method have been magnified due to the small diameter of the impeller used in these experiments. 


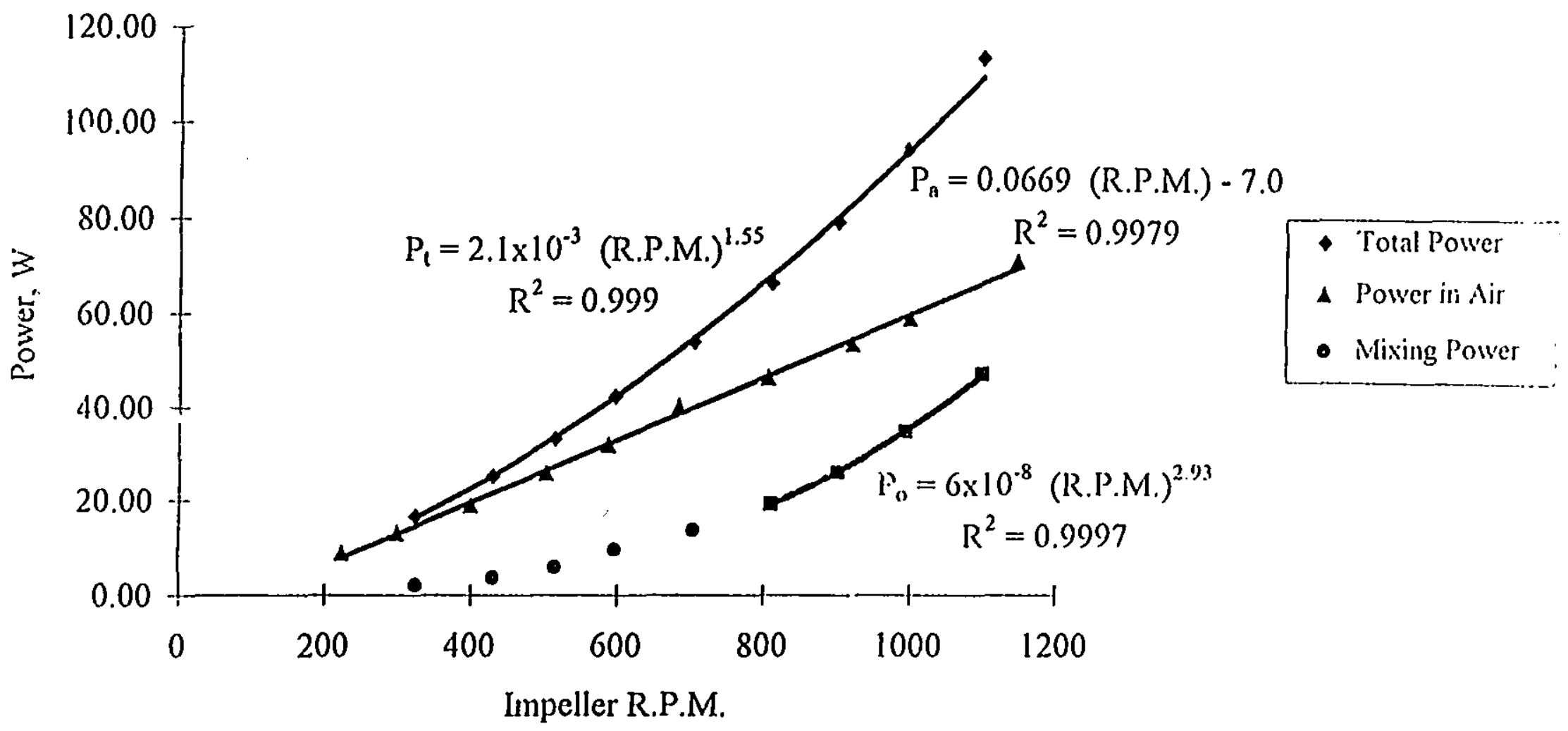

Figure 27: Electrical Power Against Speed For New Graphite Impeller in Water 


\subsubsection{Un-gassed Mixing Power in $\mathrm{MgCl}_{2}$}

The un-gassed mixing power was obtained for both a new and a used impeller (used in about a dozen experiments). These results are also plotted in Figure 23. Above about 700 R.P.M. the two data sets are statistically indistinguishable and in the 700-1100 R.P.M. range, the impeller power number (for both new and used impellers) in $\mathrm{MgCl}_{2}$, is estimated as 2.76 . with a standard deviation of 0.10 .

The experimental data for the new impeller in $\mathrm{MgCl}_{2}$ are plotted in Figure 28. The third power relationship of mixing power with impelier speed was evident over the entire range of speeds. Due to the higher density of $\mathrm{MgCl}_{2}$, mixing power is about $64 \%$ higher than in water at any given speed, thus increasing the accuracy over the results in water. The mixing power :epresented $11-50 \%$ of the total power measured in this experiment.

Possible sources of error included changes in drive belt transmission efficiency, electrical measurement errors, changes in electrical efficiency of the motor and variability in the resistance to rotary motion (changes in bearing grease viscosity with temperature and load).

With reference to the power numbers obtained in water, the power number obtained in $\mathrm{MgCl}_{2}$ (2.76) would appear have an uncertainty of about $+/-10 \%$ in the range of $800-1100$ R.P.M..

\subsection{Gassed Mixing Power in $\mathrm{MgCl}_{2}$}

Gassed and un-gassed mixing power were measured for a new impeller in $\mathrm{MgCl}_{2}$ at 600,800 and 1000 R.P.M, at approximately $830^{\circ} \mathrm{C}$, for gas flow rates of $\mathrm{Cl}_{2}$ and $\mathrm{CO}$ each of: 0.5 , 1.0. 1.5, 2.0 and $2.25 \mathrm{~L} / \mathrm{min}$ (at S.T.P.). The ratio of gassed to un-gassed power has been plotted in Figure 29 for the three speeds and five gas flow rates. 


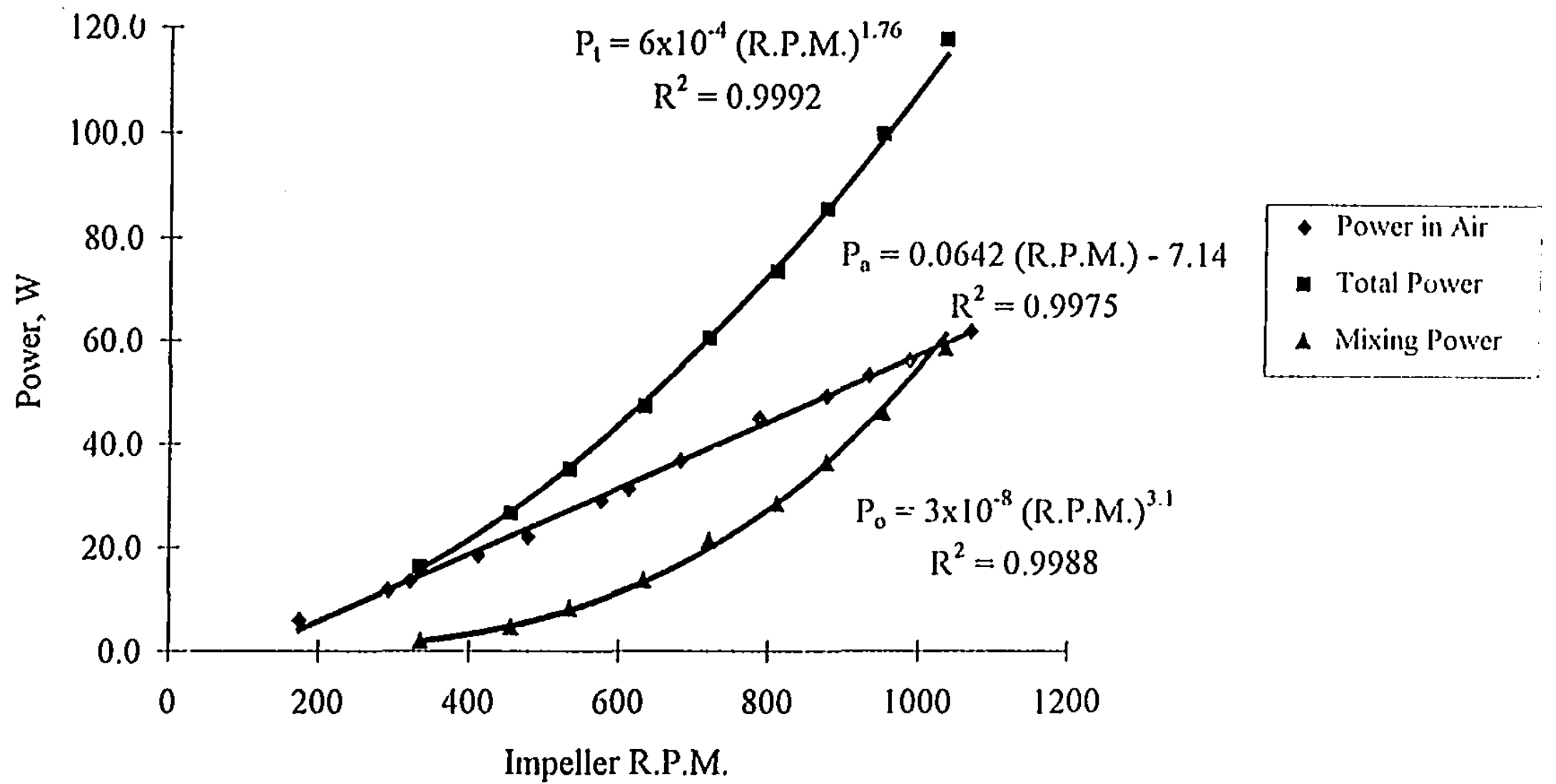

Figure 28: Electrical Power Against Speed For New Graphite Impeller in $\mathrm{MgCl}_{2}$ 


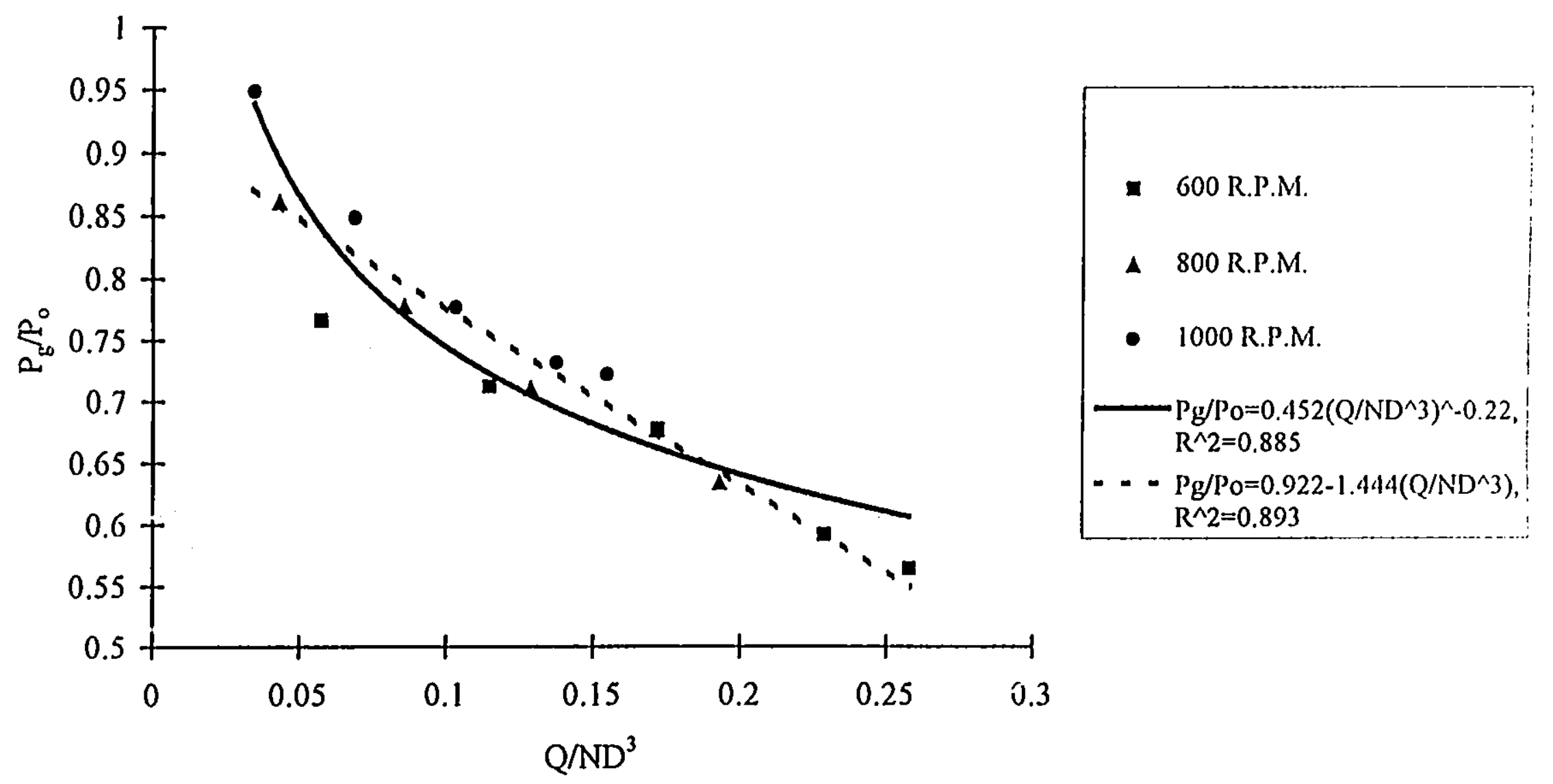

Figure 29: Ratio of Gassed to Un-gassed Power for $\mathrm{New}$ Graphite Impeller in $\mathrm{MgCl}_{2}$ 
The $j$ sets of data have been correlated using the aeration number. Two correlations were ubtained. one linear and one exponential as shown in Figure 29:

$$
\begin{array}{llll}
\mathrm{P}_{\mathrm{R}} / \mathrm{P}_{\mathrm{o}}= & 0.452\left(\mathrm{Q} / \mathrm{ND}^{3}\right)^{-0.22} & \mathrm{R}^{2}=0.885 & {[35]} \\
\mathrm{P}_{\mathrm{R}} / \mathrm{P}_{\mathrm{o}}= & 0.922-1.444\left(\mathrm{Q} / \mathrm{ND}^{3}\right) & \mathrm{R}^{2}=0.893 & {[36]}
\end{array}
$$

The exponent in Equation [35] wil! be influenced by the exact impeller/tank geometry used; however, the magnitude of the exponent in Equation [35] does fall within the published range $\left(-0.22\right.$ to $\left.-0.38^{60.68}\right)$ for flat six blade turbines.

The standard error for Equation [36] is 0.035 .

\subsection{Visualization of Gas Dispersion}

A series of photographs were taken of the water model in operation at a variety of impeller speeds and gas flow rates, taken to be representative of those used in the hot modeling. Speeds from 200-1000 R.P.M and gas injection rates from 8-24 L/min (actual flows) were used. These gas flows are equivalent to $1-3 \mathrm{~L} / \mathrm{min}$ (at S.T.P.) each of $\mathrm{Cl}_{2}$ and $\mathrm{CO}\left(2-6 \mathrm{~L} / \mathrm{min}\right.$ total), injected into a hot chlorinator at $820^{\circ} \mathrm{C}$.

According to Nienow's Equations [26]-[28] at 16 actual L/min the impeller speeds at which flooding ends, and complete gas dispersion and gross recirculation begin are: $N_{F}=$ 194 R.P.M., $\mathrm{N}_{C D}=426$ R.P.M., and $\mathrm{N}_{\mathrm{R}}=475$ R.P.M.. respectively. These numbers are for a Rushton turbine and must therefore be treated with caution, since fluid flow patterns and resulting gas dispersion characteristics are highly dependant on impeller geometry.

The actual flooding point for the special graphite impeller used in these experiments was found to be at approximately 200 R.P.M at 16 actual L/min as shown in Figure 30 . At 600 R.P.M. (Figure 31) the impeller was nearing the transition to complete dispersion and at 800 R.P.M. the flow regime had transformed to gross recirculation (Figure 32). At 
1000 R.P.M. the impeller was in the gross recirculation bubble regime at all gas flows up to 24 actual $\mathrm{L} / \mathrm{min}$ (Figure 33 ). It is therefore assumed that gas dispersion in the actual chlorinator is predominately in the gross recirculation bubble regime (sce Figure 12 in Chapter 3). The flow patems produced by the graphite impeller where very similar to those produced by a normal flat blade turbine. 


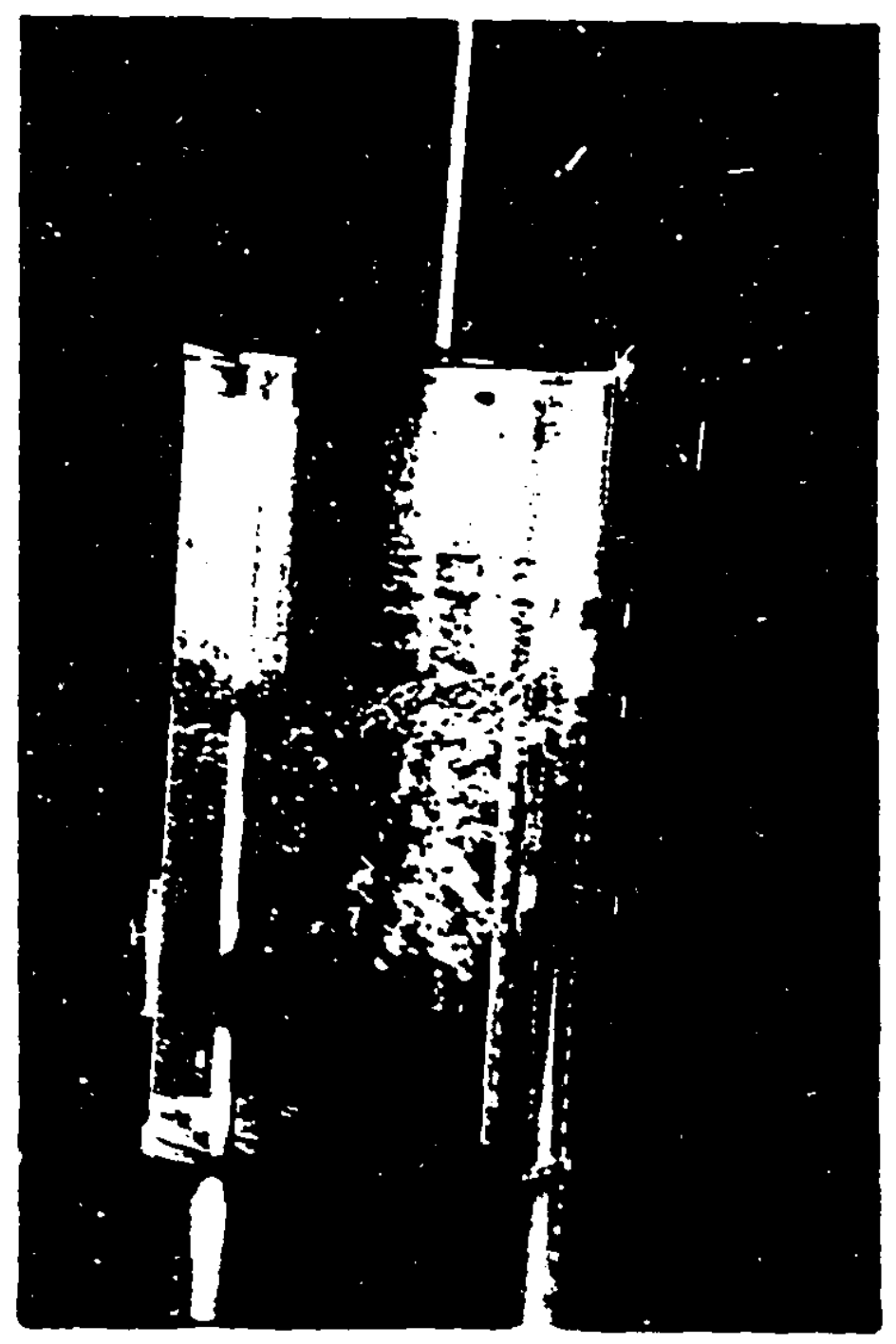

Figure 30: Gas Dispersion at 200 R.P.M. and 16 Actual L/min 


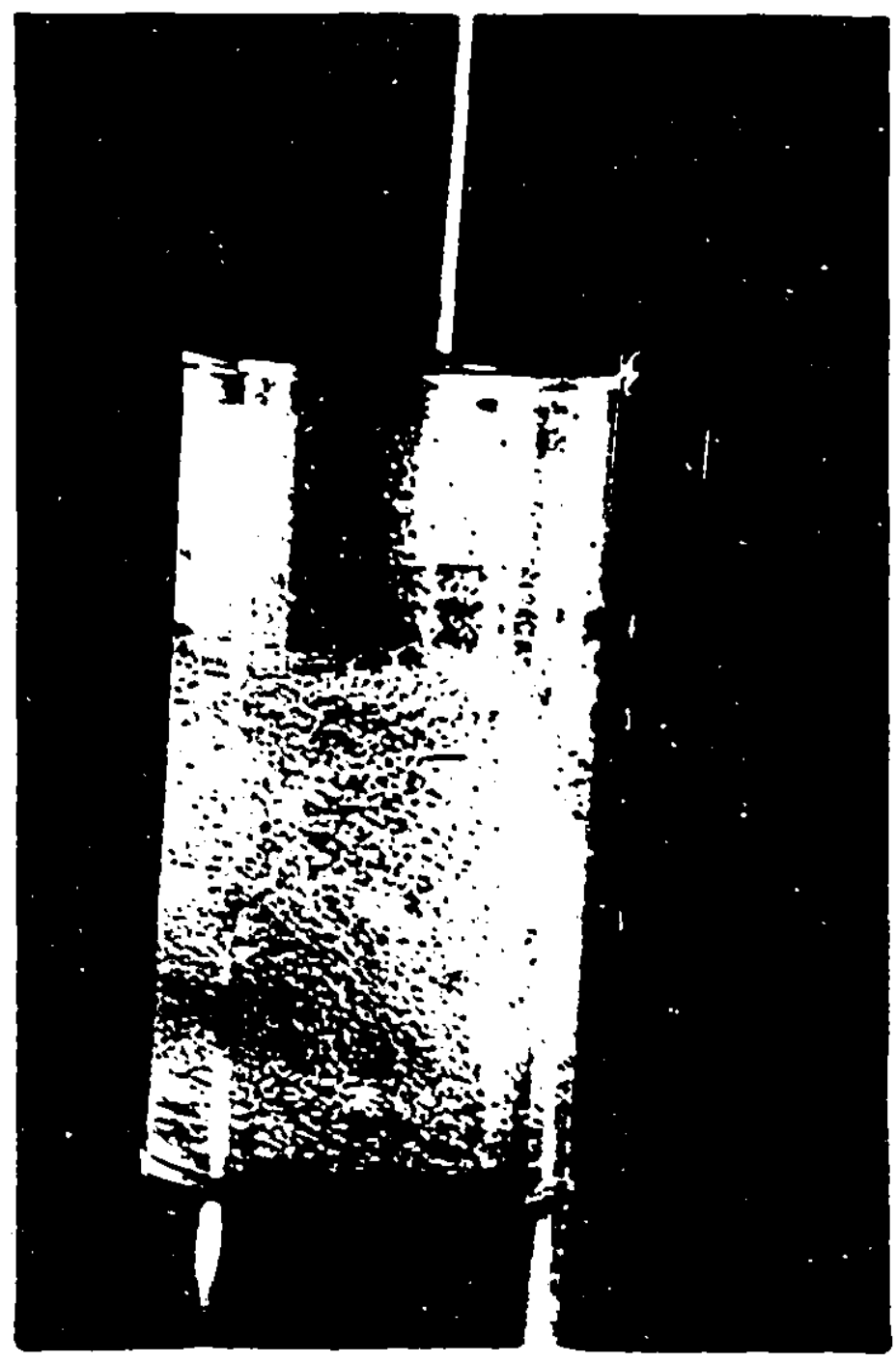

Figure 31: Gas Dispersion at 600 R.P.M. and 16 Actual L/min 


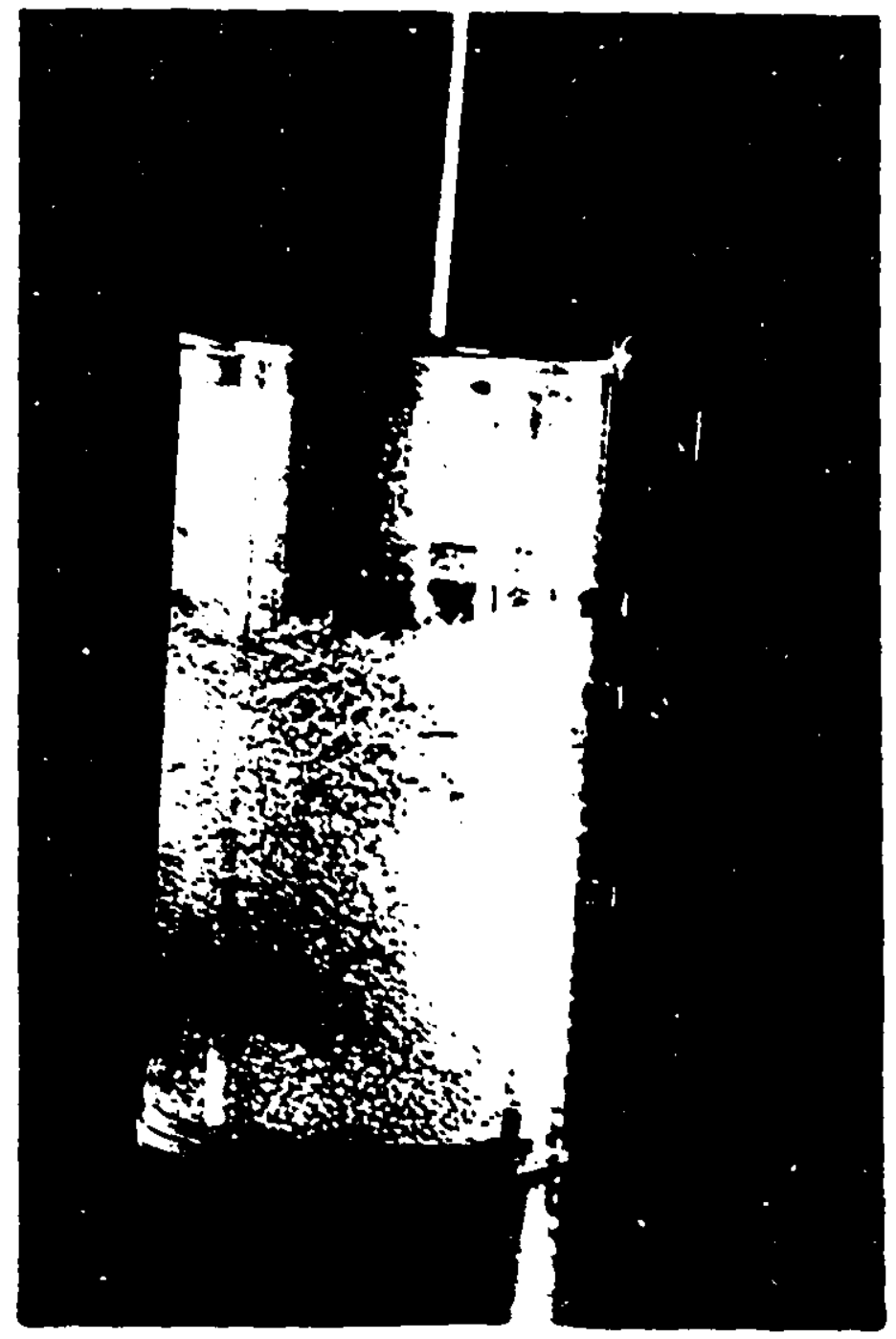

Figure 32: Gas Dispersion at 800 R.P.M. and 16 Actual L/min 


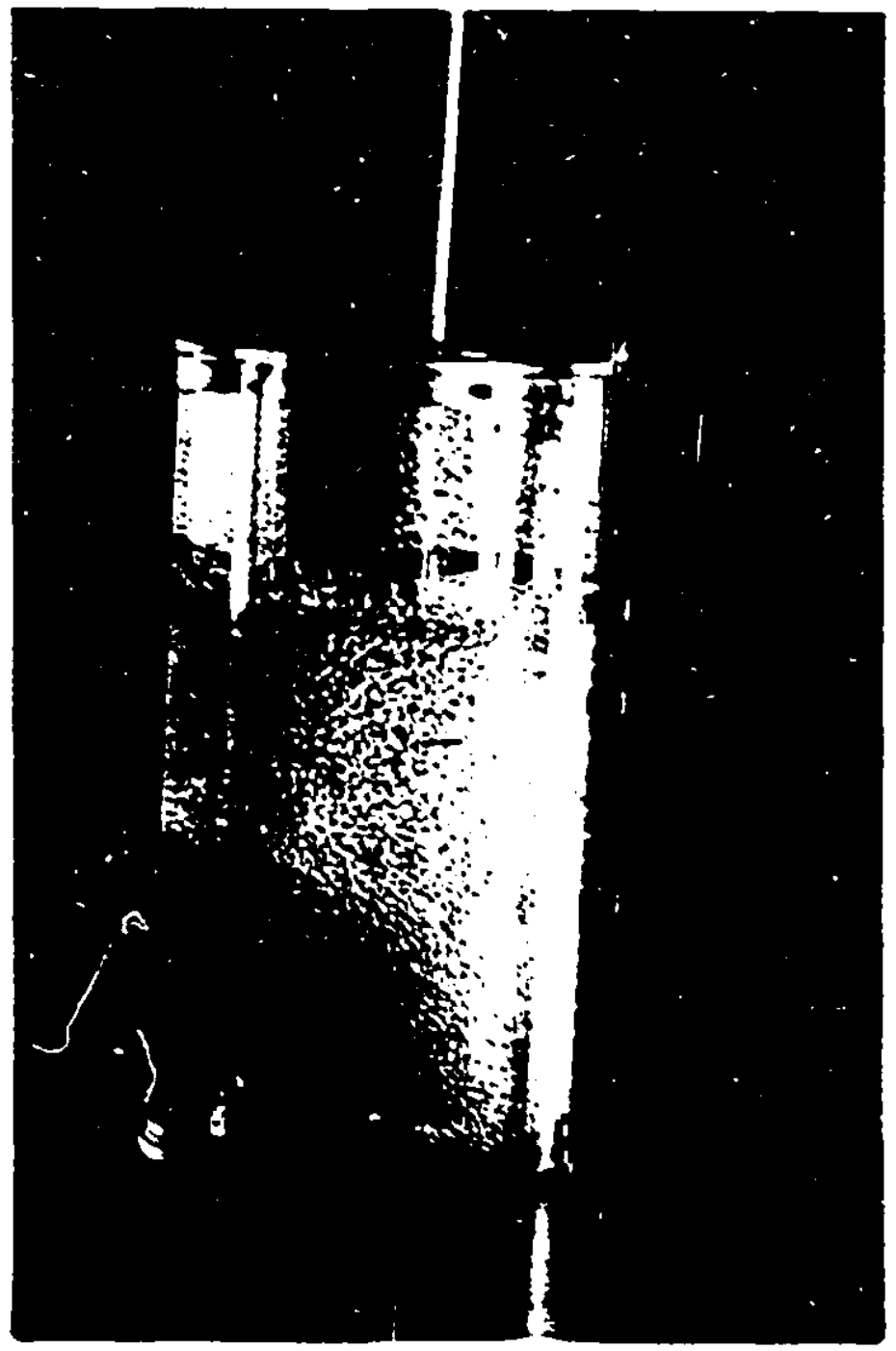

Figure 33: Gas Dispersion at 1000 R.P.M. and 24 Actual L/min 


\section{Chapter $7 \quad$ Results Part II: Chlorination Experiments}

A series of 33 experiments were performed to study the parameters affecting the rate of reaction of $\mathrm{MgO}$ (formed by the thermal decomposition of $\mathrm{MgCO}_{3}$ ) with $\mathrm{Cl}_{2}$ and $\mathrm{CO}$ gases, in a liquid bath of magnesium chloride, using the stirred tank reactor described in Chapter 5. The conditions under which the experiments took place are summarized in Table 11 and the experimental results are summarized in Table 12.

The following independant parameters were studied:

1) MgO concentiation.

2) initial $\mathrm{MgCO}_{3}$ particle size.

3) total gas flow rate,

4) ratio of $\mathrm{CO} / \mathrm{Cl}_{2}$,

5) dilution with an inert gas $\left(\mathrm{N}_{2}\right)$,

6) impeller speed.

7) temperature, and

8) initial Fe concentration.

Other parameters which could have an impact on reaction rate. but which were not directly studied include:

1) ratio of initial melt height to tank diameter,

2) impeller wear, and

3) concentration of contaminants other than $\mathrm{Fe}$.

The effect of each parameter on the rate of the chlorination reaction is dealt with in the following sections. 
Table 11: Summary of Experimental Conditions

\begin{tabular}{|c|c|c|c|c|c|c|c|c|c|c|}
\hline $\begin{array}{l}\text { Expt. } \\
\text { No. }\end{array}$ & $\begin{array}{c}\mathrm{MgO} \\
\text { Particle } \\
\text { Size } \\
(\mu \mathrm{m})\end{array}$ & $\begin{array}{l}\text { Avg. } \\
\text { Temp. } \\
\left({ }^{\circ} \mathrm{C}\right)\end{array}$ & $\begin{array}{l}\text { Temp. } \\
\text { Std. } \\
\text { Dev. } \\
\left({ }^{\circ} \mathrm{C}\right)\end{array}$ & $\begin{array}{c}\text { Avg. } \\
\text { Imp. } \\
\text { Speed } \\
\text { (R.P.M.) }\end{array}$ & $\begin{array}{c}\text { Avg. } \\
\mathrm{Cl}_{2} \\
\text { Flow } \\
(\mathrm{mL} / \mathrm{min})\end{array}$ & $\begin{array}{c}\text { Avg. } \\
\text { CO } \\
\text { Flow } \\
(\mathrm{mL} / \mathrm{min})\end{array}$ & $\begin{array}{c}\text { Avg. } \\
\mathrm{N}_{2} \\
\text { Flow } \\
\text { (mL'min) }\end{array}$ & $\begin{array}{l}\text { Intial } \\
\mathrm{MgCl}_{2} \\
\text { Height } \\
(\mathrm{mm})\end{array}$ & $\begin{array}{l}\text { Initial } \\
\text { MgO } \\
\text { Content } \\
\text { (wt.\%) }\end{array}$ & $\begin{array}{c}\text { Initial } \\
\text { Fe } \\
\text { Content } \\
\text { (P.P.M.) }\end{array}$ \\
\hline $\mathrm{l}$ & $53-75$ & 829 & 3.39 & 1006 & 1834 & 1858 & 0 & 168 & 4.34 & 223 \\
\hline 2 & $53-75$ & $\$ 50$ & 7.46 & 1005 & 1406 & 1449 & 0 & 173 & 5.26 & 351 \\
\hline 3 & $212-300$ & 815 & 14.69 & 1005 & 1431 & 1441 & 0 & 163 & 4.76 & 403 \\
\hline 4 & $212-300$ & 823 & 2.78 & 1003 & 1830 & 1965 & 2827 & 170 & 5.07 & 349 \\
\hline 5 & $212-300$ & 821 & 5.15 & 1003 & 1831 & 1865 & 0 & 170 & 4.45 & 214 \\
\hline 6 & $212-300$ & 826 & 4.3 & 1005 & 933 & 934 & 0 & 170 & 4.77 & 232 \\
\hline 7 & $53-75$ & $\$ 21$ & 3.1 & 1004 & 1413 & 1495 & 0 & 152 & 4.95 & 300 \\
\hline 8 & $212-300$ & $\$ 24$ & 2.05 & 1004 & 469 & 459 & 0 & 165 & 5.12 & 255 \\
\hline 9 & $212-300$ & 823 & 2.11 & 1004 & 2840 & 2816 & 0 & 165 & 5.10 & 256 \\
\hline 10 & $150-212$ & 908 & 4.72 & 1005 & 1325 & 1865 & 0 & 165 & 4.65 & 239 \\
\hline 11 & $150-212$ & 743 & 3.57 & 1006 & 1840 & 1865 & 0 & 152 & 4.21 & 306 \\
\hline 12 & $150-212$ & 864 & 3.84 & 1005 & 1825 & 1865 & 0 & 178 & 4.01 & 264 \\
\hline 13 & $150-212$ & $\$ 24$ & 1.34 & 1006 & 1834 & 1865 & 0 & 173 & 5.13 & 303 \\
\hline 14 & $150-212$ & 783 & 2.26 & 1004 & 1844 & 1965 & 0 & 163 & 3.85 & 222 \\
\hline 15 & $106-150$ & 824 & 4.81 & 1004 & 1827 & 1865 & 0 & 165 & 4.21 & 227 \\
\hline 16 & $106-150$ & 823 & 4.11 & 1004 & 1413 & 1497 & 987 & 168 & 3.46 & 252 \\
\hline 17 & $106-150$ & 823 & 3.41 & 1004 & 929 & 934 & 1885 & 168 & 2.98 & 249 \\
\hline 18 & $106-150$ & 826 & 2.88 & 1004 & 934 & 934 & 0 & 163 & 3.69 & 245 \\
\hline 19 & $106-150$ & 825 & 2.62 & 1006 & 1411 & 1497 & 0 & 163 & 3.62 & 279 \\
\hline 20 & $106-150$ & 825 & 1.73 & 1004 & 472 & 475 & 0 & 173 & 3.64 & 308 \\
\hline 21 & $106-150$ & 824 & 3.57 & 1004 & 467 & 474 & 2827 & 160 & 5.02 & 333 \\
\hline 22 & $75-106$ & $\$ 24$ & 2.97 & 1004 & 1834 & 1865 & 0 & 163 & 4.06 & 227 \\
\hline 23 & $75-106$ & $\$ 25$ & 2.45 & 1156 & 1834 & 1865 & 0 & 163 & 2.71 & 218 \\
\hline 24 & $75-106$ & 824 & 1.27 & 609 & 1829 & 1865 & 0 & 163 & 3.27 & 251 \\
\hline 25 & $75-106$ & 824 & 1.67 & 804 & 1822 & 1865 & 0 & 157 & 3.15 & 213 \\
\hline 26 & $75-106$ & 824 & 2.31 & 1006 & 1834 & 1865 & 0 & 163 & 4.01 & 441 \\
\hline 27 & $75-106$ & 825 & 1.57 & 1006 & 1834 & 1865 & 0 & 163 & 3.45 & 560 \\
\hline 28 & $53-75$ & 824 & 1.82 & 1002 & 1830 & 1865 & 0 & 168 & 2.32 & 232 \\
\hline 29 & $53-75$ & 824 & 2.21 & 1006 & 1417 & 1497 & 0 & 163 & 2.51 & 312 \\
\hline 30 & $106-150$ & 825 & 1.13 & 1004 & 2226 & 1497 & 0 & 165 & 3.69 & 202 \\
\hline 31 & $106-150$ & 824 & 2.38 & 1002 & 1506 & 2219 & 0 & 160 & 3.78 & 241 \\
\hline 32 & $106-150$ & 823 & 1.97 & 1005 & 1420 & 2219 & 0 & 165 & 3.02 & 296 \\
\hline 33 & $106-150$ & $\$ 23$ & 1.69 & 1005 & 1829 & 1862 & 0 & 163 & 3.76 & 396 \\
\hline
\end{tabular}


Table 12: Summary of Experimental Results

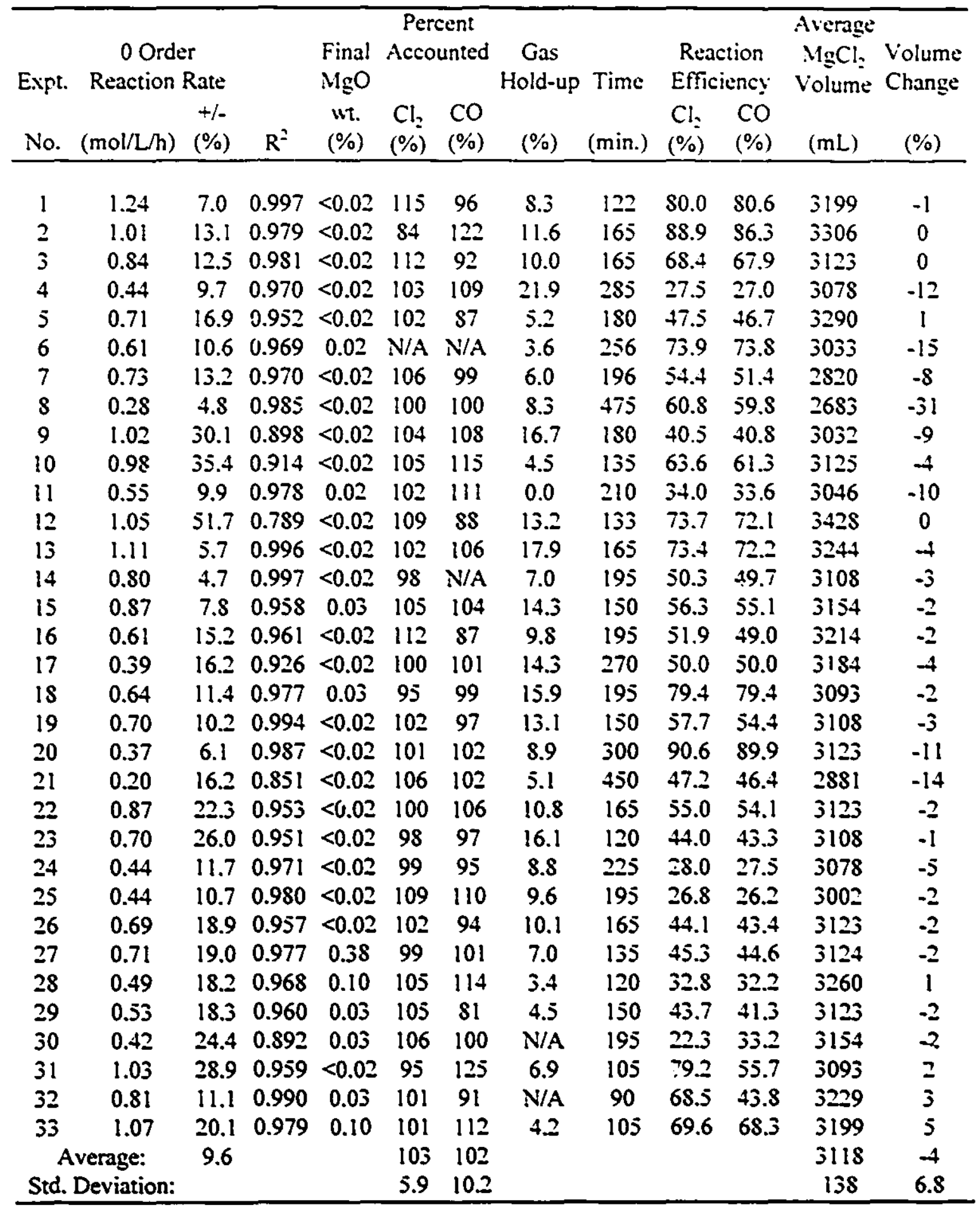


The gas hold-up shown in Table 12 was calculated using lequation $\mid 15]$ and represents the fraction of the expanded molten $\mathrm{MgCl}$ : volume occupied by gas. Only one reading was taken for each experiment due to the hazard involved proximity to rotating equipment). The results are not considered reliable other than as an indication of the actual order of magnitude due to the wave action present within the reactor and are not dealt with further.

The time listed in Table 12. was the time during which gas was sparged into the reactor and not necessarily the duration of the $\mathrm{MgO}$ reaction.

The reaction efficiencies of the $\mathrm{Cl}_{2}$ and $\mathrm{CO}$ were calculated based on the average molar flow rate of the gases (moles $/ \mathrm{min}$.) and the $\mathrm{MgO}$ reaction rate $(\mathrm{mol} / \mathrm{L} / \mathrm{h})$ :

$$
\mathrm{MgO} \text { reacted }(\mathrm{mol} / \mathrm{L} / \mathrm{h})^{*} \mathrm{~V}_{\mathrm{l}}(\mathrm{avg} .) /(\mathrm{Molar} \text { flow of reagent })^{*} 100 \% \quad \text { [37] }
$$

The average volume listed in Table 12 is the average of the initial and final $\mathrm{MgCl}_{2}$ volumes. The average reactor volume was calculated from the initial and final depth measurements and the dimensions of the reactor vessel. Corrections were made for the thermal expansion of the graphite from $25^{\circ} \mathrm{C}$ to the operating temperature, the volume occupied by the baffles and the small volume gained due to a machining groove in the base of the reactor (required to cut the slots for the baffles).

The percent change in the $\mathrm{MgCl}_{2}$ volume is equal to:

(Final Volume - Initial Volume)/Initial Volume*100\%

The other results listed at the beginning of Table 12, are dealt with in detail in the following sections. 


\subsection{Effect of MgO Concentration}

The chlorination rate of the $\mathrm{MgO}$ particles was found to be independant of the amount of $\mathrm{MgO}$ present in the reactor after time zero. Therefore the chlorination rate of $\mathrm{MgO}$ was Zero order with respect to the concentration of $\mathrm{MgO}$. The fact that the chlorination rate was independant of the $\mathrm{MgO}$ colcentration is strong evidence that the reaction rate was controlled by a diffusion process taking place at the surface of the gas bubbles.

The reaction rate of the $\mathrm{MgO}(\mathrm{mo} / \mathrm{L} / \mathrm{h})$ was determined from the slope of a least squares regression of the weight percent of the solid $\mathrm{MgO}$. in the liquid $\mathrm{MgCl}_{2}$, against time:

$$
\text { Rate }=(\Delta \% \mathrm{MgO} / \mathrm{min} .) *(60 \mathrm{~min} . / \mathrm{h}) / 100 * \rho(\text { avg. }) / 40.305
$$

The average density was calculated from the weighted average of the $\mathrm{MgO}$ and $\mathrm{MgCl} 2$ densities at the start and end of the period regressed:

$$
\begin{aligned}
& \rho(\text { avg. })=\left(\left(\rho_{\mathrm{MFCl}_{2}}{ }^{(1)} *\left(100-\% \mathrm{MgO}^{(1)}\right)+\rho_{\mathrm{MrO}} * \% \mathrm{MgO}^{(1)}\right)+\right.
\end{aligned}
$$

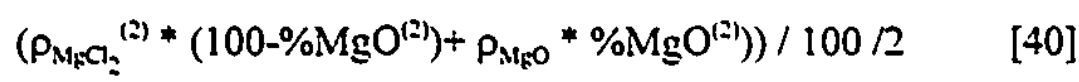

The $\mathrm{MgO}$ reaction rate for Experiment 7 was found to be $0.73 \mathrm{~mol} / \mathrm{L} / \mathrm{h}$ as indicated in Figure 34 . with an accuracy of $+/-13.2 \%$ (from the $95 \%$ confidence interval for the slope of the regression line). The conditions under which Experiment 7 were conducted are listed in Table 11.

The reaction rates, $95 \%$ confidence intervals and $\mathrm{R}^{2}$ values (indicating the $\%$ of the variance in the experimental data explained by the calculated reaction rates) are listed in Table 12 for the 33 experiments performed.

The corresponding temperature and $\mathrm{CO}$ flow information from the computer data logger for Experiment 7, are given in Figure 35 for reference. 


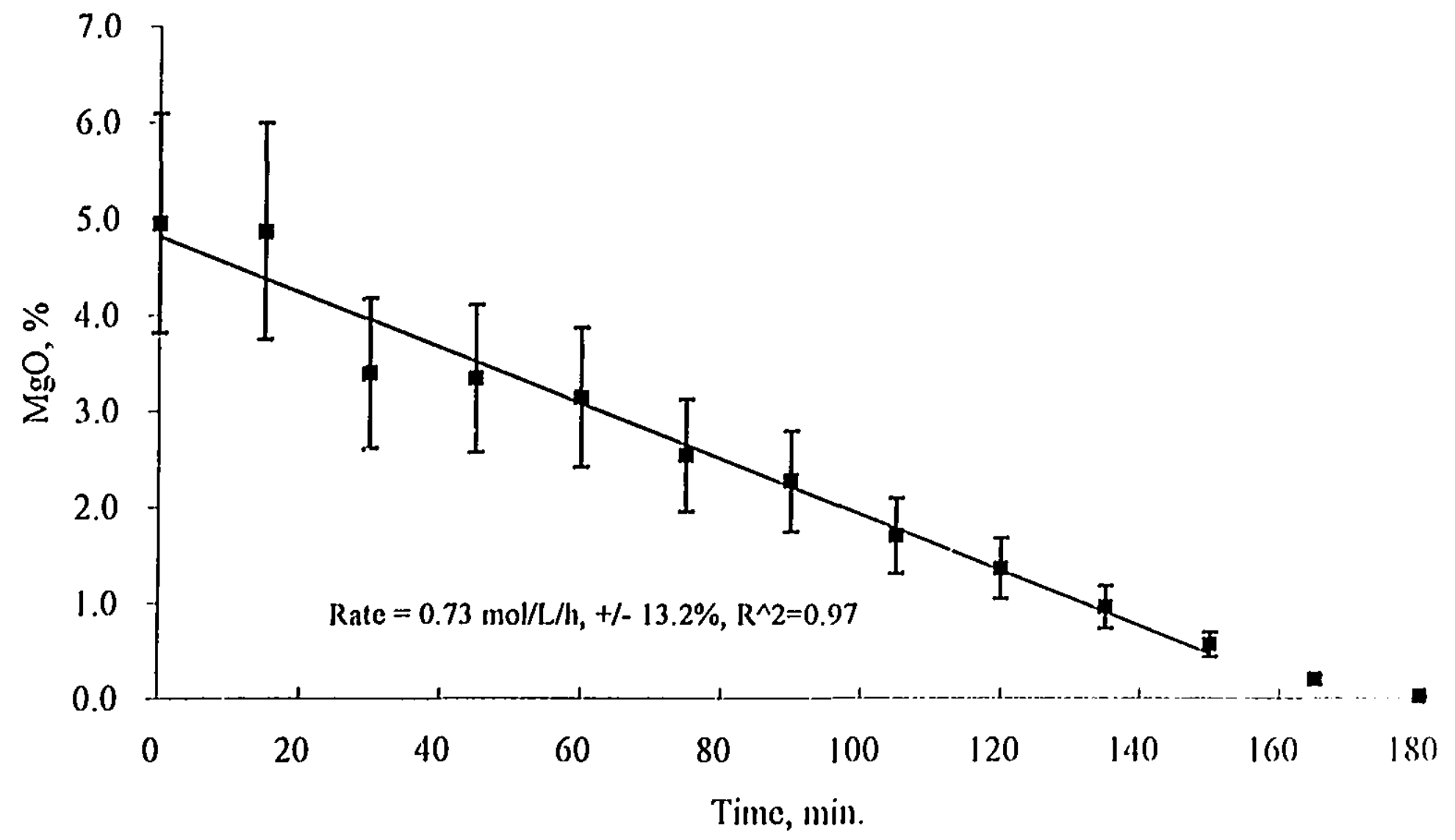

Figure 34: Determination of the MgO Reaction Rate for Experiment 7 


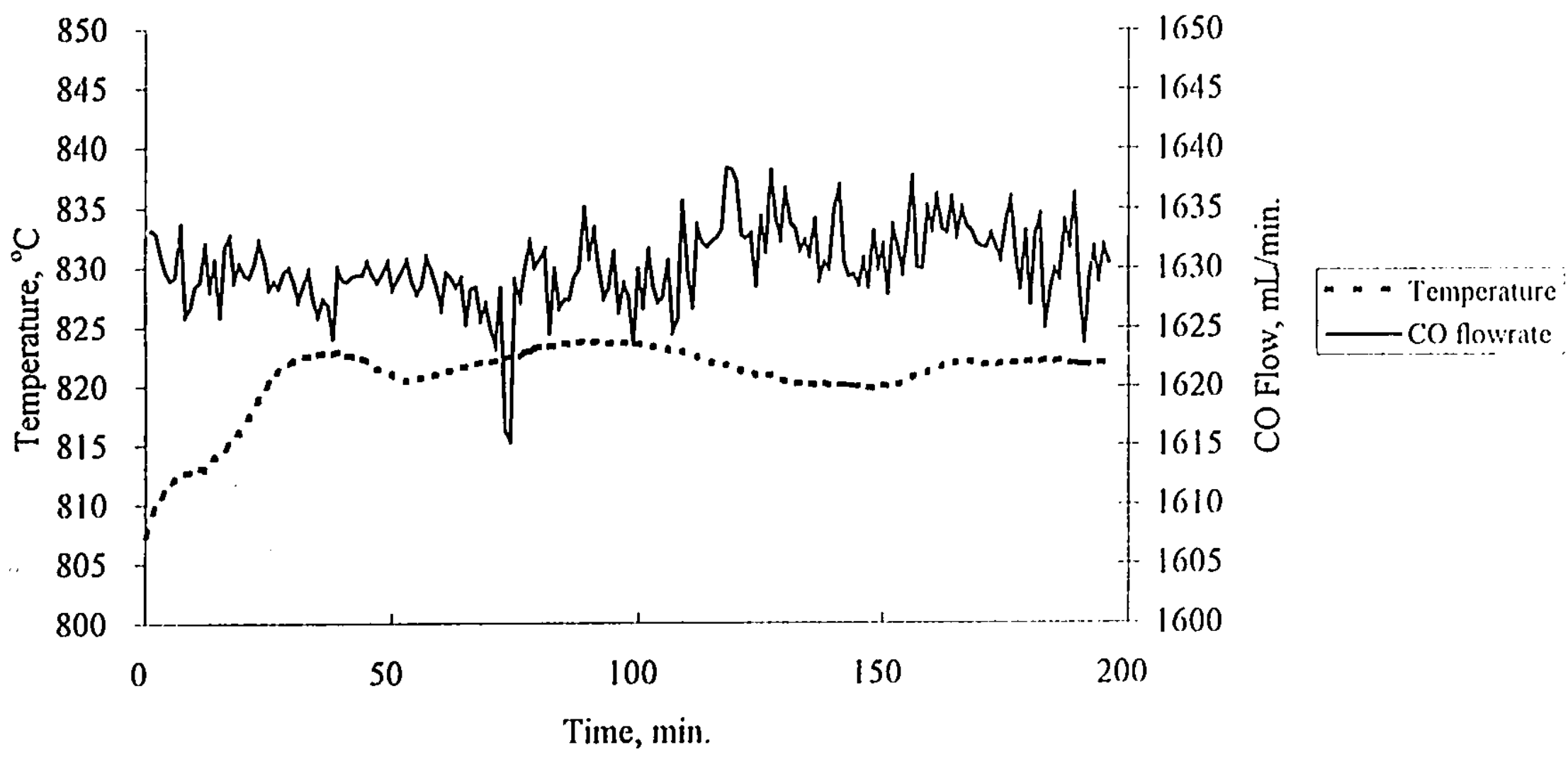

Figure 35: Temperature and CO Flow Rate Against Time for Experiment 7 


\subsubsection{Analysis of variance}

The goal of each experiment was to determine a reaction ratc. that was representative of known conditions. The accuracy of the estimation of the actual rate was affected both by changes in the experimental parameters (temperature. CO flow. $\mathrm{Cl}$, flow: impeller speed) and by any of the uncontrollable time dependant elements within the system (e.g. impeller wear. and electrolyte compesition). The extent to which the samples that were taken represented the actual $\mathrm{MgO}$ content of the reactor and the accuracy with which these samples were analyzed. were both of crucial importance in estimating the actual reaction rate.

Good control was maintained over all of the primary variables (iemperature. $\mathrm{CO}$ flow. $\mathrm{Cl}_{2}$ flow, impeller speed). The temperature standard deviations of the various tests are listed in Table 11 (the average value was $3.25^{\circ} \mathrm{C}$ ). Experiment 3 stands out due to the high standard deviation in temperature caused by a broken thermocouple. This experiment was excluded from the analysis.

Temperature was manually "feed-forward" controlled at the start and end of the experiments, due to the long lag times inherent in the apparatus. The reactor tended to overheat in the initial stages of the experiments, due to the exothermic nature of Reaction (14). and thus the experiments were begun at a temperature slightly below the desired set point in order to prevent a large overshoot. The apparatus had a tendency to cool as the reaction rate fell at the end of the experiments. The standard deviation in temperature for Experiment 7 was $3.1{ }^{\circ} \mathrm{C}(0.28 \%$ in terms of absolute temperature). The temperature history for Experiment 7 was given in Figure 35 . 
The use of a mass flow controller resulted in extremcly precise CO flow control. The standard seviation of the $\mathrm{CO}$ flow for Experiment 7 was only $3.0 \mathrm{~mL} / \mathrm{min}(0.2 \%)$ and is typical of the other experiments.

Chlorine was manually controlled using a rotameter at the set point. $+/-1$ division. (corresponding to $+/-14 \mathrm{~mL} / \mathrm{min}$ for all tests at less than $1420 \mathrm{~mL} / \mathrm{min}$ and $+/-90$ $\mathrm{mL} / \mathrm{min}$ for those tests above this value). This represents a possible random error in flow of $\div /-1-5 \%$. Systematic ertors in flow were minimized by first calibrating the rotameters using a wet gas flow meter and then using the Gilmont flow analysis program.

The total amount of gas used for each test was also measured using the change in mass of the gas cylinders: however. these results were not reliable for individual experiments. due to the relatively low resolution of the balances $\left(0.05 \mathrm{lb}\right.$. for $\mathrm{Cl}_{2}$ and either 0.1 or $0.2 \mathrm{lb}$. for $\mathrm{CO}$ ) and the low masses of $\mathrm{Cl}_{2}$ (average of $2.10 \mathrm{lb}$.) and $\mathrm{CO}$ (average of $0.86 \mathrm{lb}$.) consumed. The resolution of the balances represents an average accuracy of $+1-2.3 \%$ for $\mathrm{Cl}_{2}$ and $+/-12-23 \%$ for $\mathrm{CO}$. The lower resolution scale was used for $\mathrm{CO}$, since the scalc was an immobile floor unit and the $\mathrm{Cl}_{2}$ cylinder was too heavy to be moved for weighing. The resolution of the CO scale was $0.1 \mathrm{lb}$. for experiments $1-9$ and $13-33$ and $0.2 \mathrm{lb}$. otherwise.

The two measurements can be compared in Table 12. The accountabilities of $\mathrm{Cl}_{2}$ and $\mathrm{CO}$ listed in Table 12, were calculated by the following formula:

(AMass of Gas Cylinder)/( Avg. Molar Flow*Molar Mass*Time)*100\% [41]

The volumetric gas flow was the more accurate measurement for an individual test; however, it appears that 2 or $3 \%$ more gas may actually was consumed overall than calculated from the volumetric flow measurements (note the average accountabilities of $\mathrm{CO}$ and $\mathrm{Cl}_{2}$ in Table 12). This was likeiy a systematic offset. 
Impeller speed was manually controlled using a optical digial tachoneter. Speed was controlled equal to the acrage value - - इ R.P.A. (about 0.50 ol for every experiment.

An analysis of variance was performed on duplicate samples taken at the start of each of experiment. The $95 \%$ contidence interval for each sample was found to be - $23 \%$. These calculations assume that the percentage errors for all the start samples are part of the same population. with a mean of zero and a single representative standard deviation. When examined in conjunction with the duplicate assays (of one sample per experiment). it was concluded that approximately $\$ 4 \%$ of the variance in the data was due to sampling and $16 \%$ was due to assaying. A detailed analysis of the sampling variance is included in Appendix B.

The large variance in sampling was probably due to stratitication of the MgO particles within the reactor (inhomogeneity). It was hoped to minimize the random effects of any possible stratification by always sampling from the mid-point of the vessel. In addition. the sampling technique used was not isokinetic and thus further segregation of liquid and solid may have occurred at the moment of sampling: however, an isokinetic sampling method requires knowledge of the velocity profile and was not practical in this case.

The variance found in the assays was probably due to inhomogeneity in the pin tube samples caused by segregation during solidification. This variance could be eliminated by analyzing whole pin tube samples. Variability could also be reduced by taking and analyzing duplicate or triplicate samples and then using the average values to compute the reaction rate.

Future work should include an experiment dedicated to assessing the accuracy of the chosen sampling technique. i.e. multiple samples should be taken from a fixed height within the reactor to determine the total sampling variance and duplicate samples should be taken at several different heights to determine if segregation of the solid particles is 
occurring. In addition. each sample should be analyod at least three times. to obiain a good assessment of the analytical variance.

The accuracy of the estimate of the reaction rate was greatly affected by the number of samples taken for each test. Future researchers should increase the sampling frequency for those tests expected to react quickly or increase the initial quantity of $\mathrm{MgO}$.

Additional variation occurted between subsequent experiments. due to changes in some of the initial conditions. These initial conditions are summarized in Table 11 and include: P.P.M. Fe, \% $\mathrm{MgO}$. and the initial height of $\mathrm{MgCl}_{2}$. The amount of iron initially in the reactor depended on the amount of $\mathrm{MgCO}$; added and the residual amount present from the previous experiment and fell steadily throughout each experiment. The mass of $\mathrm{MgCO}_{3}$ added to the reactors depended on the quantity of each size fraction available and the number of experiments to be performed on each size.

The initial amount of $\mathrm{MgO}$ present in the vessel varied according to the amount of $\mathrm{MgCO}_{3}$ added, as well as the amount lost to dust. A variable amount of $10-25 \%$ of the $\mathrm{MgCO}_{3}$ was lost as dust, due to the evolution of $\mathrm{CO}_{2}$. An average of $17 \%$ was lost and no correlation was found between the amount list and the initial $\mathrm{MgCO}_{3}$ particle size fraction.

The initial height of the $\mathrm{MgCl}_{2}$ depended on the amount left from the previous test and the amount of $\mathrm{MgCO}_{3}$ added. Anhydrous $\mathrm{MgCl}_{2}$ was added to the reactor to increase the height and a quartz ladle was used to remove excess $\mathrm{MgCl}_{2}$. These were only accurate to about $+1-0.25 \%(6 \mathrm{~mm})$. The goal was to have at least an H/T of 1 , so a target height of $6.5^{*}$ (165 mm;-was used. resulting in most of the initial heights being between $159 \mathrm{~mm}$ and $171 \mathrm{~mm}$. Once the impeller was inserted and the reactor's temperature had stabilized, it became extremely difficult to adjust any errors, resulting in some tests with slightly higher initial heights. 
Impeller wear and changes in electrolyte compositions were additional sources of variations between experiments. These variations were not random in that impeller wear progressed steadily (although not inea-!y) and non-volatile chlorides built up sicadily in the electrolyte $\left(\mathrm{CaCl}_{3}, \mathrm{NaCl}, \mathrm{KCl}\right.$. eic $)$ Since the order of the experiments was not randomized as indicated in Tables 11 and 12. these non-random variables may have had a significant impact on the reliability of the results. More statistically reliable results would have been obtained using a statistically designed experimental plan (e.g. BoxBehnken) ${ }^{\text {ss }}$ and then randomizing the order in which the experiments were conducted.

\subsection{Effect of Total Flow and Particle Size}

In order to determine the effect of total gas flow rate and particle size on the chlorinatien rate of the $\mathrm{MgO}$. the ratio of $\mathrm{CO} / \mathrm{Cl}$, was maintained at $\mathrm{l} / 1$ and the total gas flow was increased from approximately 1 to $6 \mathrm{~L} / \mathrm{min}$ (at S.T.P.). in separate experiments, at an average of $\$ 23^{\circ} \mathrm{C}$ and 1004 R.P.M.. and two separate particle size ranges (106-150) $\mu \mathrm{m}$ and $(212-300) \mu \mathrm{m}$.

A total of 10 experiments were conducted at 5 different gas flow rates (Experiments 3.5. 6. 8. 9. 13, 15, 18, 19, and 20) and have been plotted in Figure 36. The reaction rate of the $\mathrm{MgO}$ was found to increase with increasing gas flow rate and was found to be independant of the size of the $\mathrm{MgO}$ particles. The results in Figure 36 have been summarized by two correlations one linear and one noin-linear:

$$
\begin{array}{ll}
\text { Rate }=0.33+1 \times 10^{-4}(\mathrm{Q}), & \mathrm{R}^{2}=0.760 \\
\text { Rate }=5.3 \times 10^{.3}(\mathrm{Q})^{0.63}, & \mathrm{R}^{2}=0.866
\end{array}
$$

It is well known that bubble size increases with increasing gas flow rates. due tc coalescence and the reduction in impeller power. One would therefore assume that there 


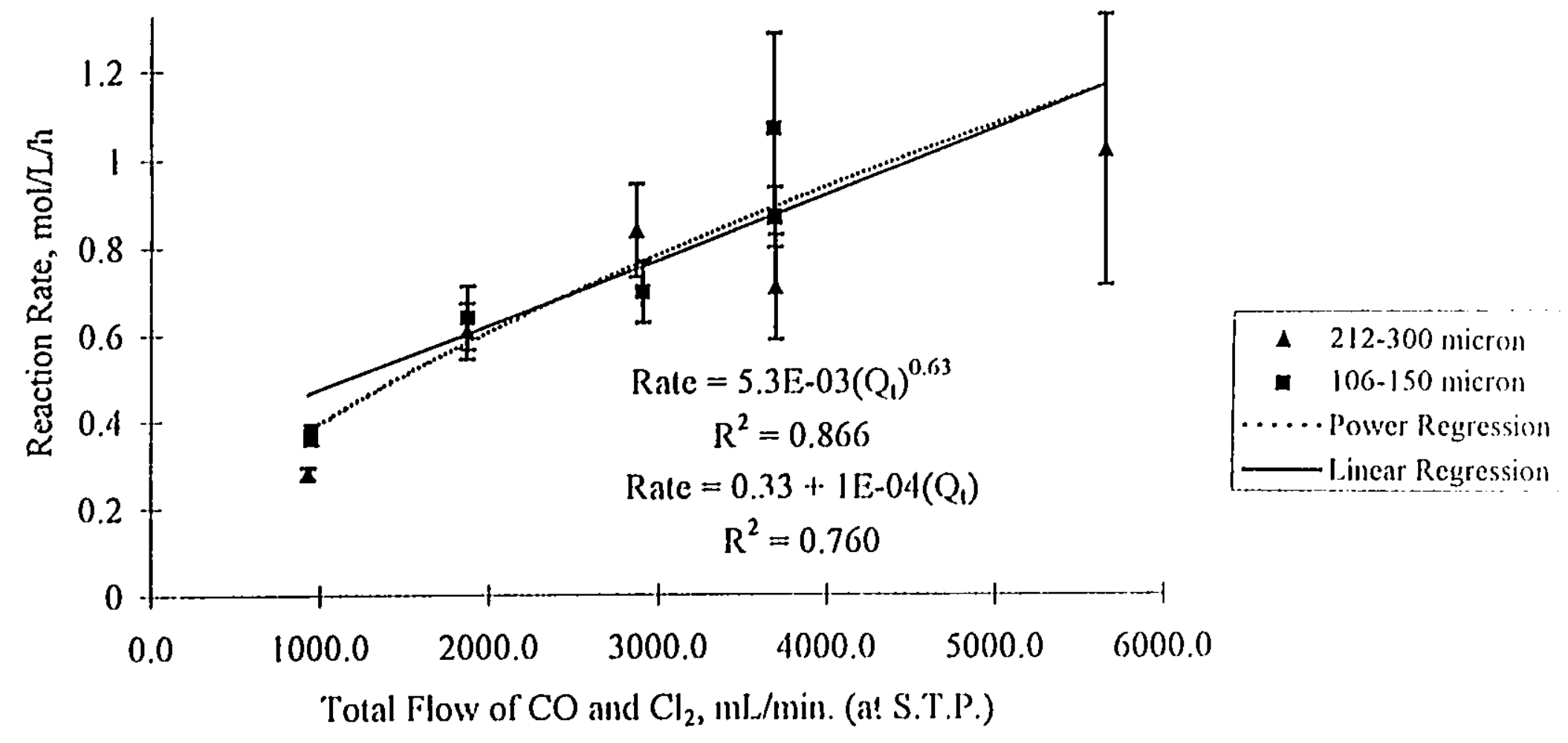

Figure 36: The Effects of Total Gas Flow and MgO Particle Sizc on the Reaction Rate of Mg() 
should be a less than a l" power relationsinip between reaction rate and gas flow. as clearly indicatco by liquation $|+3|$.

Equations $[42]$ and $[43]$ indicate that the reaction rate of the $.19 O$ increases with increasing gas tlow rate. This is a further indication that the overall reaction rate was controlled by a diffusion process taking place at the surface of the gas bubbles.

The relationship between the reaction rates for the two MgO particle size fractions at each gas flow rate. appear to be random from the data plotted in Figure 36 . At some gas injection rates. the smaller size reacted faster and at others the larger size reacted faster. Both cata sets are adequately described by one correlation. leading to the conclusion that the $\mathrm{MgO}$ particle size has no impact on the reaction rate.

It should also be noted that if the reaction rate is independant of the concentration of $\mathrm{MgO}$ (as shown in Section 7.1). then it should also be independant of the physical properties of the MgO such as: size. porosity, actual and apparent surface area. etc..

\subsection{Effect of $\mathrm{CO} / \mathrm{Cl}_{2}$ Ratio}

The bulk of the experimental work presented here. was conducted with a stoichiometric mixture of $\mathrm{CO}$ and $\mathrm{Cl}_{2}$. The results of D.V. Pruttskov et. al. .9 (shown in Section 2.1.2.2) suggested that the chlorination of $\mathrm{MgO}$ (formed from magnesite) is controlled by the diffusion of $\mathrm{CO}$ through the liquid $\mathrm{MgCl}_{2}$ and that an optimum $\mathrm{CO} / \mathrm{Cl}_{2}$, ratio exists. at which the overall rate of reaction is maximized (shown to be between 1 and 2 in Figure 5 for a shaft reactor). Five experiments (15, and 30-33) were therefore conducted at $\mathrm{CO} / \mathrm{Cl}_{2}$ ratios between 0.67 and 1.56 . at $\$ 24^{\circ} \mathrm{C} .1004$ R.P.M.. using the (106-150) $\mu \mathrm{m}$ particle size fraction. in order to determine if such an optimum value existed. These results are presented in Figure 37. 


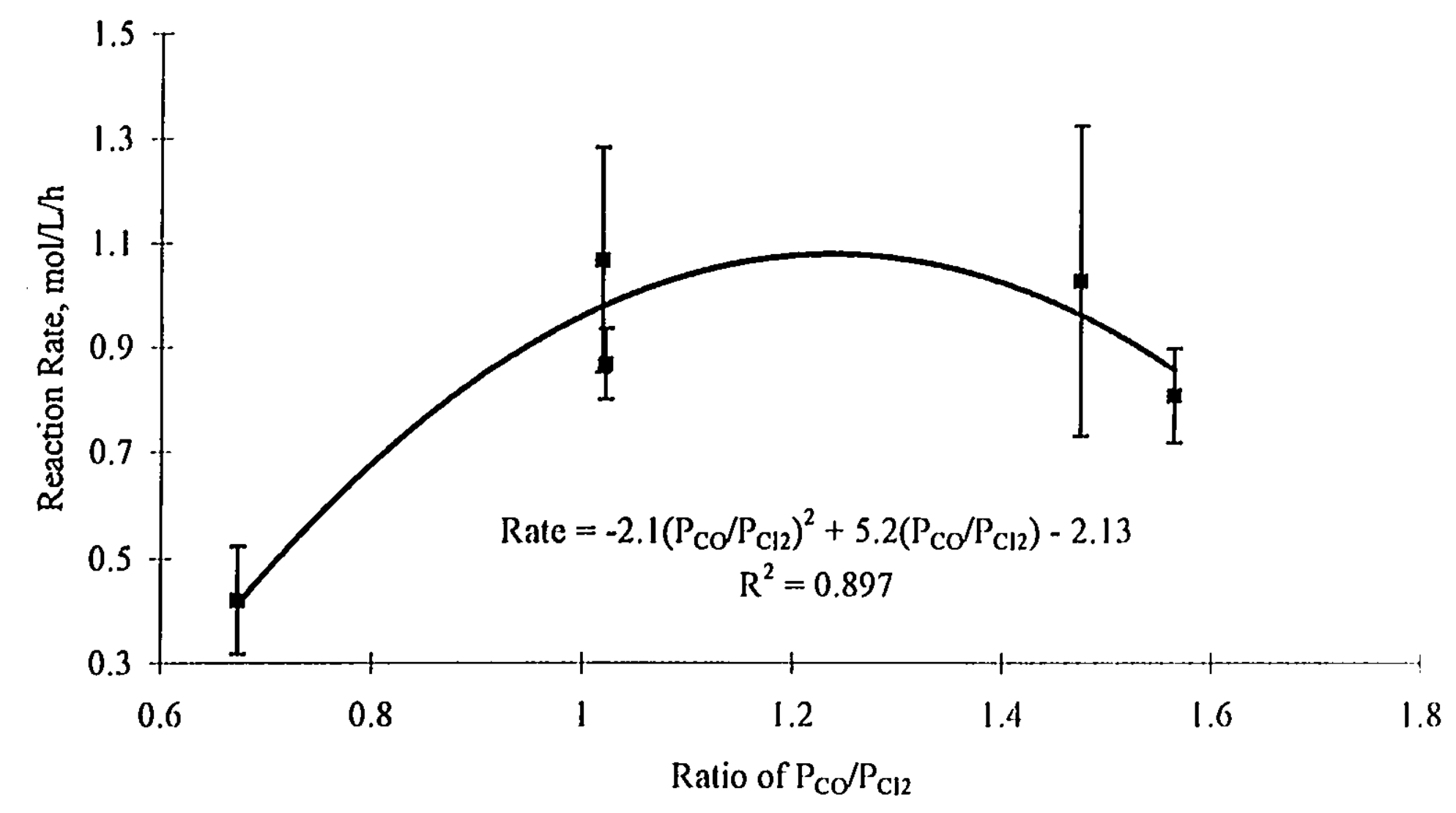

Figure 37: The Effect of $\mathrm{CO} / \mathrm{Cl}_{2}$ Ratio on the Reaction Rate of $\mathrm{MgO}_{\mathrm{g}}$ 
The experimenad date in figure it have heen summarized hy a $2^{\text {mit }}$ order polynomial regression:

$$
\text { Ratc } \left.\left.-=-2.1\left(P_{(1}, P_{0}\right)^{2}+5.21 P_{1}, P_{1}\right)-2.15 R^{2}-0.80\right)
$$

The optimum $\mathrm{CO} C \mathrm{Cl}$, ratio was calculated of be $1.2+$ from the 1 "derivative of Equation 144]: however. given the few data points and high degree of uncertainty shown in the data in Figure 37, the only firm conclusion which can be reached. is that an optimum $\mathrm{CO} C !$ value exists and lies at a $\mathrm{CO} C \mathrm{Cl}$, ratio somewhere between 1.02 and 1.47 .

The fact that the optimum ratio is in the $\mathrm{CO}$ rich domain and that the reaction rate decreases very quickly in the $\mathrm{Cl}_{2}$ rich domain. indicate that the rate of diffusion of the $\mathrm{CO}$ gas from the gas bubbles was the rate controlling step in the chlorination of $\mathrm{MgO}$ in a stirred tank reactor. Further confirmation will be given in the following section.

\subsection{Effect of Dilution with an Inert Gas $\left(\mathrm{N}_{2}\right)$}

Experiments were conducted in order to determine the effect of diluting the $\mathrm{CO}$ and $\mathrm{Cl}_{2}$ gases with an inert gas $\left(N_{2}\right)$. These experiments were intended to determine whether the gas interfacial area or the concentration of the reagent gases. has a greater effect on the chlorination rate. If gas surface area has a more significant impact. it would imply that a species diffusing from the bulk of the electrolyte to t a surface of the gas bubbles controls the rate of chlorination. If the concentration of the $\mathrm{CO}$ and $\mathrm{Cl}_{2}$ were more important. then it would indicate that diffusion of gas from the gas bubbles into the bulk of the electrolyte was rate limiting.

In the first set of experiments (15-17.21 and 33). the total gas flow rate was held constant at an average value of $3759 \mathrm{~mL} / \mathrm{min}$. and increasing amounts of $\mathrm{N}_{2}$ were added to a $1 / 1$ mixture of $\mathrm{CO}$ and $\mathrm{Cl}_{2}$. at about $\$ 23{ }^{\circ} \mathrm{C}$ and 1004 R.P.M. using the (106-150) um particle 
size. A total of four mixtures ranging from $0 \%$ to $75 \% \mathrm{~N}$, were tested and the results are given in Figure 38 . The reaction rate data has been extremely well correlated by a linear correlation:

$$
\text { Rate }=0.943-0.011\left(\% \mathrm{~N}_{2}\right), \mathrm{R}^{2}=0.942
$$

The average $\mathrm{Cl}_{2}$ and $\mathrm{CO}$ reaction efficiency data have also been correlated as follows:

$$
\text { Efficiency }=66.66-0.21\left(\% \mathrm{~N}_{2}\right), \quad \mathrm{R}^{2}=0.605
$$

In this series of experiments, the gas interfacial area would be almost constant, since the same total gas volume was injected in each experiment. If the rate controlling step was diffusion of a species from the electrolyte to the gas bubbles, it would be expected that the efficiency of the utilization of the $\mathrm{CO}$ and $\mathrm{Cl}_{2}$ would increase, with increasing dilution. Equations [45] and [46] indicate that both the efficiency and reaction rate fall with increasing dilution, indicating that diffusion from the bubble into the bulk of the electrolyte, must be the rate limiting step.

A second series of experiments (18-20) were conducted at the same flow rates of $\mathrm{CO}$ and $\mathrm{Cl}_{2}$, as those used in experiments (16-17 and 21). While the gas flow rates of $\mathrm{CO}$ and $\mathrm{Cl}_{2}$ were the same, the total gas flow rates in these second experiments varied from 947-2908 $\mathrm{mL} / \mathrm{min}$, since no $\mathrm{N}_{2}$ was used. The ratio of the reaction rates of the experiments diluted with $\mathrm{N}_{2}$ and those without $\mathrm{N}_{2}$, have been plotted in Figure 39. The graph must have a ratio of 1 , at $0 \% \mathrm{~N}_{2}$ dilution and this point is also shown. A fifth point has been added, representing the ratio of Experiments 4 and 5. Experiment 4 was accidentally conducted with a flow of $2827 \mathrm{~mL} / \mathrm{min}$ of $\mathrm{N}_{2}$, being added to a flow of $3695 \mathrm{~mL} / \mathrm{min}$, of a $1 / 1$ mixture of $\mathrm{CO}$ and $\mathrm{Cl}_{2}$. Experiment 5 was conducted as a repeat of Experiment 4, but without $\mathrm{N}_{2}$. These five data points were regressed to give:

$$
R_{d} / R_{0}=0.988-0.0067\left(\% N_{2}\right), \quad R^{2}=0.911
$$




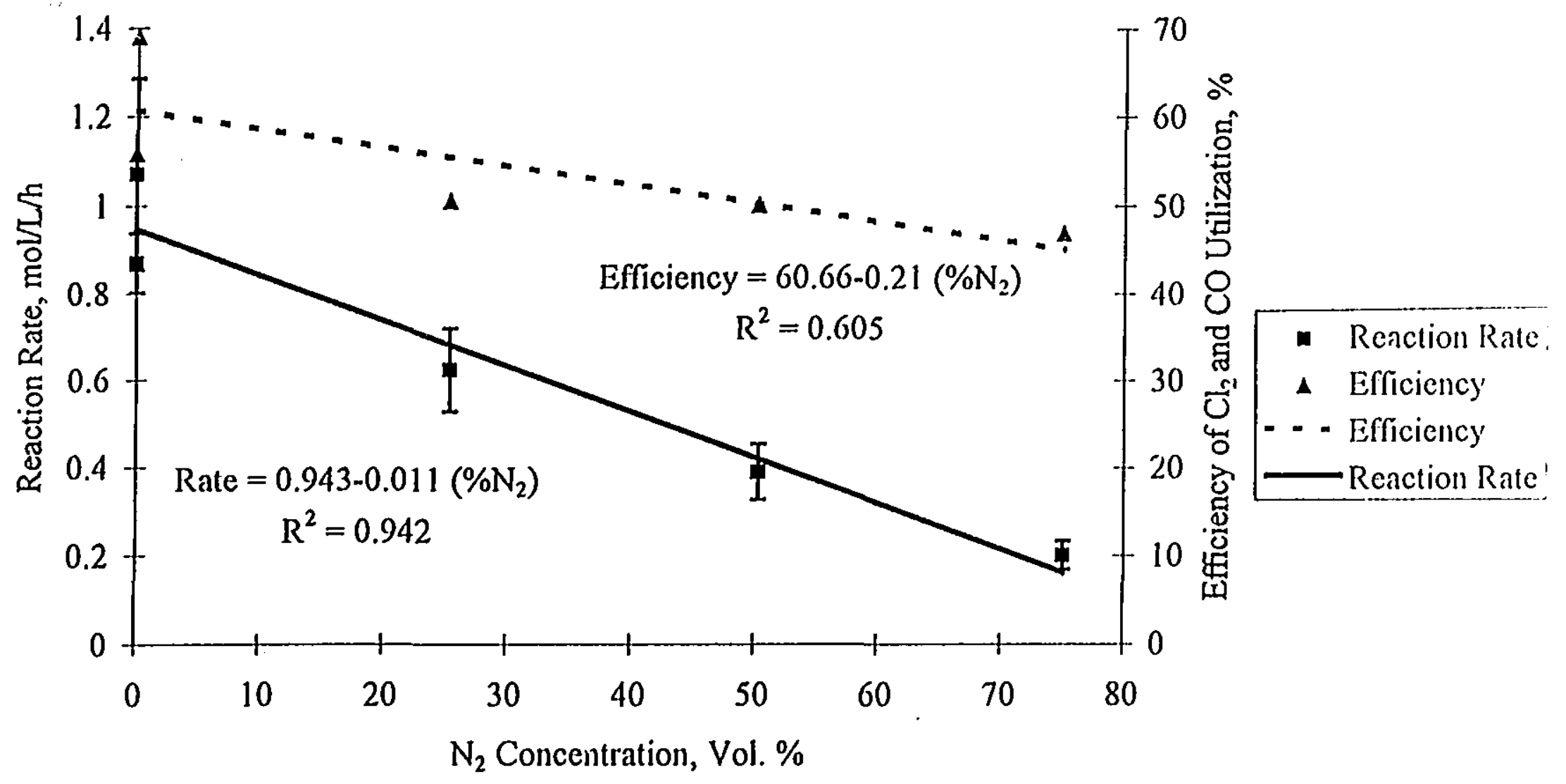

Figure 38: The Effect of Dilution with $\mathrm{N}_{2}$ on the $\mathrm{MgO}$ Renction Rate at Constant Total Gis Flow (3759 mI/min) 


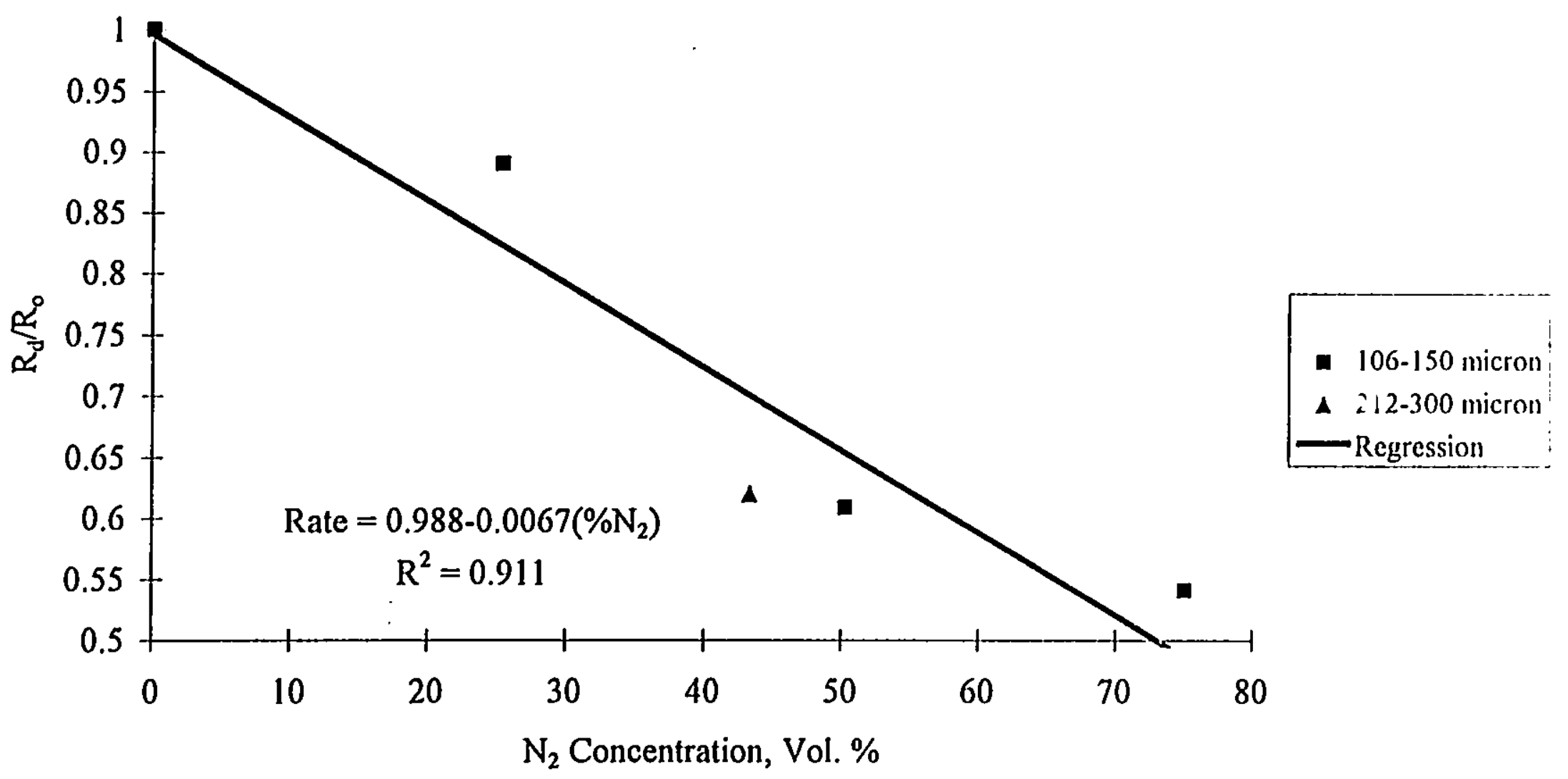

Figure 39: The Effect of Increasing Total Gas Volume Using an Inert Gas on the MgO Renction Rate 
Equation [47] clearly indicates that the reaction rate fell with respect to the equivalent flow of undiluted reagent gases. even though the total volume of gas injected was increased using $\mathrm{N}_{2}$. This is proof that the rate of the chlorination reaction was controlled by diffusion from the within the gas bubbles. to the bulk of the electrolyte. This also clearly illustrates that under no circumstance would there be any advantage in using a non reactive gas in the reaction mixture. as is sometimes done in the aluminum industry (see Section 3.1).

\subsection{Effect of Impeller Speed}

The rate of a reaction controlled by diffusion from the gas to the liquid phase. normally increases at higher impeller speeds. Given that the liquid side mass transfer coefficient $\left(k_{L}\right)$. is considered to be independant of impeller speed ${ }^{57}$ (also implied by Equation $\left.[13]^{59}\right)$, the increase in reaction rate, is due to the decrease in bubble size and increase in gas-liquid interfacial area (see Section 3.2. Equations [10]-[22]). The reaction rate will normally increase by greater than the $1^{\text {st }}$ power of impeller speed. since the un-gassed impeller power increases to the $3^{\text {rd }}$ power of speed (as indicated by Equation [24]) and the gassed power increases proportionately even more (according to Equation [35]) due to the lower aeration number at higher speed.

Four experiments (22-25) were conducted at four different impeller speeds $(609,804$, 1004 , and 1156 R.P.M.) to examine this effect, using the (75-106) $\mu \mathrm{m}$ size fraction, at an average of $824^{\circ} \mathrm{C}$ and using $3695 \mathrm{~mL} / \mathrm{min}$ of a $1 / 1 \mathrm{CO} / \mathrm{Cl}_{2}$ mixture. The results of these experiments are shown in Figure 40.

Figure 40 indicates that the reaction rate increased as the impeller speed was increased from 609 to 1004 R.P.M.; however, it would also appear that somewhere between 1004 and 1156 R.P.M. the reaction rate began to decrease. This result was not expected. 


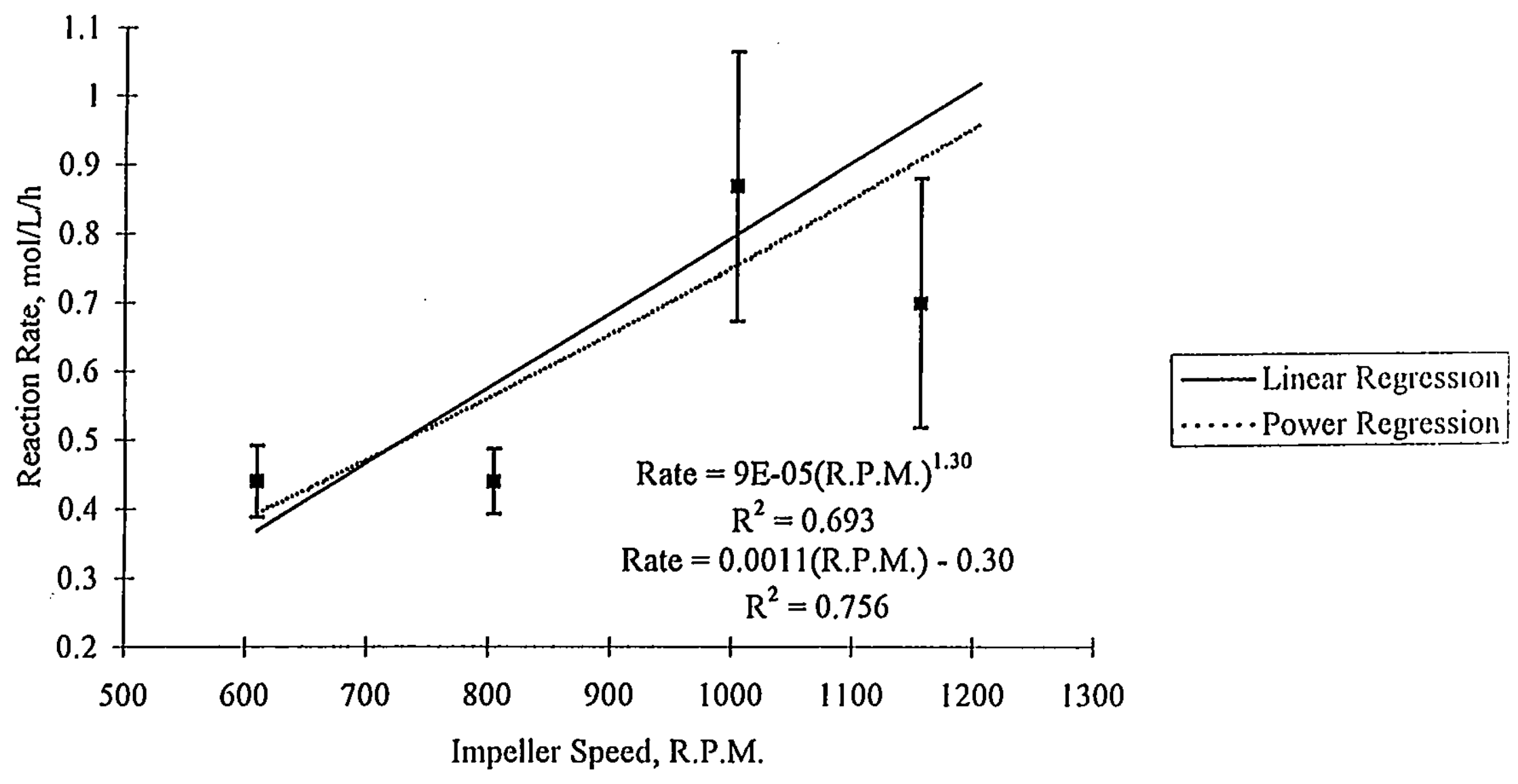

Figure 40: The Effect of Impeller Speed on the MgO Renction Rate 
It was observed during water modeling that in the absence of gas injection. the impeller was abie to draw gas from the frecboard of the reactor at high impeller speeds. This phenomena began at about 700 R.P.M. and rapidly increased above 900 R.P.M.. It is likely that at extremely high power inputs in $\mathrm{MgCl}_{2}$ (c.g. $20 \mathrm{~kW} / \mathrm{m}^{3}$ at $1156 \mathrm{R} . \mathrm{P} . \mathrm{M}$.), the impeller begins to draw in gas from the freeboard. This gas had a very lo: partial pressure of $\mathrm{CO}$ and consisted mainly of $\mathrm{N}_{2}$ (from the purge gas) plus $\mathrm{Cl}_{2}$ and $\mathrm{CO}_{2}$. The mixing of these gases with the new gas being injected into the reactor would have an effect similar to that already shown for direct dilution with $\mathrm{N}_{2}$. Therefore it is concluded that an optimum power input exists somewhere between 12 and $20 \mathrm{~kW} / \mathrm{m}^{3}(1004-1156$ R.P.M.), for this particular reactor.

In order to obtain a power or linear regression it is necessary to exclude Experiment 23 (at 1156 R.P.M. and correspondingly high power input as explained above), the remaining results in Figure 41 have been regressed to give the following correlations:

$$
\begin{array}{ll}
\text { Rate }=0.0011 \text { (R.P.M.) }-0.03, & \mathrm{R}^{2}=0.756 \\
\text { Rate }=9 \times 10^{-5} \text { (R.P.M.) }{ }^{1.30}, & \mathrm{R}^{2}=0.693
\end{array}
$$

\subsection{Effect of Temperature}

Normally, reactions which are diffusion controlled, increase only slowly in rate with increasing temperature, due to higher diffusivities and are typified by an activation energy of about $100 \mathrm{~kJ} / \mathrm{mol}^{26}$. A series of five experiments (10-14) were conducted at temperatures between 743 and $908^{\circ} \mathrm{C}$, at an average of 1005 R.P.M., and $3699 \mathrm{~mL} / \mathrm{min}$ (at S.T.P.) of a $1 / 1$ mixture of $\mathrm{CO}$ and $\mathrm{Cl}_{2}$.

The temperature range was constrained by the freezing point $\left(714^{\circ} \mathrm{C}^{24}\right)$ and boiling point $\left(1318^{\circ} \mathrm{C}^{33}\right.$ ) of the $\mathrm{MgCl}_{2}$. The practical range was further restricted by the necessity to maintain some degree of superheat and the maintain a very low partial pressure of $\mathrm{MgCl}_{2}$ 
to prevent excessive evaporation (the vapour pressure of $\mathrm{MgCl}$ incieases rapidly above 900 "C. reaching 10 Torr at $\left.934^{\text {" }} \mathrm{C}^{2<}\right)$.

The results of these 5 experiments are shown in Figure 41 and have been summarized by a second order polynomial regression:

$$
\text { Rate }=-4.293 \times 10^{-5} \mathrm{~T}^{2}+0.097 \mathrm{~T}-53.7 . \mathrm{R}^{2}=0.955
$$

Figure 41 indicates that an optimum temperature exists, which will maximize the chlorination rate. This was an unexpected result. The optimum temperature is $856.6^{\circ} \mathrm{C}$. based on the $1^{\text {s: }}$ derivative of Equation [50]; however, given the uncertainty in the data and the few data points, the only firm conclusion which can be made. is that the reaction rate reaches a maximum at some temperature between 824 and $908^{\circ} \mathrm{C}$.

The evidence supporting the increase in gas solubility in liquid $\mathrm{MgCl}_{2}$ is not extensive ${ }^{20}$. If the solubility of the gases (particularly $\mathrm{CO}$ ) decreases in the liquid $\mathrm{MgCl}_{2}$ at higher ten:peratures (as is the case with most liquids), then the increase in the diffusivity at elevated temperature, will be off set by a corresponding decrease in the mass transfer driving force and could easily explain a decrease in the overall reaction rate at very high temperatures.

A regression was made of the reaction rates (between $743^{\circ} \mathrm{C}$ and $824^{\circ} \mathrm{C}$ ) with the inverse of the absolute temperature in order to obtain the activation energy using Arrhenius's equation as indicated below:

$$
\text { Rate }=7491 \mathrm{e}^{(-80380 /(\mathrm{R}))}, \quad \mathrm{R}^{2}=0.999
$$

Equation [51] indicates that Reaction (14) (the chlorination reaction), had an activation energy of $80 \mathrm{~kJ} / \mathrm{mol}$, with a $95 \%$ confidence interval of $+/-30 \%$. This magnitude of activation energy is typical of a diffusion controlled reaction, as mentioned previously. 


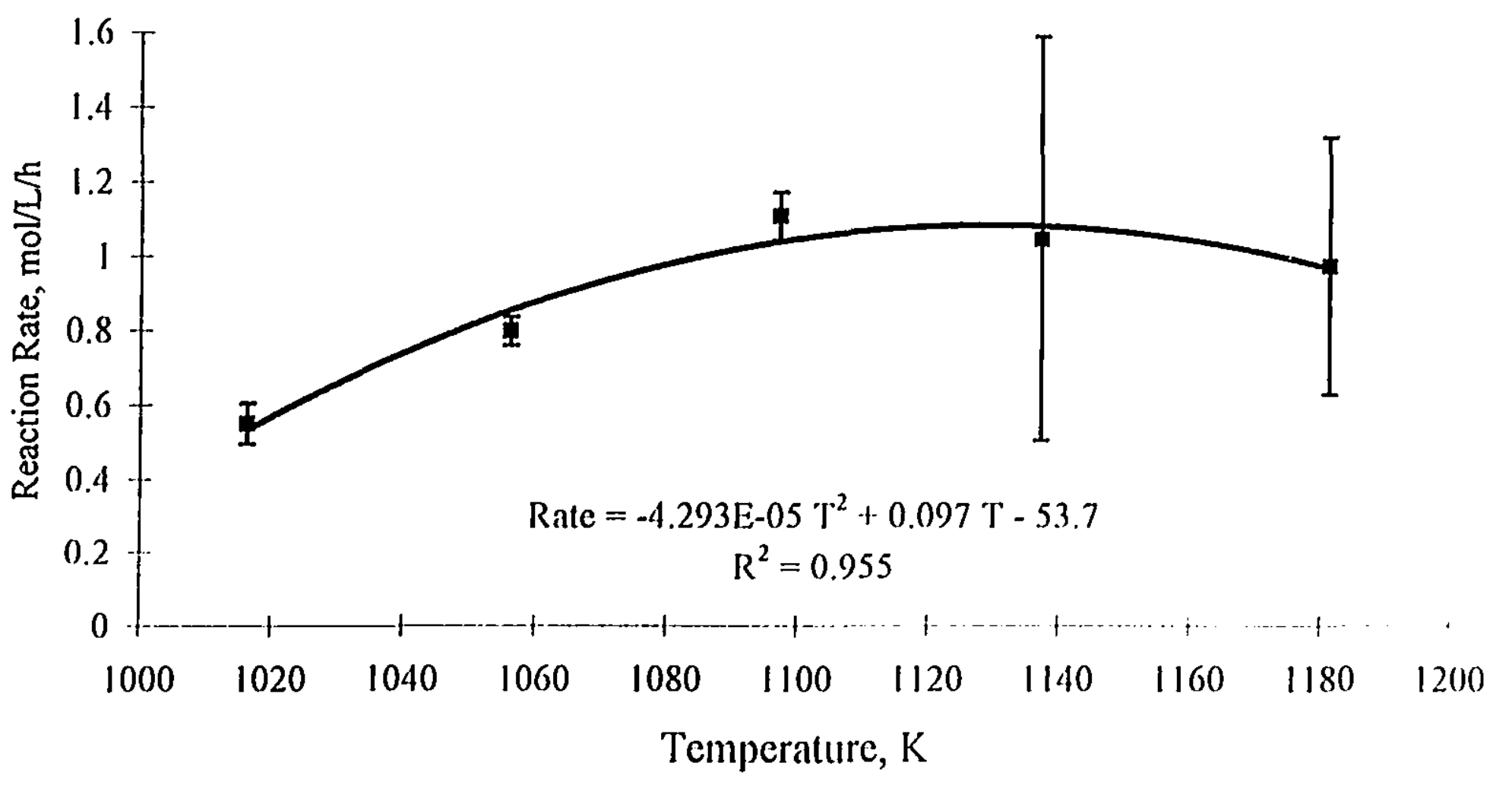

Figure 41: The Effect of Increasing Temperature on the MgO Reaction Rate 


\subsection{Effect of Iron}

Iron has been used as a catalyst in another similar chlorination process. as discussed in Section 2.1.2.1. Two experiments (26 and 27) were conducted where 300 and 600 P.P.M. of iron were added as ferric chioride $\left(\mathrm{FeCl}_{3}\right)$, to the bath of $\mathrm{MgCl}_{2}$, to determine if small amounts of $\mathrm{Fe}$ have a catalytic effect on the chlorination rate. The bath of $\mathrm{MgCl}_{2}$ had a background level of $\mathrm{Fe}$ in the $200-400$ P.P.M. range.

The additional $\mathrm{Fe}$ added in these two experiments resulted in levels of 444 and 560 respectively. Ferric chloride is an extremely volatile chloride with a normal boiling point of $652{ }^{\circ} \mathrm{C}^{25}$. The very high vapour pressure of the $\mathrm{FeCl}_{3}$ resulted in a significant loss of Fe before it could be assimilated into the bath of $\mathrm{MgCl}_{2}$.

The results for Experiments 26 and 27 are compared in Figure 42 with the result of Experiment 22. These experiments were conducted using the (75-106) $\mu \mathrm{m}$ size fraction, at an average of $824^{\circ} \mathrm{C}, 1005$ R.P.M. and $3699 \mathrm{~mL} / \mathrm{min}$, at a $1 / 1$ ratio of $\mathrm{CO}$ and $\mathrm{Cl}_{2}$.

The results shown in Figure $\mathbf{4 2}$ have been correlated by the following equation:

$$
\text { Rate }=0.99-5 \times 10^{-5} \text { (P.P.M. Fe), } \quad R^{2}=0.839
$$

According to Equation [52] the $\mathrm{MgO}$ reaction rate is negatively impacted by the concentration of iron. This should not be surprising, given that the $\mathrm{Fe}$ increases $\mathrm{Cl}_{2}$ mass transfer and it has already been shown that the rate of reaction is controlled by the rate of $\mathrm{CO}$ diffusion. The slight negative correlation may be due to counter diffusion of $\mathrm{FeCl}_{3}$; however, the correlation between $\mathrm{Fe}$ and reaction rate was not statistically significant and thus no firm conclusion was drawn. 


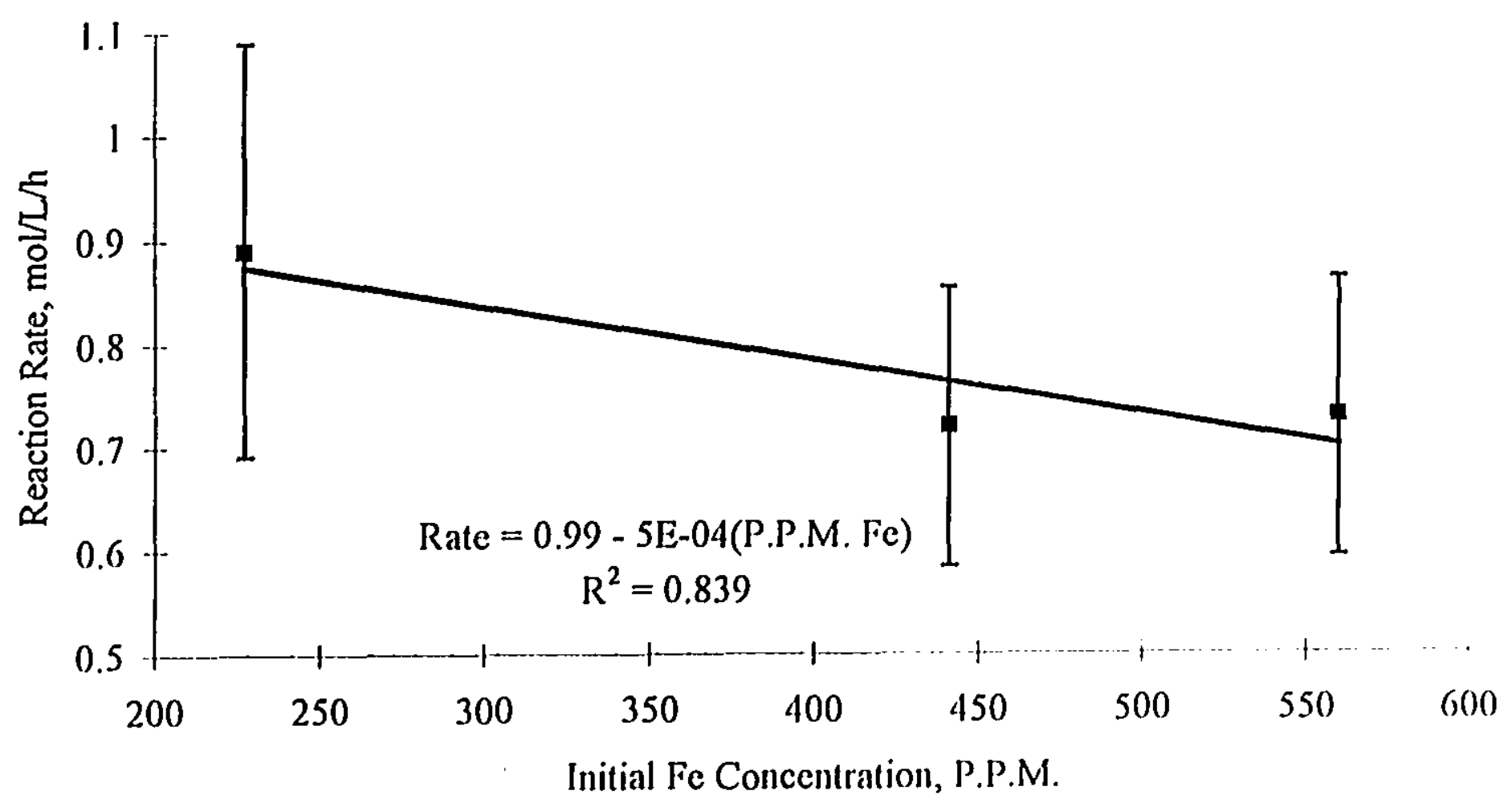

Figure 42: 'The Effect of Iron on the MgO Reaction Rate 


\subsection{Overall Correlation}

It was decided to summarize as many of the results as possible in the form of an overall correlation. using multiple regression and those results in the following ranges:

1) temperature $=\$ 20^{\circ} \mathrm{C}+1-5^{\circ} \mathrm{C}$.

2) impeller speed $=609$ to 1006 R.P.M. $\left(10.5-15.6 \mathrm{~kW} / \mathrm{m}^{3}\right)$.

3) total gas flows (including $\mathrm{N}_{2}$ ) from 941 to $6522 \mathrm{~mL} / \mathrm{min}\left(0.3 \mathrm{~cm} / \mathrm{s}>\mathrm{v}_{\mathrm{s}}<2.2 \mathrm{~cm} / \mathrm{s}\right.$ ).

4) using all particle sizes from 53 to $300 \mu \mathrm{m}$. and

5) $0.67>\mathrm{CO} / \mathrm{Cl}_{2}<1.05$.

25 experiments were regressed: $1,3-9,13,15-22,24-30$. and 33 . It was necessany to restrict the ranges. due to the strong curvature in some of the data (e.g. relationship with $\mathrm{P}_{\mathrm{CO}}\left(\mathrm{P}_{\mathrm{C}_{2}}\right)$ and this curvature can not be modeled using either a linear or power type regression. The power regression is the model of choice, because it usually provides the greatest level of physical significance.

The 25 experiments were correlated against the following independant variables:

1) total gas flow rate at S.T.P. (Q)

2) ratio of $\mathrm{CO} / \mathrm{Cl}_{2}$.

3) partial pressure of carbon monoxide $\left(\mathrm{P}_{\mathrm{co}}\right)$.

4) impeller speed (N),

5) average $\mathrm{MgCO}_{3}$ particle size $\left(d_{\mathrm{p}}\right)$.

6) initial melt height to tank diameter $(\mathrm{H} / \mathrm{T})$ ratio,

7) initial $\mathrm{MgO}$ content ( $\mathrm{wt} . \% \mathrm{MgO}$ ),

8) amount of $\mathrm{MgCO}_{3}$ fed, and

9) the initial $\mathrm{Fe}$ content.

A multiple non-linear (power) regression was performed using Excel Version 7.0, by regressing the logarithm of the reaction rate, against the logarithm of the above variables. 
In the initial regression. only those variables which were found to be signiticant at the $90 \%$ level using the $P$ value outputted by the sottware, were retained for further analysis.

Those parameters found to be significant included:

1) $\mathrm{N}\left(\mathrm{s}^{-1}\right)$.

2) $Q_{t}(\mathrm{~L} / \mathrm{min}$. $)$.

3) $\mathrm{P}_{\mathrm{co}}(\mathrm{atm})$, and

4) $\mathrm{MgO}(\mathrm{wt} . \%)$.

The four remaining parameters were re-regressed and only those significant at the $95 \%$ level were kept. This included all four parameters. The results of this are given below:

$$
\text { Rate }=0.0166 \mathrm{~N}^{1.18} \mathrm{Q}_{\mathrm{t}}^{0.56}\left(\mathrm{P}_{\mathrm{CO}}\right)^{1.13} \mathrm{MgO}^{0.48}, \quad \mathrm{R}^{2}=0.7 \mathrm{S4}
$$

The $95 \%$ confidence intervals for the exponents are as follows:

$\begin{array}{llll} & & \text { low } & \text { high } \\ \text { 1) } & \mathrm{N} & 0.25 & 2.11 \\ \text { 2) } & \mathrm{Q}_{\mathrm{i}} & 0.34 & 0.78 \\ \text { 3) } & \mathrm{P}_{\mathrm{co}} & 0.82 & 1.45 \\ \text { 4) } & \mathrm{MgO} & 0.03 & 0.93\end{array}$

The experimental results are plotted as a function of the regression parameter $\left(\mathrm{N}^{1.18} \mathrm{Q}^{0.56}\left(\mathrm{P}_{\mathrm{CO}}\right)^{1.13} \mathrm{MgO}^{0.48}\right)$ in Figure 43.

When Equation [53] was used in conjunction with Equation [51] it was possible to estimate the reaction rate at temperanures between 743 and $824^{\circ} \mathrm{C}$.

Equation [53] predicted the experimental rates to within + or $-44 \%$. with $95 \%$ confidence and while this is not as good a correlation as was desired. it represents the only information in the public domain regarding this reaction conducted in a stirred tank reactor. 


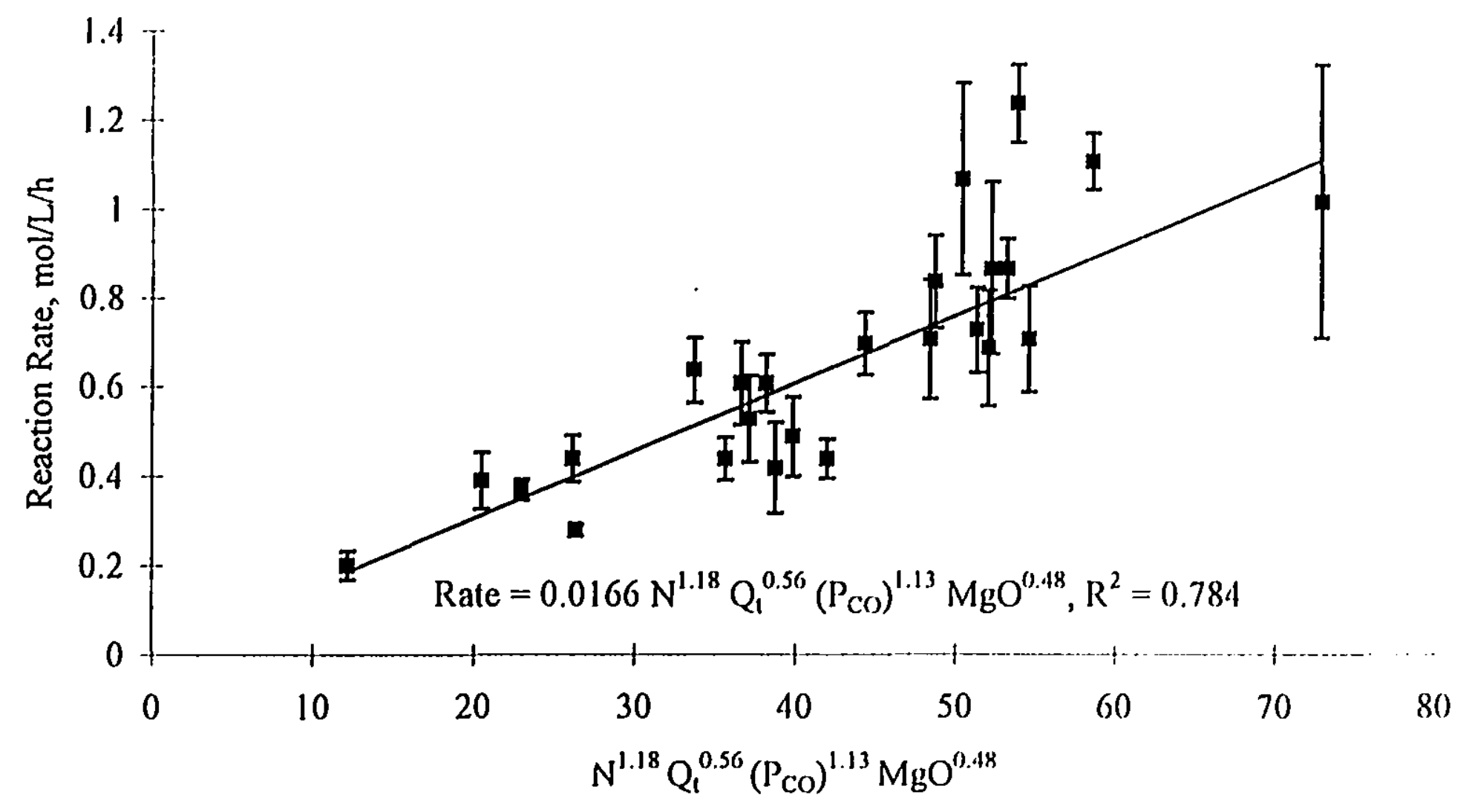

Figure 43: The Effect of Impeller Speed, Gas Injection, $P_{c o}$ and Initial $\mathrm{MgO}_{\mathrm{g}}$ on the Reaction Rate 
The weak correlation of the reaction rate whth the initial yuantity of 19 (g) and the independence of the reaction rate with the residual quantity of .Mg( after time zero. suggested that the initial quantity of MgO was substituting for an unmeasured parameter. It is proposed that the unmeasured parameter is an impurity associated with the Mg() (essentially the source of all the impurities in the system). The initial concentration of this impurity. would have increased with increasing $\mathrm{MgO}$ content and must have had a positive impact on the reaction rate. If this hypothetical catalyst exists. this could have a dramatic impact on the economics of a chlorination process using a stirred tank reactor.

Given that the reaction rate is determined by the mass transfer of $\mathrm{CO}$ into the $\mathrm{MgCl}$.. it is further assumed that the hypothetical impurity enhances the mass transfer of CO. by increasing its solubility in the $\mathrm{MgCl}_{2}$ and thereby increases the rate of the chlorination reaction. Nickel is an obvious candidate. based on its proven ability to complex with $\mathrm{CO}$. It is therefore recommended that if these experiments are ever repeated. reagent grade $\mathrm{MgO}$ should be used in conjunction with a variety of motals (including nickel). to determine which metal if any. has a catalytic effect on the reaction rate.

An equation using $P_{2} / N_{1}\left(\mathrm{~kW} / \mathrm{m}^{3}\right)$ and $v_{3}(\mathrm{~cm} / \mathrm{s})$ is of more use than Equation [53] in the scale-up of a chlorination system. based upon a stirred tank reactor. Taking a power number of 2.76 (from Section 6.1) and using Equations [24] and [36]. it was possible to calculate the $P_{k} /$ for each combination of gas injection rate and impeller speed in these experiments. When this was done and the data was re-regressed. the following equation was obtained:

$$
\text { Rate }=0.321\left(\mathrm{P}_{\mathrm{g}} \mathrm{V}_{1}\right)^{0.35}\left(\mathrm{v}_{\mathrm{s}}\right)^{0.04}\left(\mathrm{P}_{\mathrm{CO}}\right)^{1.14}(\mathrm{MgO})^{0.40},+1-44 \% . \mathrm{R}^{2}=0.7 \mathrm{Sl}
$$

The $95 \%$ confidence intervals for the various exponents are:

$\begin{array}{llll} & & \text { low } & \text { high } \\ 1) & \left(\mathrm{P}_{\mathrm{s}} \mathrm{N}_{\mathrm{l}}\right) & 0.07 & 0.64 \\ 2) & \left(v_{\mathrm{s}}\right. & 0.40 & 0.5 \mathrm{~s} \\ 3) & \left(\mathrm{P}_{\mathrm{co}}\right) & 0.52 & 1.46 \\ 4) & (\mathrm{MgO}) & 0.04 & 0.92\end{array}$


The exponents of $\left(\mathrm{P}_{0} \mathrm{~N}_{1}\right)$ in Equation [54] were compared with those in the literafure. (see Section 3.2); however, the literature values varied gleatly and the possiule range of values as indicated by the $95 \%$ confidence intervals given above. were too large to make a comparison meaningful. 


\section{Chapter 8 Discussion}

The results presented in Chapter 7 can be used to design geometrically similar industrial scale. continuous reactors. The ultimate limitation on the size of the reactor is probably the length of shaft which can be practically produced from commercial grades of graphite, based on available sizes and mechanical properties. The maximum practical size for a unit cell, is about $1 \mathrm{~m}$ in depth (and width). given that the maximum length of commercial graphite available to produce impeller shafts, is about $6^{\circ}(1.83 \mathrm{~m})^{78}$.

A full scale plant based on this technology, would require either many small reactors, or more practically, a series of large reactors, each with many rotary injectors. A square reactor can be produced based on a cellular approach, as shown in Figure 44. The reactor would be fed with calcined magnesite $(\mathrm{MgO})$ to remove the thermal burden from the reactor and prevent the introduction of excess $\mathrm{CO}_{2}$ gas into the reactor. Feeding would be through graphite tubes and rectangular graphite electrodes would be used as baffles online and to make up for heat lost during down time. A multiple of 3 electrodes is required to use 3-phase AC heating. A refractory lined steel shell would be used to contain the magnesium chloride bath. The type of refractory used would have to be nptimized to prevent chlorination of the refractory or contamination of the $\mathrm{MgCl}_{2}$. The shell would probably require cathodic protection to prevent corrosion by chlorine gas.

In Figure 44, each cell would be assumed to act as a single CSTR. There is no loss in efficiency or conversion using the reactor design shown in Figure 44. given that the reaction has been shown to be independant of the $\mathrm{MgO}$ concentration (cascading the reactors is not required). Gas utilization efficiencies and reaction rates will be the same at $0.5 \% \mathrm{MgO}$ as at $5 \% \mathrm{MgO}$ (as shown in Figure 34) and the reactor can therefore operate at a steady state value of $0.5 \% \mathrm{MgO}$ or less. A small polishing section. operating with less $\mathrm{MgO}$ (as little as $0.1 \%$ ) may be required depending on the type of electrolysis cell chosen (see Table 3 and Figure 3). The polishing section would also serve to volatilize unwanted impurities such as $\mathrm{Fe}$. 


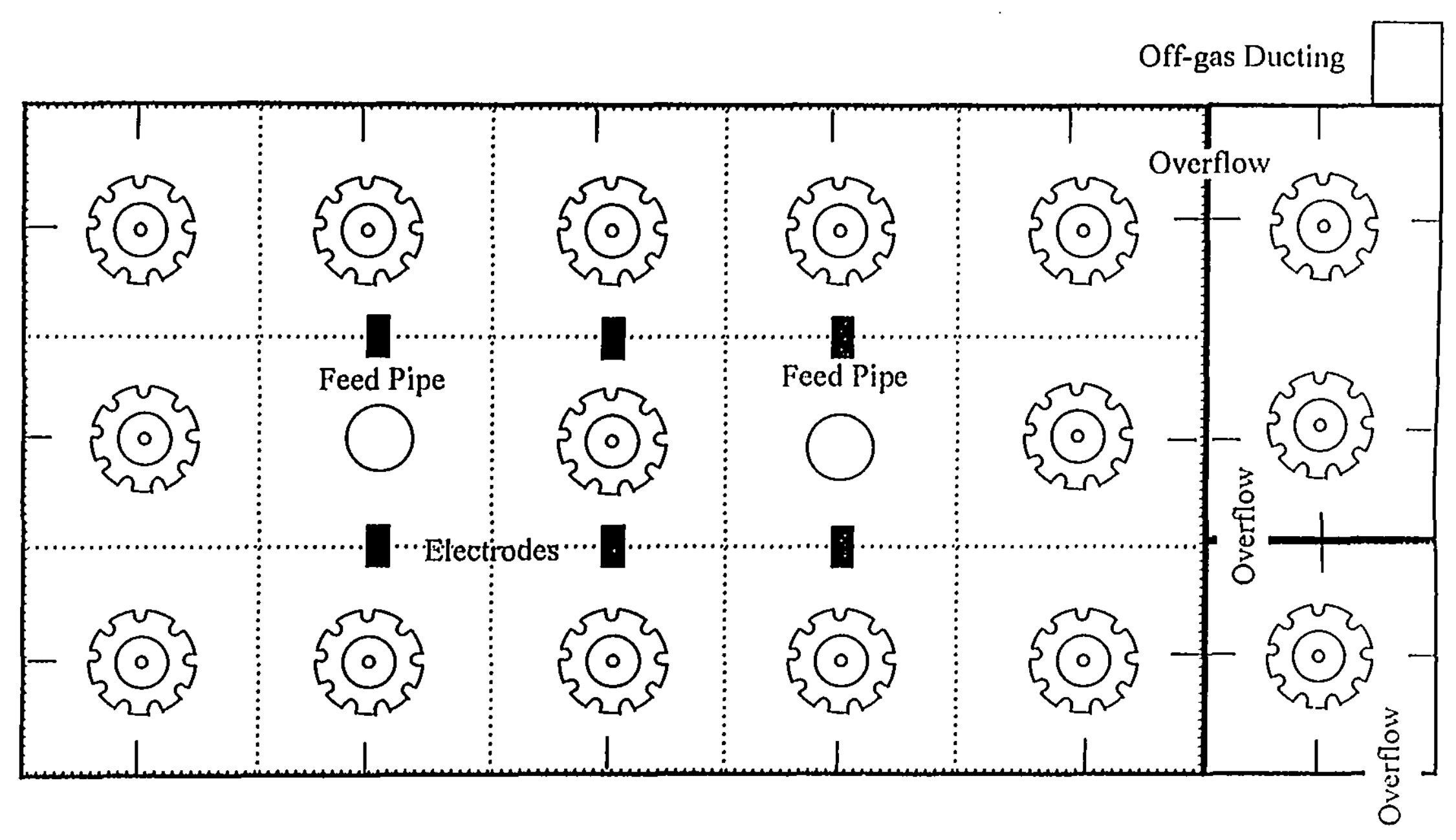

Figure 44: Conceptual Design of An Industrial Chlorinator 
The impact of the dependancy of the reaction rate on the initial $\mathrm{MgO}$. must be further investigated in order to accurately predict behavior on scale-up. It will be possible to optimize the reaction rate, if the impurity responsible for this behavior is identified; however, for the purposes of discussion. Equation [54] will be evaluated using the average initial $\mathrm{MgO}$ (4.02\%) of the 25 experiments used to derive the equation:

$$
\text { Rate }=0.609\left(P_{s} / V_{1}\right)^{0.35}\left(v_{s}\right)^{0.64}\left(P_{C O}\right)^{1.14}
$$

Care must be taken in applying Equation [55]. since it is bounded in several ways. The possible combinations of gas injection rate and power per unit volume are restricted by flooding at low power and surface aeration at high power. The rate is also restricted by gas efficiency, which obviously can not exceed $100 \%$ for either $\mathrm{CO}$ or $\mathrm{Cl}_{2}$ (i.e. very high $\mathrm{P}_{\mathrm{k}} / \mathrm{V}_{1}$ and $\mathrm{v}_{\mathrm{s}}$ can not increase the gas reaction efficiency to more than $100 \%$ ).

If the goal of the scale-up is to achieve a constant volumetric reaction rate, then obviously the simplest way of achieving this is to maintain a constant $P_{E} / V_{1}, v_{s}$, and $P_{c o}$ (as indicated by Equation [55]). It is also logical to assume that the same volume of gas will be injected per liquid volume $\left(Q / V_{1}\right)$. Unfortunately, the surface area of the vessel increases to $\mathrm{T}^{2}$, while volume increases to $\mathrm{T}^{3}$, so $\mathrm{v}_{3}$ increases with a linear scale-up. Therefore, to achieve the same reaction efficiency, $P_{k} / V_{1}$ must decrease by reducing the impeller speed (it is normal for $P_{5} / V_{1}$ to decrease on scale-up); however, it is important to respect the limits of flooding (Equation [26]) and to suspend the largest $(300 \mu \mathrm{m})$ particles (Equation [29]).

The simplest way to deal with the actual complexity of scale-up is to use a commercial software package, such as Tk Solver Version 2.0, to simultaneously solve the appropriate equations presented in Chapters 3.0, 6.0, 7.0 and 8.0. Using Tk Solver, with $T=1.0 \mathrm{~m}$, Temperature $=856.6^{\circ} \mathrm{C}$, and $\mathrm{CO} / \mathrm{Cl}_{2}=1.24$ and using the design shown in Figure 44,9 chlorinators could produce 20,000 mtpy of magnesium, at a reaction rate of $1.0 \mathrm{~mol} / \mathrm{L} / \mathrm{h}$ and $90 \%$ chlorine reaction efficiency (see Appendix $C$ for details). 


\section{Chapter 9 Conclusions}

\subsection{Conclusions - Experimental Part I}

In MOLTEN $\mathrm{MgCl}_{2}$ the impeller power number was found to be $2.76 \pm 10 \%$ at impeller Reynolds numbers above 70,000 .

Gassed impeller power in $\mathrm{MOLTEN} \mathrm{MgCl}_{2}$ was correlated by the following equations:

$$
\begin{array}{llll}
\mathrm{P}_{\mathrm{R}} / \mathrm{P}_{\mathrm{o}}= & 0.452\left(\mathrm{Q} / \mathrm{ND}^{3}\right)^{-0.22} & \mathrm{R}^{2}=0.885 & {[35]} \\
\mathrm{P}_{\mathrm{k}} / \mathrm{P}_{\mathrm{o}}= & 0.922-1.444\left(\mathrm{Q} / \mathrm{ND}^{3}\right) & \mathrm{R}^{2}=0.893 & {[36]}
\end{array}
$$

The exponent in Equation [35] will be influenced by the exact impeller/tank geometry used; however, the magnitude of the exponent in Equation [35] does fall within the published range $\left(-0.22\right.$ to $\left.-0.38^{60.68}\right)$ for flat six blade turbines.

The gas dispersion pattern was found to be in the gross recirculation bubble regime.

\subsection{Conclusions - Experimental Part II}

Magnesite can be chlorinated in a STIRRED slurry reactor, using chlorine and carbon monoxide, under conditions, which can be reproduced on the industrial scale.

The chlorination rate of the $\mathrm{MgO}$ formed from magnesite was found to be independant of the $\mathrm{MgO}$ concentration present in the reactor (or Zero order with respect to the concentration of $\mathrm{MgO}$ ). 
The reaction rate was found to increase with increasing gas injection rate according to the following empirical correlations:

$$
\begin{array}{ll}
\text { Rate }=0.33+1 \times 10^{-4}\left(\mathrm{Q}_{1}\right) . & \left(\mathrm{mol} / \mathrm{L} / \mathrm{h} \text { or } \mathrm{kgmol} / \mathrm{m}^{3} / \mathrm{h}\right) . \mathrm{R}^{2}=0.760[42] \\
\text { Rate }=5.3 \times 10^{-3}\left(\mathrm{Q}_{1}\right)^{0.63} . & \left(\mathrm{mol} / \mathrm{L} / \mathrm{h} \text { or } \mathrm{kgmol} / \mathrm{m}^{3} / \mathrm{h}\right) . \mathrm{R}^{2}=0.866[43]
\end{array}
$$

The reaction rate was found to be independant of the $\mathrm{MgO}$ particle size.

The chlorination rate increased with increasing levels of $\mathrm{CO}$ according to the follrwing empirical correlation:

$$
\text { Rate = -2.1 }\left(\mathrm{P}_{\mathrm{co}} / \mathrm{P}_{\mathrm{Cl}_{2}}\right)^{2}+5.2\left(\mathrm{P}_{\mathrm{co}} / \mathrm{P}_{\mathrm{Cl}_{2}}\right)-2.13 \cdot \mathrm{R}^{2}=0.897
$$

The optimum $\mathrm{CO} / \mathrm{Cl}_{2}$ ratio was found to be between 1.02 and 1.47 and was estimated to be 1.24 from Equation [44].

The rate limiting step in the chlorination of magnesite in a slurry reactor was found to be $\mathrm{CO}$ mass transfer from the gas to the liquid phase.

The addition of an inert gas such as $\mathrm{N}_{2}$. was found to decrease the rate of the reaction as indicated below:

$$
\begin{array}{ll}
\text { Rate }=0.943-0.011\left(\% \mathrm{~N}_{2}\right) . & R^{2}=0.942 \\
R_{d} / R_{o}=0.988-0.0067\left(\% N_{2}\right) . & R^{2}=0.911
\end{array}
$$

Impeller speed was found to increase the rate of the chlorination reaction up to a maximum located between 12 and $20 \mathrm{~kW} / \mathrm{m}^{3}$, after which the rate was found to decrease (probably due to surface aeration). Between 600-1004 R.P.M. the following empirical correlations were obtained:

$$
\begin{array}{ll}
\text { Rate }=0.0011 \text { (R.P.M.) }-0.03, & \mathrm{R}^{2}=0.756 \\
\text { Rate } \left.=9 \times 10^{-5} \text { (R.P.M. }\right)^{130}, & \mathrm{R}^{2}=0.693
\end{array}
$$


The reaction rate was found to increase at higher temperatures. until a maximum located between $\$ 24$ and $908^{\circ} \mathrm{C}$ was reached. The maximum rate was estimated to be at $856.6^{\circ} \mathrm{C}$ from the following empirical correlation:

$$
\text { Rate }=-4.293 \times 10^{-5} \mathrm{~T}^{2}+0.097 \mathrm{~T}-53.7 . \mathrm{R}^{2}=0.955
$$

The reaction rate was correlated using an Arrhenius relationship between 743 and $824^{\circ} \mathrm{C}$ :

$$
\text { Rate }=7491 \mathrm{e}^{(-80380 /(\mathrm{R} T)}, \quad \mathrm{R}^{2}=0.999
$$

with an activation energy of $80 \mathrm{~kJ} / \mathrm{mol}$, which is typical of a diffusion controlled reaction.

Iron was found to have no significant effect on the reaction rate at levels up to 560 P.P.M. Fe.

An overall correlation was obtained which related reaction rate with impeller power. superficial gas velocity and the partial pressure of $\mathrm{CO}$ :

$$
\text { Rate }=0.609\left(P_{s} N_{1}\right)^{0.35}\left(v_{s}\right)^{0.64}\left(P_{c o}\right)^{t .14}
$$

Using the overall correlation it was estimated that 9 chlorination reactors each containing 16 impellers ( $0.48 \mathrm{~m}$ in diameter) would be sufficient to produce $20,000 \mathrm{mtpy}$ of magnesium. 


\section{Chapter 10 Recommendations for Future Work}

In order to obtain more accurate mixing power and power number data. an impeller of at least $6 "$ or $0.15 \mathrm{~m}$, should be used in any future work.

Gas hold-up was not adequately determined during these experiments and should be further investigated using a larger reactor with better access for measurement.

It was hypothesized that an impurity was present in the $\mathrm{MgO}$. which positively affected the rate of $\mathrm{CO}$ mass transfer. Experiments using pure $\mathrm{MgCl}_{2}$, reagent grade $\mathrm{MgO}$ and various potential catalytic metals (e.g. Ni), should be conducted to verify this hypothesis and quantify the effect.

To eliminate the effect of segregation within a sample, whole pin tube samples should be analysed.

The homogeneity of the $\mathrm{MgO}$ suspended within the reactor should be verified during any future test program and multiple samples should probably be used to obtain a good average assay from which the reaction rate can be computed.

In order to minimize the uncertainty in the calculated reaction rates. sampling frequency should be increased for those experiments expected to react quickly.

A randomized statistically designed experimental plan (e.g. Box-Behnken ${ }^{85}$ ) should be used to obtain the most statistically significant results in the least number of experiments. 


\section{Appendix A - List of Suppliers}

\begin{tabular}{|c|c|c|c|c|}
\hline Supplier & Item & Address & Phone & $\Gamma_{\mathrm{ax}}$ \\
\hline A.P. Green & G-26, G-28 Fireclay Brick & & $514.493-4.400$ & \\
\hline Anachemia & $\mathrm{FeCl}_{3}$ & $5002^{\text {rd }}$ Ave., St. Pierre, Q.C. & $514-489-5711$ & \\
\hline Baymag & Magnesite & 800, 10655 South Port Rd., S.W., Calgary, Alberta & $403-271-9400$ & \\
\hline Canadian Thermix & EF 444 Crucibles & 20 Industrial Parkway N, Unit $2 A$, Aurora, ON & $416.841-6633$ & \\
\hline Cole Parmier & Mac I4 Data Logger & 7425 North Oak Park Ave., Niles, 11. & $800-323-4340$ & $708 \cdot 549-1700$ \\
\hline M.B.S. & Seal Master NP16 C Bearings & 500 rue Hodgc, Montreal, Q.C. & $514-748.8383$ & $514.748-1575$ \\
\hline M.B.S. & TL $18, \mathrm{H} 200$, timing pulley & 500 rue Hodge, Montreal, Q.C. & $514-748-8383$ & $514 \cdot 748 \cdot 1575$ \\
\hline M.B.S. & TL $36, \mathrm{H} 200$, timing pulley & 500 rue Hodge, Montreal, Q.C. & $514-748-8383$ & $514-748-1575$ \\
\hline M.B.S. & $2 ", H 66,11200$, timing belt & 500 rue Hodge, Montreal, Q.C. & $514-748-8383$ & $514-748 \cdot 1575$ \\
\hline M.B.S. & SK, l" Bushing, QD & 500 rue Hodge, Montreal, Q.C. & $514-748-8383$ & $514-748 \cdot 1575$ \\
\hline M.B.S. & 1215, 7/8", Bushing, QD & 500 rue Hodge, Montreal, Q.C. & $514-748-8383$ & $514-748-1575$ \\
\hline M.E.G.S. & H.P. Chlorine & 5601 Chemin. St. Francois, St. Laurent Q.C. & $514-956-7503$ & $514.956-750.1$ \\
\hline M.P.B. & Quartz Ladles & I725 N. Service Rd., T.C., Dorval, Q.C. & 514.694 .8751 & $51.4 .695-7.492$ \\
\hline Medigaz & $\begin{array}{c}\text { Carbon Monoxide, Type K, C.P. } \\
\text { Grade }\end{array}$ & 4830 ruc Coursers, Si. Laurent, Q.C. & $514-337-3854$ & $51.4-337-3295$ \\
\hline Medigaz & Liquid Nitrogen, 225 P.S.I. & 4830 rue Coursers, St. iaurent, Q.C. & $514-337-3854$ & $514-337-3295$ \\
\hline Omega & CN 9000 Temp. Control. & One Omega Dr., Box 4047, Stamford, Connecticut & $800-826.6342$ & \\
\hline Omega & D.P.F.60 Rate Meter & One Omega Dr., Box 4047, Stamford, Connecticut & $800-826-6342$ & \\
\hline R.D.C. Controle & $\begin{array}{l}\text { Type K Thermocouples, } 1 / 8 \text { " X } \\
24 \text { " SS Sheath }\end{array}$ & 6I Boul. de la Seigneurie, Blainville, Q.C. & 514.434 .0216 & 514.434 .0219 \\
\hline Raycon, Les Controles & $\begin{array}{c}\text { Deublin Rotary Union, Model } \\
\text { H1102 } 070081\end{array}$ & 2890 Sabourin, St. J.aurent, Q.C. & $514-334-0931$ & \\
\hline S.T.A.S. & Drive Shaft and Coupling & 1846 rue Outarde, Chicoutimi, Q.C. & $418-696-1951$ & $418-696-1951$ \\
\hline Speer Carbon & 890-S Graphite & 3200 Sartelon St., St. Laurent, Q.C. & $514-332-9602$ & $514 \cdot 332 \cdot 5232$ \\
\hline UCAR & ATJ Graphite & 123 Eglinton Ave, E., Toronto, On & $416.488-1444$ & $416.488-1937$ \\
\hline UCAR & C-34 Graphite Cement & 123 Eglinton $A v e$, E., Toronto, On & $416.488-1444$ & $416-488-1937$ \\
\hline Williams+Wilson & Fibre Frax Blanket/Board & & 514.939 .1300 & \\
\hline
\end{tabular}




\section{Appendix B - Analysis of the Variance of Experimental Data}

Duplicate start samples were taken prior to beginning each experiment. A laboratory analysis was performed on each. Duplicate assays were also performed on one sample from each test. This duplicate assay was not necessarily performed on a start sample.

Each pair of samples was averaged and the absolute and percentage difference of the two samples from the mean was calculated as shown below:

Sample 1: $5 \% \mathrm{MgO}$. Sample 2: $4 \% \mathrm{MgO}$

Average: $4.5 \% \mathrm{MgO}$. Difference $0.5 \% \mathrm{MgO}$. \% Difference $11.1 \%$

The various assays are given in Table B.1.

Plots were made of the absolute and percentage difference of the duplicate samples (Figure B.1) and duplicate assays (Figure B.2).

Ideally, the errors should be randomly distributed with respect to the average $\mathrm{MgO}$ assay. In Figure B.1, it would appear that both the percentage and absolute error increases at the higher levels of $\mathrm{MgO}$; however, the percentage error is more random. In Figure B.2, it is clear that the percentage error is random. while the absolute error increases at higher levels of $\mathrm{MgO}$. It is therefore concluded that the percentage error is more representative of the actual accuracy of the data and that only the variances in the percentage errors can be used to compare the magnitudes of the sources of variance (sampling + analysis).

The total variance (sampling + analysis) has been calculated to be:

$\mathrm{S}_{\text {todat }}^{2}=128.2=\mathrm{S}_{\text {sampling }}^{2}+\mathrm{S}_{\text {analysis }}^{2}$

and the analysis variance has been calculated to be:

$\mathrm{S}_{\text {analysis }}^{2}=20.7$

therefore:

$S_{\text {sampling }}^{2}=128.7-20.7=107.5$

and:

$S_{\text {sampling }}^{2} / S_{\text {totat }}^{2}=107.5 / 128.2 * 100 \%=84 \%$.

Therefore, approximately $84 \%$ of the total variance in the data is due to sampling and $16 \%$ is due to analysis. The $95 \%$ confidence intervals for the total can be calculated from the degrees of freedom (31) and the total standard deviation:

$S_{\text {lotal }}=(128.7)^{0.5}=11.3 \%$.

From the student $\$$ T distribution at the $95 \%$ confidence level. the limits are:

$+/-2.04 * 11.3 \%=+1-23.1 \%$. 


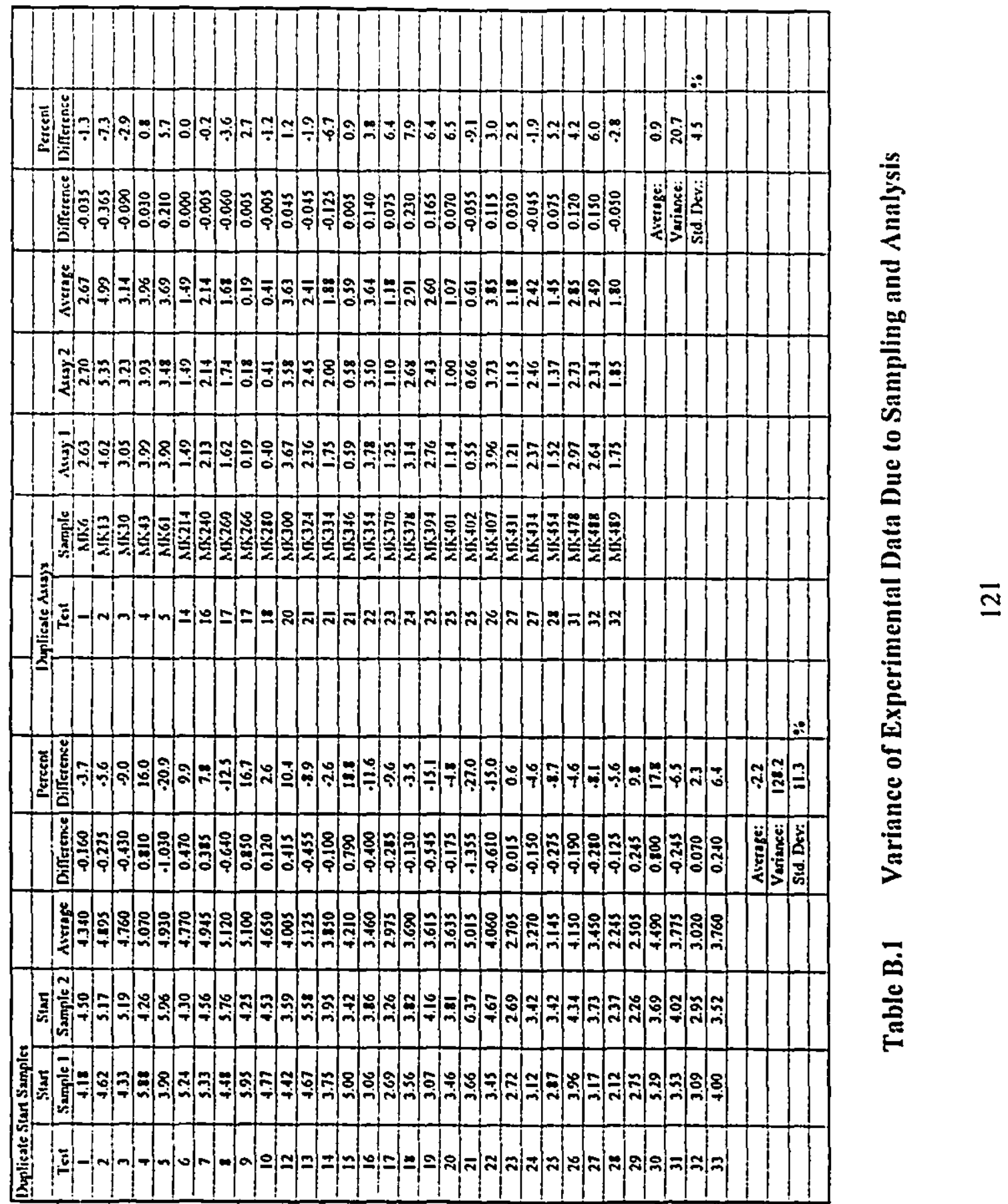




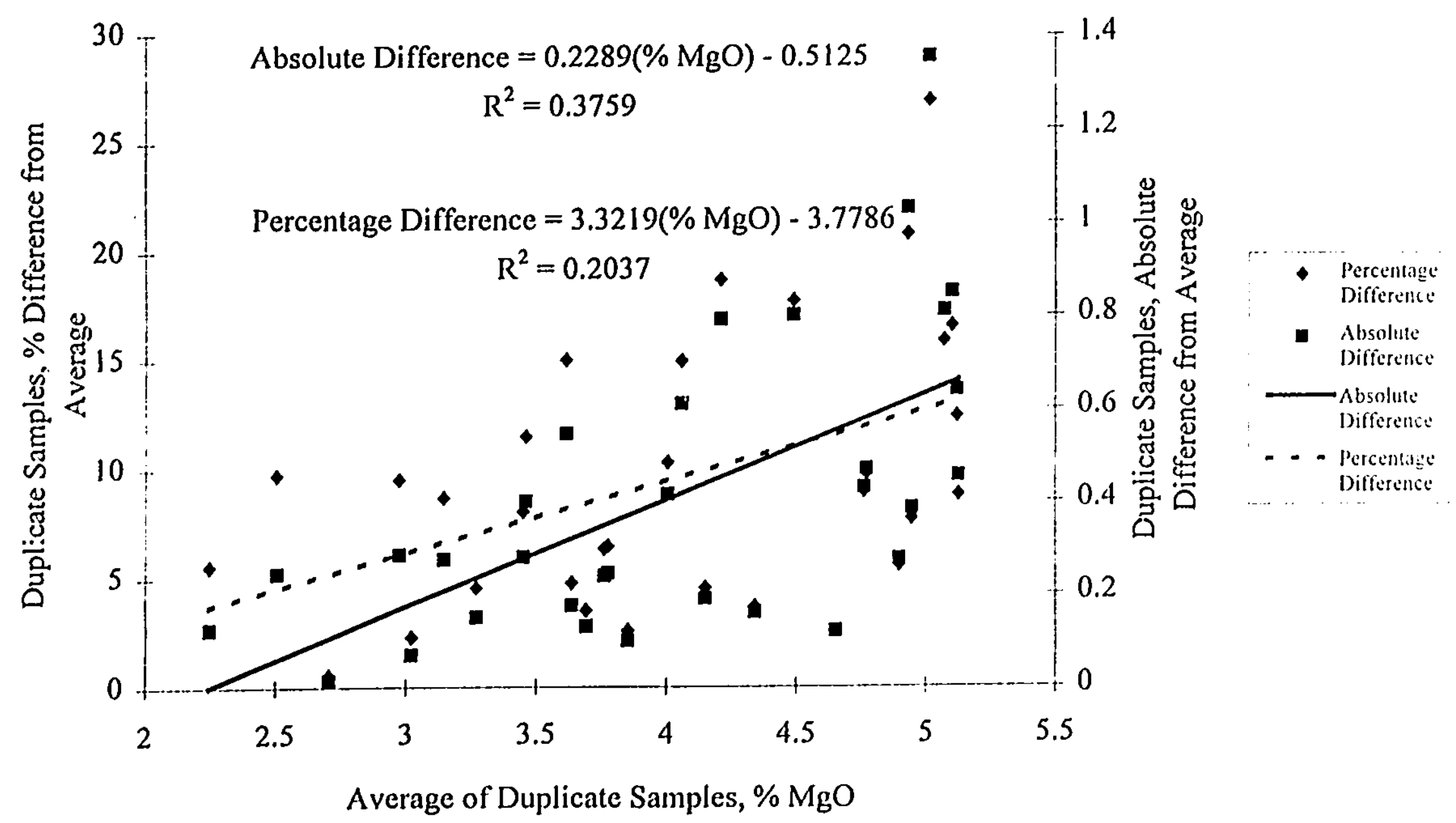

Figure B.1: Variance of Duplicate Samples 


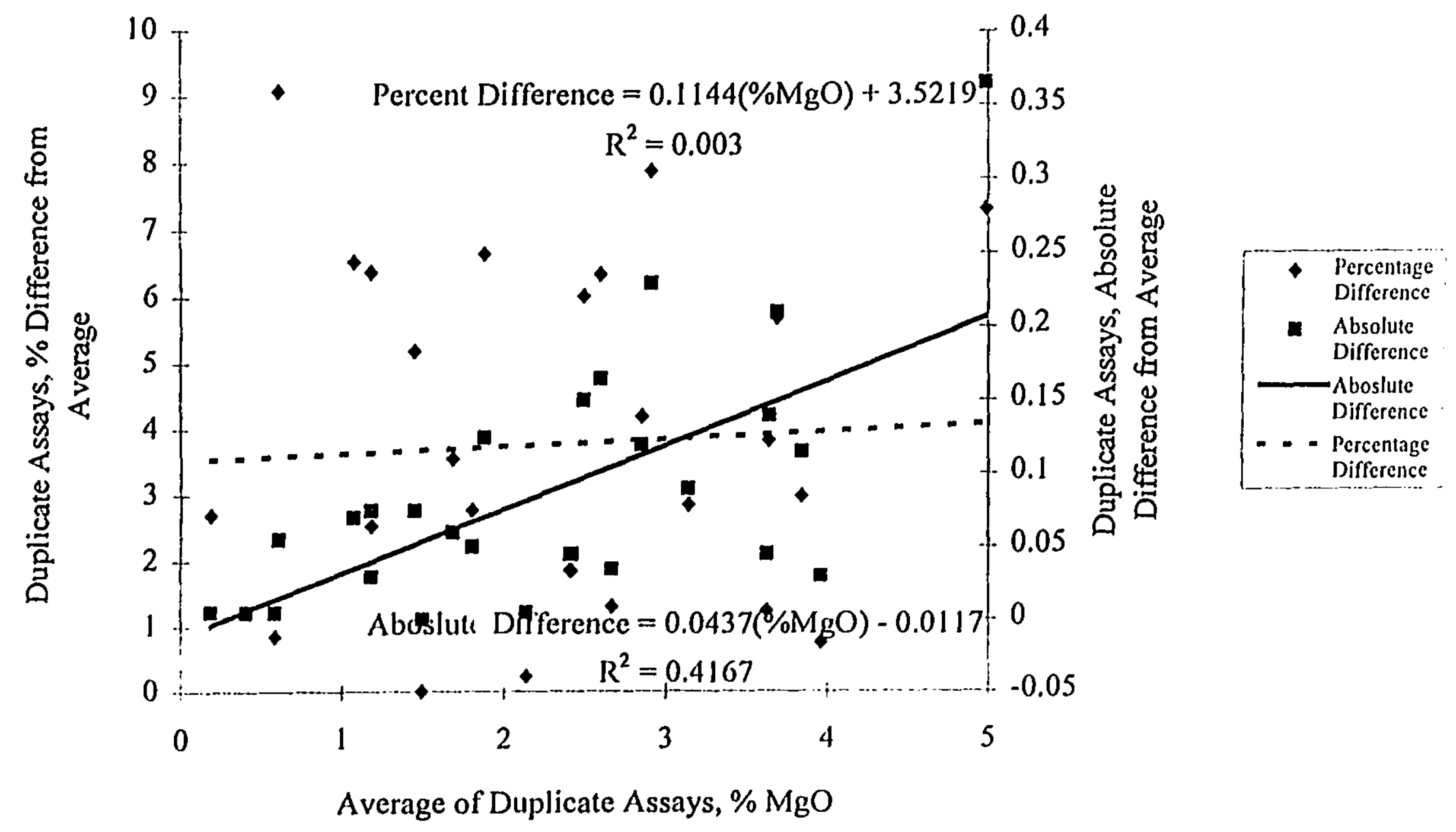

Iigure B.2: Variance of Duplicate Assays 
Appendix C: - Reactor Design Equations

S Rule

$\mathrm{QCO}=\mathrm{QCI} 2 * 1.24$

$Q t=Q C 12+Q C O$

$\mathrm{Q}=\mathrm{Qt} *(\mathrm{Temp}+273.15) / 273.15$

$p=((1.976-0.302 * .001 *(T e m p+273.15)) * 1000) *(1-x / 100)+\lambda / 100 * 1000 * 3.58$

$\mathrm{D}=0.48 * \mathrm{~T}$

$P O=N P * P * N \wedge 3 * D \wedge 5 / 1000$

$\mathrm{Na}=Q / \mathrm{N} / \mathrm{D}^{\wedge} 3$

$\mathrm{Pg} / \mathrm{PO}=(0.922-1.444 *(\mathrm{Na}))$

$v t=T^{\wedge} 3$

$a=T^{\wedge} 2$

$v s=Q / a * 100$

$\mathrm{PV}=\mathrm{Pg} / \mathrm{NI}$

$V I=V t *(1-E)$

$T f=(7491 * \exp (-80380 / 8.3 i 4 /(T \operatorname{emp}+273.15)) /(7491 \star \exp (-80380 / 8.314 /(823+273.15))$

$\mathrm{PCO}=\mathrm{QCO} /(\mathrm{QCO}+\mathrm{QC2} 2 \mathrm{2})$

$R=0.609 *(\mathrm{Pg} / \mathrm{VI}) \wedge 0.35 * v \mathrm{~S}^{\wedge} 0.64 * \mathrm{PCO} 1.14 * \mathrm{Tf}$

Production $=R * V 1 * 24.305 * 24 * 365 * .9 / 1000$

Prodtotal $=\Omega *$ Production $* 13$

MgCO3=Prodtotal $*(40.305+44) / 24.305 / .9$

Eff $=R / 60 / 60 * V 1 /(Q C l 2 / 22.4) * 100$

$u=0.204 * \exp (19361 / 8.314 /($ Temp +273.15$)) / 1000$

$v=\mathrm{u} / \mathrm{p}$

$\mathrm{pl}=(1.976-0.302 / 1000 *($ Temp +273.15$)) * 1000$

$\mathrm{N} j=s * v \wedge 0.1 * d \wedge 0.2 *(\mathrm{~g} *(\mathrm{ps}-\mathrm{pl} / 1000) /(\mathrm{pl} / 1000)) \wedge 0.45 * \mathrm{X} \wedge 0.13 / 0 \wedge 0.85$

$Q / N f 100 d \wedge 3 / D^{\wedge} 3=30 *(D / T) \wedge 3.5 * D / g$ 


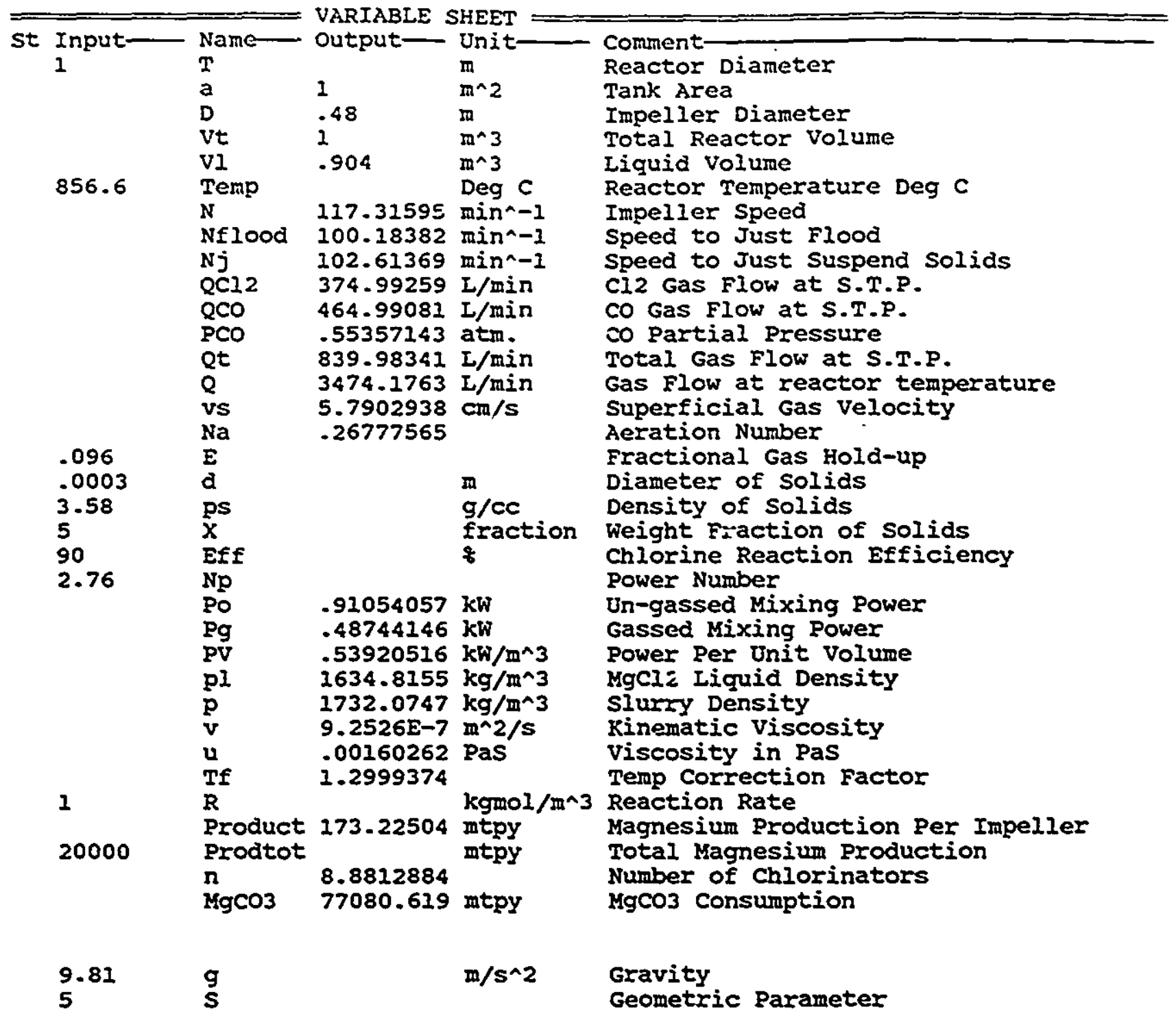




\section{References}

1. G.J. Kipouros and D.R. Sadoway: "The Chemistry and Electrochemistry of Magnesium Production," Advances in Molten Salt Chemistry 6, G. Mamantov

C.B. Mamantov and J. Braunstein, eds.. Elsevier, Amsterdam, 1987, pp. 127-209.

2. L.M. Logerot and J. Moyen: "Magnesium Production Methods-Raw Materials and Availability." Light Metal Age. December, 1982, pp. 27-30.

3. "Primary Magnesium Ingot and Magnesium Alloy Ingot," Dow Chemical Form No. $141-453-82$, U.S.A..

4. Merals Handbook, H.E. Boyer and T.L. Gall, eds., A.S.M., May 1985, U.S.A., pp. 8.11-12.

5. C.R. Hammond: "The Elements," $C R C$ Handbook of Chemistry and Physics. 59th Ed., R.C. Weast and M.J. Astle, eds., CRC Press, Boca Raton, Florida, 1978. pp. B-4-B-66.

6. N. Jarrett: "Advances in the Smelting of Magnesium," Metallurgical Treatsies, J.K. Tien and J.F. Elliott, ecis., Metallurgical Society of AIME, 1981, pp. $159-69$.

7. B.R. Davies: "A Thermodynamic Study of Magnesium Chloride-Alkali Chloride Electrolytes For Use in Magnesium Production," PhD. Thesis, 1994, Queens University, Kingston, Ontario, Canada, pp. 3-4.

8. H.I. Kaplan: "Magnesium Supply and Demand - 1994," Presented at I.M.A.-52, San Francisco, May 23, 1995, (available from the International Magnesium Association).

9. M.C. Flemings, G.B. Kenney, D.R. Sadoway, J.P. Clark, and J. Szekely: "An Assessment of Magnesium Primary Production Technology," Report EX-76-A01-2295, Feb. 1981, U.S. Department of Energy.

10. L.M. Pidgeon: "New Methods for the Production of Magnesium," Transactions of the Canadian Institute of Mining and Metallurgy, Vol. 57, 1994, pp.16-34.

11. A. Froats: "Pidgeon Silicothermic Process in the 70's," Light Metals, 1980, pp. 969-79. 
12. J.R. Wynnyckyj and L.M. Pidgeon: "Equilibria in the Silicothermic Reduction of Calcined Dolomite," Metallurgical Transactions. Volume 2. April, 1971. pp. 979-86.

13. C. Faure and J. Marchal: "Magnesium by the Magnetherm Process," Journal of Metals, September, 1964, pp. 721-23.

14. F. Trocmé: "The Development of the "Magnetherm" Process," Light Metals, 1971, pp. 669-78.

15. F. Trocmé: "The Magnetherm process, Marignac, France," Advances in extractive metallurgy and refining, Proceedings of the I.M.M., London. October, 1971, M.J. Jones, ed., I.M.M., London, 1971, pp. 517-20.

16. M.P. Lugagne: "The Magnetherm Process for the Production of Magnesium," Erzmetall, Vol. 31, 1978, pp. 310-13.

17. C.L. Troutman and J.R. Chapman: "Northwest Alloys' Magnesium Operations at Addy, Washington," Light Metals, 1977, pp. 527.

18. T.A. Dungan: "Production of Magnesium by the Carbothermic Process at Permanente," Transactions of the AIME, Vol. 159, 1944, pp. 308-14.

19. E.F. Emlet: Principles of Magnesium Technology, Pergamon Press, Oxford, 1966, pp. 1-69.

20. Kh.L. Strelets: Electrolytic Production of Magnesium, translated by J. Schmorak, Isreal Program for Scientific Translation, Keterpress Enterprises, Jerusalem, 1977, also available as Report No. TT76-50003, U.S. Dept. of Commerce, N.T.I.S., Springfield, V.A..

21. N. Hoy-Peterson: "From Past to Future," Light Metal Age, August, 1990, pp. 12-16.

22. A. Von Zeerleder: Technology of Light Metals, Elsevier Publishing, New York, 1949, pp. 12-14.

23. J.F. Hunsberger: "Electrochemical Series," CRC Handbook of Chemistry and Physics, 59th Ed., R.C. Weast and M.J. Astle, eds., CRC Press, Boca Raton, Florida, 1978, pp. D-193-D-198. 
24. G.J. Janz, G.R. Lakshminarayanan, R.P.T. Tomkins and J. Wong: "Section 2. Surface Tension Data," Molten Salts: Volume 2. Nat. Stand. Ref. Data Ser., Nat. Bur. Stand. (U.S.), NSRDS-NBS 28, Washington, August. 1969, pp. 54-105.

25. A. Roine: HSC Chemistry for Windows Version 2.0, Outokumpu Research. Pori. Finland, 1994.

26. T. Rosenqvist: Principles of Extractive Metallurgy, 2nd Ed., McGraw-Hill, New York, 1983.

27. G.J. Janz, F.W. Dampier, G.R. Lakshminarayanan, P.K. Lorenz, and R.P.T. Tomkins: "Electrical Conductance, Density and Viscosity Data." Molten Salts: Volume 1, Nat. Stand. Ref. Data Ser., Nat. Bur. Stand. (U.S.), NSRDS-NBS 15, Washington, October, 1968, pp. 1-50.

28. N. Hoy-Peterson: "Some Aspects of the Electrolytic Production of Magnesium in I.G. Cells," Journal of Metals, April 1969, pp. 43-7.

29. D. Lea: "Magnesium Extraction Processes Today," Light Metal Age, August. 1982, pp. 29-31.

30. A.N. Petrunko and V.S. Lobanov: "New Devlopments in Producing Magnesium from Camallite," Light Metal Age, October, 1977, pp. 16-20.

31. "75 Years of Magnesium at Freeport," Light Metal Age, June, 1991, pp. 30-1.

32. O.G. Sivilotti: "Operating Performance of the Alcan Multipolar Magnesium Cell," Light Metals, 1988, pp. 817-22.

33. T. Noda: "Recent Progress in Ti Sponge Production in OTC (Part 2)," Light Metals, 1988, pp. 759-68.

34. N. Hoy-Peterson: "Magnesium Production at Porsgrunn, Norway," Light Metal Age, August, 1979, pp. 24-40.

35. "Anhydrous Magnesium Chloride By-Product Cuts Magnesium Production Cost at Norsk Hydro's New Porsgrunn, Norway, Plant," Light Metal Age, April, 1977, pp. 9-12.

36. G. Mezzetta: "Magnesium Plant Built on Environmental Respect." Light Metal Age, June, 1991, pp. 12-14. 
37. E.W. Barlow, S.C. Johnson and A. Sadan: "Solar Ponds as a Source of Magnesium for Electrolytic Cells," Light Metals, 1980. pp. 913-27.

38. H. Kaplan: "The Making of Magnesium. Magcorp"s Story," Light Metal Age. June, 1990, pp. 18-19.

39. B. Hawes: "At 34,500 tpy, Magcorp is third largest producer," Rocky Mountain P.AY DIRT, April, 1993, pp. 4A-8A.

40. “MagCan's New Magnesium Technology,” Light Metal Age. June. 1990. pp. 20.

41. L.E. Dastolfo: "Production of High Purity Magnesium Oxide by Selective Chlorination," Light Metals, 1991, pp.1181-88.

42. E. Aarebrot, R.E. Andresen, T. Østvold and H.A. Øye, Light Metals, Vol. 1, 1977, pp.491-512.

43. "Physical Constants of Inorganic Compounds." CRC Handbook of Chemistry and Physics, 59th Ed., R.C. Weast and M.J. Astle. eds., CRC Press, Boca Raton, Florida. 1978, pp. B-144.

44. G.H. Kucera and M.L. Saboungi: "Solubility of Magnesium Oxide in Calcium Oxide-Calcium Chloride Mixtures," Met. Trans. B, Vol. 7B, June 1976, pp. 213-15.

45. R.D. Toomey, B.R. Davis, R. Neelameggham and R. Keith: "Chlorination of Impure Magnesium Chloride Melt," U.S. Patent 4,248,839. Feb. 3, 1981.

46. R. Neelameggham, J.C. Priscu, and R.D. Toomey: "Molten Salt Electrostripping Cell and Method for Purifying Molten Salt Electrolytes," U.S. Patent 4,510,029, Apr. 9, 1985.

47. H.B. Schultes: "Baymag - high-purity magnesium oxide from natural magnesite," C.I.M. Bulletin, May, 1986, pp. 43-47.

48. The Economics of Magnesium Compounds 1987, Fifth Ed., Roskill Information Services, London, England, pp. 177-8.

49. D.V. Pruttskov, V.N. Devyatkin, S.M. Lupinos, Yu.M. Ryabukhin and V.G. Lysenko: "Mechanics of Magnesite Chlorination with a $\mathrm{Cl}_{2}+\mathrm{CO}$ Mixture," Tsvetnye Metally/ Soviet Journal of Non-Ferrous Metals, May 1986, pp. 52-6. 
50. "Physical Constants of Inorganic Compounds," CRC Handbook of Chemistry and Physics, 59th Ed., R.C. Weast and M.J. Astlc. eds., CRC Press. Boca Raton. Florida. 1978, pp. B-133.

51. W.C. Eister, W.R. Krumme: "An Evaluation of a SNIF Unit as an Inclusion Removal and Degassing Device." Light Metals. 1991, pp. 1171-6.

52. R.E. Miller, L.C. Blayden, M.J. Bruno and C.E. Brooks: "Inline Fumeless Metal Treatment," Light Metals, 1978, Vol. 2. pp. 491-505.

53. J. Bildstein, J. Lacroix, P. Netter, P. Prévost, and G. Zahorka: "Degassing Casting Alloy Ingots Using the Alpur System." Light Metals, 1987. pp. 431 1-5.

54. G.P. Wlaker, T.A. Zeliznak, and S.R. Sibley: "Practical Degassing with the R.D.U.," Light Metals, 1989, pp. 777-82.

55. G.I.F.S. - Gas Injection Fluxing System. Societe des Technologies de L'aluminum (S.T.A.S.) Ltd., Chicoutimi, sales literature. 1991.

56. M. Nilmani, P.K. Thay, and C.J. Simensen: "A Comparative Study of Impeller Performance," Light Metals, 1992, pp. 939-46.

57. J.C. Middleton: "Chapter 17, Gas-liquid dispersion and mixing," Mixing in the Process Industries, N. Harnby, M.F. Edwards and A.W. Nienow, eds., Butterworths, London, 1985, pp. 322-55.

58. R. Mann: "Gas-Liquid Sïrred Vessel Mixers: Towards a Unified Theory Based on Networks-of-Zones," Chem. Eng. Res. Des., Vol. 64, January 1986, pp.23-34.

59. R.E. Treybal: “ Chapter 6 Equipment for Gas-Liquid Operation," Mass-Transfer Operations, 3rd. Ed., McGraw-Hill, New York, 1980, pp. 139-219.

60. M. Greaves and M. Barigou: "Estimation of Gas Hold-up and Impeller Power in a Stirred Vessel Reactor," Fluid Mixing III, Univeristy of Bradford, September 810, 1987, Instution of Chemical Engineers, Symposium Series No. 108, 1987. pp. 235-55.

61. C.M. Cooper, G.A. Fernstrom and S.A. Miller: "Performance of Agitated GasLiquid Contactors," Industrial and Engineering Chemistry, Vol. 36. No. 6. 1944. pp.504-9. 
62. K. Van't Riet: "Review of Measuring Methods and Results in Non-viscous GasLiquid Mass Transfer in Stirred Vessels." Ind. Eng. Process Des. Dev., Vol. 18. No. 3.. 1979. pp.357-64.

63. J.G. Stevens and H. Yu: "A Computer Model of a Stirred Tank Reactor in Trace Alkaline Elements Removal From Aluminum Melt - The Alcoa 622 Process." Light Metals, 1986, p.837.

64. F.A. Holland and F.S. Chapman: Liquid Mixing and Processing in Stirred Tanks. Reinhold Publishing. New York, Chapman and Hall Ltd.. London. 1966. pp. 1-49.

65. R.L. Bates, P.L. Fondy and J.G. Fenic: "Chapter 3 Impeller Characteristics and Power," Mixing Theory and Practice, Vol. I, V.W. Uhl and J. B. Gray, eds., Academic Press, New York, 1966, pp. 111-78.

66. R.L. Bates, P.L. Fondy and R.R. Corpstein: "An Examination of Some Geometric Parameters of Impeller Power." I\&EC Process Design and Development. Vol.2, No. 4, October 1963, 310-14.

67. J.B. Joshi, A.B. Pandit and M.M. Sharma: "Mechanically Agitated Gas-Liquid Reactors," Chemical Engineering Science, Vol. 37, No. 6, Pregamon Press, Ltd.. Great Britain, 1982, pp. 813-44.

68. K. Koloini, I. Plazl and M. Zumer: "Power Consumption, Gas Hold-up and Interfacial Area in Aerated Non-Newtonian Suspensions in Stirred Tanks of Square Cross-Section," Chem. Eng. Res. Des., Vol. 67, September 1989, pp 526-36.

69. J.H. Rushton and J.J. Bimbinet: "Holdup and Flooding in Air Liquid Mixing." The Canadian Journal of Chemical Engineering, Vol. 46, February, 1969, pp.16-21.

70. C.M. Chapman, A.W. Nienow, M. Cooke and J.C. Middleton: "Particle-GasLiquid Mixing in Stirred Vessels, Part II: Gas-Liquid Mixing," Chem. Eng. Res. Des., Vol. 61, March 1983, pp. 82-95.

71. A.W. Nienow, M. Konno and W. Bujalski: "Studies on Three-Phase Mixing: A Review and Recent Results," Chem. Eng. Res. Des., Vol. 64, January 1986, pp. 35-42.

72. C.M. Chapman, A.W. Nienow, M. Cooke and J.C. Middleton: "Particle-GasLiquid Mixing in Stirred Vessels, Part III: Three Phase Mixing," Chem. Eng. Res. Des., Vol. 61, May 1983, pp. 167-81. 
73. J.Y. Oldshue: "Chapter 5, Solids Suspension," Fluid Mixing Technology. McGraw Hill. New York. 1983, pp. 94-124.

74. A.W. Nienow: "Chapter 16. The Suspension of Solid Particles," Mixing in the Process Industries, N. Harnby, M.F. Edwards and A.W. Nienow, eds., Butterworths, London. 1985, pp. 297-321.

75. R. King: "Chapter 14, Mechanical Aspects of Mixing." Mixing in the Process Industries, N. Harnby, M.F. Edwards and A.W. Nienow, eds., Butterworths, London, 1985, pp. 251-84.

76. E.E. Chin: Unpublished Research, Noranda Technology Centre, 1989.

77. M.W. Kennedy, J.G. Lenz and E.E. Chin: "Rotary Gas Injector," Canadian Patent Application No. 2.073,908, July 16. 1992.

78. "Graphite Rod and Plate Stock, Carbon Products." The Carbide/Graphite Group Inc. Publication. C5-3001, Rev. 4/91 5M. U.S.A.

79. “Technical Information," Union Carbide, Carbon Products Division, September, $15,1987$.

80. "Physical Constants of Inorganic Compounds," CRC Handbook of Chemistry and Physics, 59th Ed., R.C. Weast and M.J. Astle, eds., CRC Press, Boca Raton, Florida, 1978, pp. B-107.

81. "Volumetric Determination of Magnesium Oxide in Magnesium Chloride Powder." Centre de Technologie Noranda. Analytical Procedure, April 27, 1989.

82. D. Dumas, K. Grjotheim, B. Högdahl and H.A. Oye: "Theory of Oscillating Bodies and its Utilization for Determination of High-temperature Viscosities," Acta Chemica Scandinavica, 24, 1970, No. 2, pp. 510-30.

83. P.X. Kypmaeb, H.N. Ymeb: Tsvetnye Metally/ Soviet Journal of Non-Ferrous Metals, Vol. 15 (1), 1972, pp. 47-9.

84. A.A. Maurits: "Viscosity of Salt Melts in the System $\mathrm{KCl}-\mathrm{NaCl}-\mathrm{CaCl}_{2}-\mathrm{MgCl}_{2}$ with the Weight Ratio $\mathrm{KCl}: \mathrm{NaCl}=8: 1$, Journal of Applied Chemistry of the U.S.S.R. Vol. 40 (1) 1967.pp. $41-46$. 
85. R.N. Kacker, "Taguchi Methods," Handbook of Statistical Methods for Engineers and Scientists, Chapter 19, H.M. Wadsworth, eds., McGraw-Hill, New York, 1990, pp. 19.21. 